LA-14181-PR

Approved for public release;

distribution is unlimited.

\title{
Radionuclide Concentrations in
}

Soils and Vegetation at

Low-Level Radioactive Waste

Disposal Area G during 2004
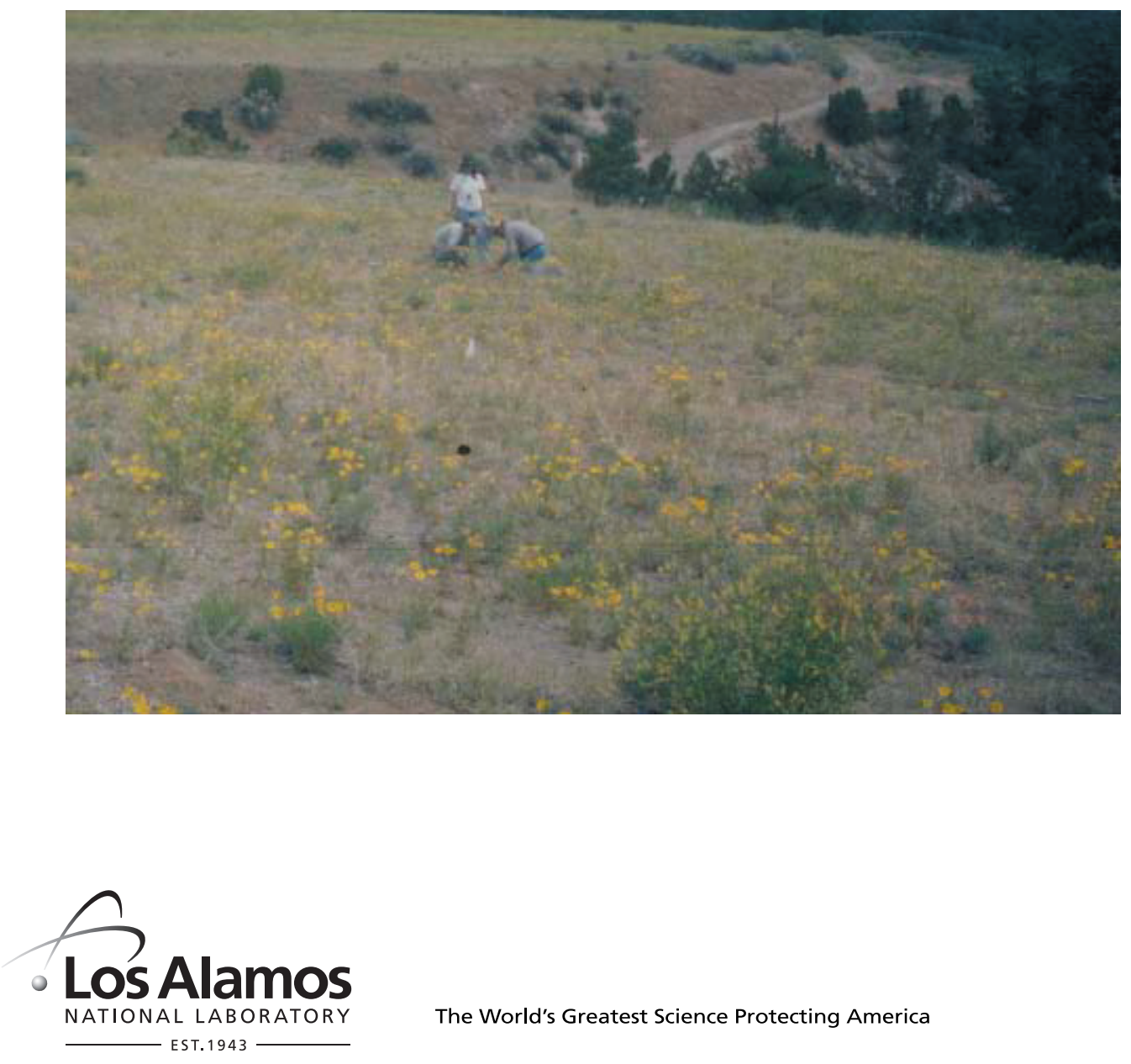

The World's Greatest Science Protecting America 
The three most recent reports in this unclassified series are LA-13942-PR, LA-14095-PR, and LA-14108-PR.

Edited by Hector Hinojosa, Group IM-1

Prepared by Teresa Hiteman, Group RRES-ECO

Cover photo: Meteorology and Air Quality group personnel collect soil and plant samples over the southeastern portions of Pits 17 and 18 at Area G.

Los Alamos National Laboratory, an affirmative action/equal opportunity employer, is operated by the University of California for the United States Department of Energy under contract W-7405-ENG-36.

This report was prepared as an account of work sponsored by an agency of the United States Government. Neither the Regents of the University of California, the United States Government nor any agency thereof, nor any of their employees make any warranty, express or implied, or assume any legal liability or responsibility for the accuracy, completeness, or usefulness of any information, apparatus, product, or process disclosed, or represent that its use would not infringe privately owned rights. Reference herein to any specific commercial product, process, or service by trade name, trademark, manufacturer, or otherwise does not necessarily constitute or imply its endorsement, recommendation, or favoring by the Regents of the University of California, the United States Government, or any agency thereof. The views and opinions of authors expressed herein do not necessarily state or reflect those of the Regents of the University of California, the United States Government, or any agency thereof. Los Alamos National Laboratory strongly supports academic freedom and a researcher's right to publish; as an institution, however, the Laboratory does not endorse the viewpoint of a publication or guarantee its technical correctness. 
LA-14181-PR

Issued: November 2004

Radionuclide Concentrations in

Soils and Vegetation at

Low-Level Radioactive Waste

Disposal Area G during 2004

P.R. Fresquez

E.A. Lopez 



\title{
RADIONUCLIDE CONCENTRATIONS IN SOILS AND VEGETATION AT LOW-LEVEL RADIOACTIVE WASTE DISPOSAL AREA G DURING 2004
}

\author{
P.R. Fresquez and E.A. Lopez
}

\begin{abstract}
Soil samples were collected at 15 locations and unwashed overstory and understory vegetation samples were collected at nine locations within and around the perimeter of Area G, the primary disposal facility for low-level radioactive solid waste at Los Alamos National Laboratory (LANL). These samples were analyzed for ${ }^{3} \mathrm{H},{ }^{238} \mathrm{Pu}$, ${ }^{239,240} \mathrm{Pu},{ }^{90} \mathrm{Sr},{ }^{241} \mathrm{Am},{ }^{137} \mathrm{Cs},{ }^{234} \mathrm{U},{ }^{235} \mathrm{U}$, and ${ }^{238} \mathrm{U}$. Soil samples collected at Area G contained detectable concentrations of ${ }^{3} \mathbf{H}(27 \%),{ }^{239,240} \mathrm{Pu}$ $(60 \%),{ }^{238} \mathrm{Pu}(40 \%)$, and ${ }^{241} \mathrm{Am}(47 \%)$ above regional statistical reference levels (RSRLs). In contrast, the levels of ${ }^{137} \mathrm{Cs},{ }^{90} \mathrm{Sr}$, and $\mathrm{U}$ in all of the soil samples at Area $G$ were either nondetectable or within RSRLs. The highest levels of ${ }^{3} \mathrm{H}$ in soils were detected in the southwestern portion of Area $G$ near the ${ }^{3} \mathbf{H}$ shafts, whereas the highest concentrations of the $P u$ isotopes were detected in the northern and northeastern portions. All concentrations of ${ }^{3} \mathrm{H}$ and $\mathrm{Pu}$ in soils, however, were far below LANL screening action levels. As for vegetation, most radionuclides in/on plants were either nondetectable or within RSRLs. The exceptions were ${ }^{3} \mathrm{H}$ in overstory and some understory vegetation, particularly in the southwestern portion of Area G, which correlated very well with the soils data in that area. Also, there was some foliar contamination from ${ }^{241} \mathrm{Am}$ and $\mathrm{Pu}$ isotopes in/on a few plant samples-the highest concentrations occurring in the northern section of Area G.
\end{abstract}

\section{INTRODUCTION}

Solid radioactive wastes have been disposed of by burial at Los Alamos National Laboratory (LANL) since the early 1940s (Purtymun et al., 1980). Area G is a 25.5hectare (63-acre) low-level radioactive waste processing and disposal area located on the east end of Mesa del Buey at Technical Area (TA) 54 (Figure 1). Area G was established in 1957 and is the Laboratory's primary radioactive solid waste burial and storage site (Soholt, 1990). Wastes for disposal include contaminated equipment, paper, plastics, clothing, building materials, soils, and process wastes and are placed in pits, trenches, or shafts and then covered with fill material (Hansen et al., 1980). ${ }^{3} \mathrm{H}, \mathrm{U},{ }^{238} \mathrm{Pu},{ }^{239,240} \mathrm{Pu}$, and a variety of fission and activation products are the main isotopes in waste materials deposited at Area G (U.S. DOE, 1979). 


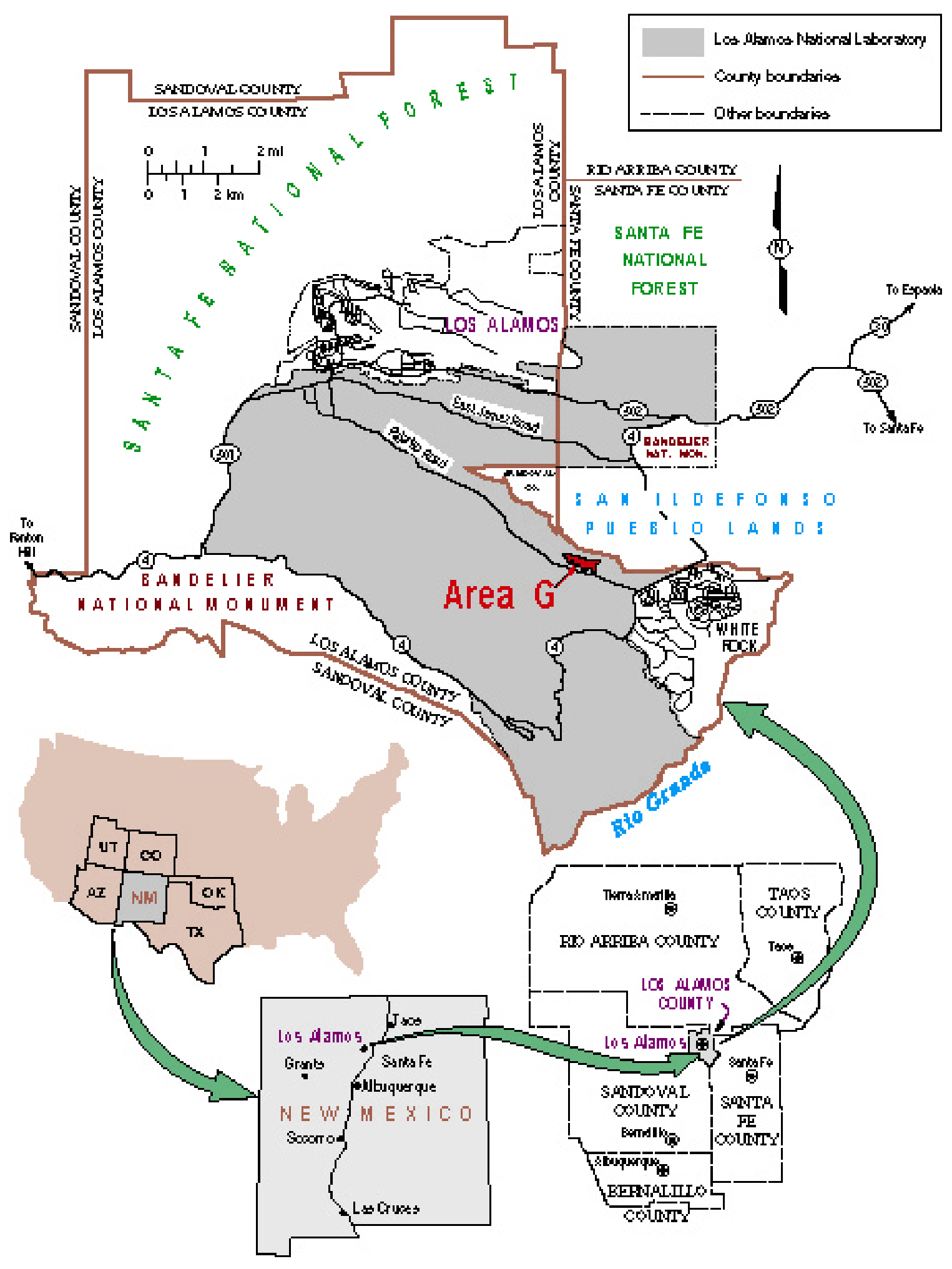

Figure 1. The location of Area G at Los Alamos National Laboratory. 
As part of the Environmental Surveillance Program at LANL, samples of soils and vegetation have been collected within and around the perimeter of Area G to monitor and assess the site's impact on the surrounding environment (Lopez, 2002). A soil sampling program is the most direct means of estimating the types, concentrations, and distribution of radionuclides in the environment within and around nuclear facilities (Fresquez et al., 1996). Soil provides an integrating medium, or reservoir, that can account for contaminants released to the atmosphere, either directly from gaseous effluents, such as air stack emissions, or indirectly from the resuspension of on-site contamination (fugitive dust) (Healy, 1977). Subsequently, the knowledge gained from the radiological surveillance of soil is critical to provide information about potential exposure by way of several pathways that include soil ingestion, consumption of food crops, resuspension of radionuclides into the air, and contamination of groundwater (Hakonson et al., 1981). The uptake of radionuclides by vegetation may also give some insight into surface (Hansen et al., 1980) and subsurface (Wenzel et al., 1987) pathways of contaminants to receptors from waste disposal areas. Trees, in particular, have been

shown to be excellent indicators of subterranean ${ }^{3} \mathrm{H}$ migration from low-level radioactive waste disposal sites (Rickard and Kirby 1987, Fresquez et al., 2003a).

The objective of this program is to compare radionuclides in soils and vegetation collected from within and around Area G with similar media collected from regional background areas in an effort to determine impacts to human health and the environment, if any.

\section{METHODS}

In 2004, the Soils, Foodstuffs, and Biota Environmental Surveillance Team of LANL’s Meteorology and Air Quality Group collected 15 soil surface samples and nine overstory and understory vegetation samples at locations within and around Area $G$ at TA-54 (Figure 2 and Table 1 describes each site in more detail). Other soil and vegetation materials were collected west of Area $G$ in the proposed expansion area (site identified as 8 in Figure 2 and Table 1); this site has been sampled for some time now for the purpose of gaining preoperational baseline data. 


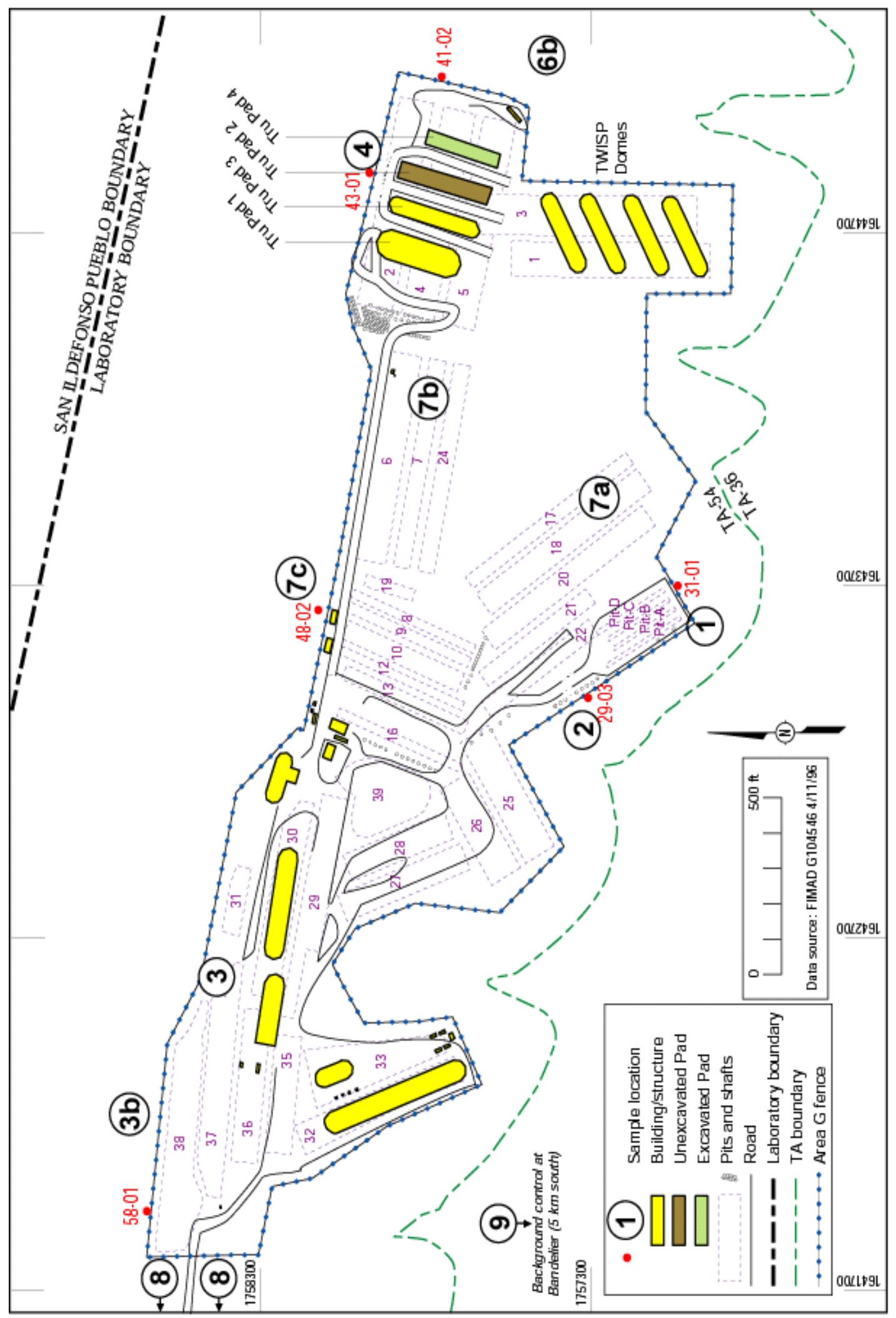

Figure 2. Site/sample locations of soils and vegetation at Area G. (Site \#8 is located farther west and Site \#9 is located farther south than what is shown here.) 
Table 1. Sampling Locations Used in 2004 and shown on Figure 2.

\begin{tabular}{c|l}
$\begin{array}{c}\text { Location } \\
\text { Number }\end{array}$ & \multicolumn{1}{c}{ Description } \\
\hline $\mathbf{1}$ & \multicolumn{1}{c}{ Area G sampling sites } \\
\hline $\mathbf{2}$ & South of ${ }^{3}$ H shafts immediately outside the Area G fence \\
\hline $\mathbf{3}$ & West of the high-level ${ }^{3}$ H shafts immediately outside the Area G fence \\
\hline $\mathbf{3 b}$ & East of Pit 38 (inside the Area G fence) \\
\hline $\mathbf{4}$ & North of Pit 38 outside the Area G fence \\
\hline $\mathbf{6 b}$ & Outside the Area G fence north of the TRU Waste Pads 2 and 4 \\
\hline $\mathbf{7 a}$ & Southeast of TRU Waste Pad 4 outside Area G fence \\
\hline $\mathbf{7 b}$ & East end of Pit 7 (inside the Area G fence) \\
\hline $\mathbf{7 c}$ & North of Pit 8 outside the Area G fence \\
\hline $\mathbf{G - 2 9 - 0 3}$ & Southwest of Pit 22 (outside the Area G fence) \\
\hline $\mathbf{G - 3 1 - 0 1}$ & Southeast of Disposal Trench C (outside the Area G fence) \\
\hline $\mathbf{G - 4 1 - 0 2}$ & $\begin{array}{l}\text { East of the eastern end of Pit 2 and TRU Pad 4 (outside the Area G } \\
\text { fence) }\end{array}$ \\
\hline $\mathbf{G - 4 3 - 0 1}$ & North of TRU Pad 2 (outside the Area G fence) \\
\hline $\mathbf{G - 4 8 - 0 2}$ & North of Pit 10 (outside the Area G fence) \\
\hline $\mathbf{G - 5 8 - 0 1}$ & North of western end of Pit 38 near gate (outside the Area G fence) \\
\hline $\mathbf{8}$ & \multicolumn{1}{c}{ Expansion Area } \\
\hline & $\begin{array}{l}\text { Proposed expansion area is one-half mile west of the entrance gate to } \\
\text { Area G }\end{array}$ \\
\hline
\end{tabular}

\section{a. Soil Sampling}

Over the years, two soil-sampling strategies have been utilized at Area $G$ in an effort to determine the pathway contributions of surface water runoff and fugitive dust. The first soil sampling strategy (1980 to present) involves collecting grab samples along the perimeter fence line and is focused on the possibility of contaminated sediment movement through surface-water runoff out of Area G (Conrad et al., 1995). The locations chosen represent the most sensitive to possible contaminant migration. The second soil sampling strategy (1996 to present) involved collecting composite samples over a larger area within and outside the perimeter of Area $G$ to determine the amount of contaminants as a result of fugitive dust (Fresquez et al., 1997). The methods of collection of the two soil sampling strategies are the following: 
1. Samples prefixed with the letter $G$ were collected as a grab sample from the top $15 \mathrm{~cm}$ (6 in.) of the soil surface with either a stainless steel or a disposable polystyrene scoop. These samples were placed into $500-\mathrm{mL}$ (17 oz.) poly bottles.

2. Samples prefixed with a number were collected from the surface with a stainless steel soil ring $10 \mathrm{~cm}$ (4 in.) in diameter driven $5 \mathrm{~cm}$ (2 in.) into the soil (ASTM, 1990). Samples were collected from the center and corners of a square plot of 10 $\mathrm{m}$ (33 ft) per side. The five subsamples were combined and mixed thoroughly in a 11.4-L (three-gallon) Ziploc ${ }^{\circledR}$ bag, and a subsample from the composite was placed in a $500-\mathrm{mL}$ (17 oz.) poly bottle.

All soil samples were submitted under full chain-of-custody to Paragon Analytics, Inc., for analysis of ${ }^{3} \mathrm{H},{ }^{238} \mathrm{Pu},{ }^{239,240} \mathrm{Pu},{ }^{137} \mathrm{Cs},{ }^{234} \mathrm{U},{ }^{235} \mathrm{U},{ }^{238} \mathrm{U}$, ${ }^{90} \mathrm{Sr}$, and ${ }^{241} \mathrm{Am}$. All quality assurance/quality control requirements were met by Paragon Analytics, Inc. All methods of radiochemical analyses have been described previously (Fresquez et al., 1997; Childs and Conrad, 1997) and the methods for estimating Total Propagated Analytical Uncertainty (TPU) for all radiometric analyses were described in detail previously (Nyhan et al., 2002). Radionuclide results were reported in $\mathrm{pCi} / \mathrm{mL}$ of soil moisture for ${ }^{3} \mathrm{H}$ and pCi/g dry soil for all the other isotopes.

\section{b. Plant Sampling}

Samples of overstory vegetation, mostly piñon and juniper trees, and understory vegetation, mostly grasses and forbs, were collected. Overstory and understory samples were collected at all sampling locations from the same 10- by $10-\mathrm{m}$ plots as the soil composite samples. Overstory samples were mainly from piñon pine because piñon pine is the prevalent tree in the vicinity of Area G (Tierney and Foxx, 1982). Samples of the overstory consisted of the tips of tree shoots approximately 2.5 to $5.1 \mathrm{~cm}$ (1 to $2 \mathrm{in}$.) in length, which were collected at a height of 1.3 to $1.6 \mathrm{~m}$ (4 to $5 \mathrm{ft}$ ), whereas samples of the understory plants consisted of clippings of the top growth cut at the soil level.

Personnel collecting samples wore plastic gloves and used clean shears to clip vegetation; gloves and shears were decontaminated (washed with soap and water) between sampling locations. Vegetation clippings ranged from 0.9 to $1.4 \mathrm{~kg}$ (2 to $3 \mathrm{lb}$ ) of composited material, which was placed in labeled double-bagged Ziploc ${ }^{\circledR}$ plastic bags 
and transported to the laboratory in a locked ice chest. Each sample was divided into two subsets to provide enough material for ${ }^{3} \mathrm{H}$ analysis and for the other radionuclides. Samples were not washed and thus represent the total concentration of radionuclides deposited on the plant surfaces by rainsplash and/or airborne deposition as well as radionuclides taken up by plant roots. The total radionuclide concentration is a realistic measure of the amount available to receptors that consume the plants at Area G.

Part of the vegetation sample was subsampled for ${ }^{3} \mathrm{H}$ analysis. The subsamples were placed in glass beakers to collect distillate water (Salazar, 1984). The remaining portion of each subsample was placed in a 1-L (34 oz.) glass beaker and slowly ashed at $500^{\circ} \mathrm{C}\left(932^{\circ} \mathrm{F}\right)$ for $120 \mathrm{~h}$. The ashed sample was pulverized and homogenized, then transferred to labeled 500-mL (17 oz.) poly bottles and submitted with the distillate samples under full chain-of-custody to Paragon Analytics, Inc., for the analysis of ${ }^{3} \mathrm{H}$, ${ }^{238} \mathrm{Pu},{ }^{239,240} \mathrm{Pu},{ }^{137} \mathrm{Cs},{ }^{234} \mathrm{U},{ }^{235} \mathrm{U},{ }^{238} \mathrm{U},{ }^{241} \mathrm{Am}$, and ${ }^{90} \mathrm{Sr}$; all quality assurance/quality control requirements were met. All methods of radiochemical analyses have been described previously (Fresquez et al., 1996). Radionuclide results were reported in $\mathrm{pCi} / \mathrm{mL}$ of tissue moisture for ${ }^{3} \mathrm{H}$ and $\mathrm{pCi} / \mathrm{g}$ ash for all the other isotopes. Results reported in grams of ash are usually two to four orders of magnitude greater than live (wet) weight.

\section{c. Determining the Composition of Uranium}

To determine the source of $U$ in soils and vegetation at the 99\% confidence level, the $U$ isotopic distribution of ${ }^{234} U$ and ${ }^{238} U$, which for naturally occurring $U$ is one, was assessed using the following steps: (1) the difference between ${ }^{234} U$ and ${ }^{238} \mathrm{U}$ was calculated, (2) the squares of their uncertainties were summed and then the square root of this number was taken, (3) the ${ }^{234} \mathrm{U}$ and ${ }^{238} \mathrm{U}$ difference was divided by the pooled square root, (4) if the result was greater than 3 , then it was observed whether the ${ }^{234} \mathrm{U}$ value or the ${ }^{238} U$ value was larger, (5) if the ${ }^{234} U$ value was larger, then excess enriched $U$ was indicated. Conversely, if the ${ }^{238} \mathrm{U}$ value was larger, then excess depleted $U$ was indicated. 


\section{RESULTS}

\section{a. Radionuclide Concentrations in Soils}

Results of radionuclide concentrations in soils are given in Table 2. The chain-ofcustody records and actual Paragon Analytics, Inc., analytical reports are included in Appendix A for reference.

Concentrations of ${ }^{3} \mathrm{H}$ were detected (results greater than three times the TPU; the 99\% confidence level) above the regional statistical reference level (RSRL) in only four of the 15 soil samples (27\%); these results are down from 87\% detected last year and the amounts are far lower than past years (Nyhan et al., 2004; Fresquez et al., 2004), particularly in the south and southwestern portions of Area $\mathrm{G}$ were the ${ }^{3} \mathrm{H}$ shafts are located. The RSRL is the mean plus three standard deviations (99\% confidence level) of regional background sample concentrations collected from 1999 through 2003 (Fresquez, 2004). The concentrations of ${ }^{239,240} \mathrm{Pu}$ in most soil samples were at higher levels than the RSRL (60\%) and correlate very well with past results. Other radionuclides that were detected above RSRLs in soil samples were ${ }^{241} \mathrm{Am}$ at $47 \%$ (down from $53 \%$ last year), and ${ }^{238} \mathrm{Pu}$ at $40 \%$ (down from $60 \%$ last year) of the samples collected. None of the assays for soil ${ }^{90} \mathrm{Sr},{ }^{137} \mathrm{Cs}$, or $\mathrm{U}$ isotopes were higher than the corresponding RSRLs, and the source of uranium at all sampling sites was natural. All radionuclides that were higher than the RSRL were still far below the screening action levels (SALs) for soils. SALs, established by the Environmental Restoration Project at Los Alamos (ER, 2001), are levels of radionuclides that limit the potential radiation dose to humans to less than 15 $\mathrm{mrem} / \mathrm{yr}$.

\section{b. Radionuclide Concentrations in Plants}

Table 3 shows radionuclide concentrations in unwashed overstory vegetation collected from within and around Area G during the 2004 growing season. The Paragon Analytics, Inc., analytical reports are included in Appendix B for reference. 
Table 2. Radionuclide Concentrations (TPU, 99\% confidence level) in Soils collected from Area G in 2004. (Bold values are greater than the TPU and RSRL).

\begin{tabular}{|c|c|c|c|c|c|c|c|c|c|}
\hline Location & $\begin{array}{c}{ }^{3} \mathrm{H} \\
(\mathrm{pC} \mathbf{i} / \mathrm{mL})\end{array}$ & $\begin{array}{c}{ }^{241} \mathrm{Am} \\
\text { (pCi/g dry) }\end{array}$ & $\begin{array}{c}{ }^{137} \mathrm{Cs} \\
\text { (pCi/g dry) }\end{array}$ & $\begin{array}{c}{ }^{238} \mathrm{Pu} \\
\text { (pCi/g dry) }\end{array}$ & $\begin{array}{c}{ }^{239,240} \mathrm{Pu} \\
\text { (pCi/g dry) }\end{array}$ & $\begin{array}{c}{ }^{90} \mathrm{Sr} \\
\text { (pCi/g dry) }\end{array}$ & $\begin{array}{c}{ }^{234} \mathrm{U} \\
\text { (pCi/g dry) }\end{array}$ & $\begin{array}{c}{ }^{235} \mathrm{U} \\
\text { (pCi/g dry) }\end{array}$ & $\begin{array}{c}{ }^{238} \mathrm{U} \\
\text { (pCi/g dry) }\end{array}$ \\
\hline 1 & $\begin{array}{c}4.5 \\
(1.2)\end{array}$ & $\begin{array}{c}0.014 \\
(0.011)\end{array}$ & $\begin{array}{c}0.30 \\
(0.18)\end{array}$ & $\begin{array}{c}0.0081 \\
(0.0092)\end{array}$ & $\begin{array}{c}0.021 \\
(0.014)\end{array}$ & $\begin{array}{c}0.15 \\
(0.15)\end{array}$ & $\begin{array}{c}0.87 \\
(0.26)\end{array}$ & $\begin{array}{c}0.037 \\
(0.038)\end{array}$ & $\begin{array}{c}0.81 \\
(0.24)\end{array}$ \\
\hline 2 & $\begin{array}{l}58 \\
(13)\end{array}$ & $\begin{array}{c}0.0069 \\
(0.0065)\end{array}$ & $\begin{array}{c}0.38 \\
(0.23)\end{array}$ & $\begin{array}{c}0.0063 \\
(0.0065)\end{array}$ & $\begin{array}{c}0.023 \\
(0.014)\end{array}$ & $\begin{array}{r}0.0020 \\
(0.14)\end{array}$ & $\begin{array}{c}1.1 \\
(0.32)\end{array}$ & $\begin{array}{c}0.035 \\
(0.035)\end{array}$ & $\begin{array}{c}1.2 \\
(0.33)\end{array}$ \\
\hline 3 & $\begin{array}{c}0.45 \\
(0.47)\end{array}$ & $\begin{array}{c}0.0076 \\
(0.0065)\end{array}$ & $\begin{array}{l}0.21 \\
(0.18)\end{array}$ & $\begin{array}{c}0.0069 \\
(0.0084)\end{array}$ & $\begin{array}{c}0.034 \\
(0.018)\end{array}$ & $\begin{array}{l}0.047 \\
(0.14)\end{array}$ & $\begin{array}{c}0.92 \\
(0.27)\end{array}$ & $\begin{array}{c}0.050 \\
(0.044)\end{array}$ & $\begin{array}{c}0.93 \\
(0.27)\end{array}$ \\
\hline $3 b$ & $\begin{array}{c}0.20 \\
(0.45)\end{array}$ & $\begin{array}{c}0.0080 \\
(0.0071)\end{array}$ & $\begin{array}{c}0.45 \\
(0.23)\end{array}$ & $\begin{array}{c}0.0058 \\
(0.0075)\end{array}$ & $\begin{array}{c}0.020 \\
(0.014)\end{array}$ & $\begin{array}{l}-0.11 \\
(0.15)\end{array}$ & $\begin{array}{c}1.0 \\
(0.30)\end{array}$ & $\begin{array}{c}0.061 \\
(0.050)\end{array}$ & $\begin{array}{c}0.96 \\
(0.29)\end{array}$ \\
\hline 4 & $\begin{array}{c}0.14 \\
(0.47)\end{array}$ & $\begin{array}{c}0.17 \\
(0.051)\end{array}$ & $\begin{array}{c}0.54 \\
(0.26)\end{array}$ & $\begin{array}{c}0.14 \\
(0.045)\end{array}$ & $\begin{array}{c}0.32 \\
(0.086)\end{array}$ & $\begin{array}{c}0.20 \\
(0.18)\end{array}$ & $\begin{array}{c}1.1 \\
(0.33)\end{array}$ & $\begin{array}{c}0.052 \\
(0.044)\end{array}$ & $\begin{array}{c}1.2 \\
(0.35)\end{array}$ \\
\hline $6 b$ & $\begin{array}{l}0.050 \\
(0.44)\end{array}$ & $\begin{array}{c}0.029 \\
(0.014)\end{array}$ & $\begin{array}{c}0.28 \\
(0.18)\end{array}$ & $\begin{array}{c}0.0069 \\
(0.0078)\end{array}$ & $\begin{array}{c}0.12 \\
(0.039)\end{array}$ & $\begin{array}{r}-0.030 \\
(0.15)\end{array}$ & $\begin{array}{l}0.79 \\
(0.24)\end{array}$ & $\begin{array}{c}0.028 \\
(0.033)\end{array}$ & $\begin{array}{l}0.90 \\
(0.27)\end{array}$ \\
\hline $7 a$ & $\begin{array}{c}0.58 \\
(0.48)\end{array}$ & $\begin{array}{c}0.0061 \\
(0.0063)\end{array}$ & $\begin{array}{l}0.010 \\
(0.15)\end{array}$ & $\begin{array}{c}0.020 \\
(0.012)\end{array}$ & $\begin{array}{c}0.19 \\
(0.012)\end{array}$ & $\begin{array}{l}-0.10 \\
(0.15)\end{array}$ & $\begin{array}{c}0.92 \\
(0.27)\end{array}$ & $\begin{array}{c}0.050 \\
(0.044)\end{array}$ & $\begin{array}{c}1.1 \\
(0.33)\end{array}$ \\
\hline $7 b$ & $\begin{array}{c}0.64 \\
(0.48)\end{array}$ & $\begin{array}{c}0.016 \\
(0.011)\end{array}$ & $\begin{array}{l}-0.010 \\
(0.15)\end{array}$ & $\begin{array}{c}0.0064 \\
(0.0072)\end{array}$ & $\begin{array}{c}0.089 \\
(0.032)\end{array}$ & $\begin{array}{r}-0.045 \\
(0.15)\end{array}$ & $\begin{array}{c}0.88 \\
(0.26)\end{array}$ & $\begin{array}{c}0.041 \\
(0.038)\end{array}$ & $\begin{array}{c}0.89 \\
(0.27)\end{array}$ \\
\hline $7 c$ & $\begin{array}{l}0.49 \\
(0.47)\end{array}$ & $\begin{array}{c}0.11 \\
(0.035)\end{array}$ & $\begin{array}{c}0.67 \\
(0.26)\end{array}$ & $\begin{array}{c}0.059 \\
(0.024)\end{array}$ & $\begin{array}{c}0.31 \\
(0.084)\end{array}$ & $\begin{array}{r}-0.040 \\
(0.17)\end{array}$ & $\begin{array}{c}1.1 \\
(0.32)\end{array}$ & $\begin{array}{c}0.049 \\
(0.042)\end{array}$ & $\begin{array}{c}1.0 \\
(0.29)\end{array}$ \\
\hline G-29-03 & $\begin{array}{l}159 \\
(36)\end{array}$ & $\begin{array}{c}0.0030 \\
(0.0045)\end{array}$ & $\begin{array}{c}0.16 \\
(0.17)\end{array}$ & $\begin{array}{c}0.0015 \\
(0.0056)\end{array}$ & $\begin{array}{c}0.0068 \\
(0.0084)\end{array}$ & $\begin{array}{l}0.050 \\
(0.18)\end{array}$ & $\begin{array}{c}0.86 \\
(0.26)\end{array}$ & $\begin{array}{c}0.035 \\
(0.035)\end{array}$ & $\begin{array}{c}0.91 \\
(0.27)\end{array}$ \\
\hline G-31-01 & $\begin{array}{c}17 \\
(3.9)\end{array}$ & $\begin{array}{c}0.0064 \\
(0.0069)\end{array}$ & $\begin{array}{l}0.099 \\
(0.14)\end{array}$ & $\begin{array}{c}0.0015 \\
(0.0065)\end{array}$ & $\begin{array}{c}0.0068 \\
(0.0089)\end{array}$ & $\begin{array}{l}0.070 \\
(0.17)\end{array}$ & $\begin{array}{l}0.80 \\
(0.24)\end{array}$ & $\begin{array}{c}0.031 \\
(0.030)\end{array}$ & $\begin{array}{c}0.87 \\
(0.26)\end{array}$ \\
\hline G-41-02 & $\begin{array}{c}0.52 \\
(0.47)\end{array}$ & $\begin{array}{c}0.051 \\
(0.023)\end{array}$ & $\begin{array}{c}0.20 \\
(0.15)\end{array}$ & $\begin{array}{c}0.33 \\
(0.090)\end{array}$ & $\begin{array}{c}0.14 \\
(0.045)\end{array}$ & $\begin{array}{l}0.10 \\
(0.14)\end{array}$ & $\begin{array}{l}0.87 \\
(0.26)\end{array}$ & $\begin{array}{c}0.049 \\
(0.039)\end{array}$ & $\begin{array}{c}0.89 \\
(0.26)\end{array}$ \\
\hline G-43-01 & $\begin{array}{c}0.27 \\
(0.45)\end{array}$ & $\begin{array}{c}0.060 \\
(0.024)\end{array}$ & $\begin{array}{c}0.35 \\
(0.21)\end{array}$ & $\begin{array}{c}0.056 \\
(0.024)\end{array}$ & $\begin{array}{c}0.19 \\
(0.057)\end{array}$ & $\begin{array}{c}0.40 \\
(0.18)\end{array}$ & $\begin{array}{c}1.0 \\
(0.30)\end{array}$ & $\begin{array}{c}0.050 \\
(0.042)\end{array}$ & $\begin{array}{c}1.1 \\
(0.32)\end{array}$ \\
\hline G-48-02 & $\begin{array}{l}0.58 \\
(0.48)\end{array}$ & $\begin{array}{c}0.13 \\
(0.042)\end{array}$ & $\begin{array}{l}0.40 \\
(0.20)\end{array}$ & $\begin{array}{c}0.094 \\
(0.033)\end{array}$ & $\begin{array}{c}0.64 \\
(0.17)\end{array}$ & $\begin{array}{l}0.092 \\
(0.11)\end{array}$ & $\begin{array}{c}1.0 \\
(0.29)\end{array}$ & $\begin{array}{c}0.042 \\
(0.038)\end{array}$ & $\begin{array}{c}1.0 \\
(0.29)\end{array}$ \\
\hline
\end{tabular}


Table 2 (cont.)

\begin{tabular}{|c|c|c|c|c|c|c|c|c|c|}
\hline Location & $\begin{array}{c}{ }^{3} \mathrm{H} \\
(\mathrm{pCi} / \mathrm{mL})\end{array}$ & $\begin{array}{c}{ }^{241} \mathrm{Am} \\
\text { (pCi/g dry) }\end{array}$ & $\begin{array}{c}{ }^{137} \mathrm{Cs} \\
\text { (pCi/g dry) }\end{array}$ & $\begin{array}{c}{ }^{238} \mathrm{Pu} \\
\text { (pCi/g dry) }\end{array}$ & $\begin{array}{c}{ }^{239,240} \mathrm{Pu} \\
\text { (pCi/g dry) }\end{array}$ & $\begin{array}{c}{ }^{90} \mathrm{Sr} \\
\text { (pCi/g dry) }\end{array}$ & $\begin{array}{c}{ }^{234} \mathrm{U} \\
\text { (pCi/g dry) }\end{array}$ & $\begin{array}{c}{ }^{235} \mathrm{U} \\
\text { (pCi/g dry) }\end{array}$ & $\begin{array}{c}{ }^{238} \mathrm{U} \\
\text { (pCi/g dry) }\end{array}$ \\
\hline G-58-01 & $\begin{array}{c}0.23 \\
(0.45)\end{array}$ & $\begin{array}{c}0.0030 \\
(0.0056)\end{array}$ & $\begin{array}{l}0.034 \\
(0.15)\end{array}$ & $\begin{array}{l}-0.00080 \\
(0.0059)\end{array}$ & $\begin{array}{c}0.0032 \\
(0.0060)\end{array}$ & $\begin{array}{c}0.13 \\
(0.12)\end{array}$ & $\begin{array}{c}0.91 \\
(0.27)\end{array}$ & $\begin{array}{c}0.042 \\
(0.038)\end{array}$ & $\begin{array}{c}0.88 \\
(0.26)\end{array}$ \\
\hline $\operatorname{Exp} \cdot(8)^{a}$ & $\begin{array}{c}0.34 \\
(0.45)\end{array}$ & $\begin{array}{c}0.0069 \\
(0.0065)\end{array}$ & $\begin{array}{l}0.37 \\
(0.20)\end{array}$ & $\begin{array}{c}0.0033 \\
(0.0060)\end{array}$ & $\begin{array}{c}0.011 \\
(0.010)\end{array}$ & $\begin{array}{l}0.086 \\
(0.13)\end{array}$ & $\begin{array}{l}0.80 \\
(0.24)\end{array}$ & $\begin{array}{c}0.044 \\
(0.038)\end{array}$ & $\begin{array}{c}0.92 \\
(0.27)\end{array}$ \\
\hline RSRL $^{\text {b }}$ & 0.94 & 0.018 & 0.69 & 0.007 & 0.032 & 0.41 & 1.3 & 0.12 & 1.4 \\
\hline$S_{A L}{ }^{c}$ & $6,400^{\mathrm{e}}$ & 39 & 5.3 & 49 & 44 & 5.7 & 63 & 17 & 93 \\
\hline
\end{tabular}

${ }^{\mathrm{a}}$ Expansion Area located just west of Area $\mathrm{G}$ and the data are being gathered for baseline use.

${ }^{b}$ Regional Statistical Reference Level; this is the upper-limit background concentration (mean plus three standard deviations) based on data from 1999 through 2003 (Fresquez 2004).

${ }^{\mathrm{c}}$ Los Alamos National Laboratory Screening Action Level based on RESRAD version 6.21 (ER 2001). 
Unlike the radionuclide data shown in Table 2 for the soils, most radionuclide concentrations, with the exception of ${ }^{3} \mathrm{H}$, in unwashed overstory vegetation were usually not greater than both the TPU and RSRL values. The RSRL mean values plus three standard deviations were calculated from data collected from 1998 to 2003 (Fresquez and Gonzales 2004). Of the eight overstory samples collected in and around the perimeter of Area G, $67 \%$ of the samples contained detectable concentrations of ${ }^{3} \mathrm{H}$ greater than the RSRLs. The ${ }^{3} \mathrm{H}$ concentrations in overstory samples ranged from 2.3 to $83,000 \mathrm{pCi} / \mathrm{mL}$ for the eight samples assayed. As in previous years, ${ }^{3} \mathrm{H}$ concentrations in overstory vegetation collected outside of Area $\mathrm{G}$ and adjacent to the ${ }^{3} \mathrm{H}$ shafts (locations 1 and 2) exhibited the largest concentrations of any of the samples collected (Nyhan et al., 2004, Fresquez et al., 2004). The highest concentration (4.7E05 pCi/g dry), however, was still below the toxicity reference value of 2E06 pCi/g dry (Fresquez et al., 2003b) and concentrations of ${ }^{3} \mathrm{H}$ in the southern region of Area $\mathrm{G}$ have been shown to decrease with distance to within the RSRL at about $90 \mathrm{~m}$ (295 ft) (Fresquez et al., 2003a).

Radionuclide concentrations in unwashed understory vegetation can be found in Table 4. Most radionuclide concentrations, with the exception of ${ }^{3} \mathrm{H}$, in understory vegetation were either nondetectable or within RSRLs. As observed with the overstory vegetation results for ${ }^{3} \mathrm{H}$, the highest amounts in understory vegetation were associated with plants growing in the southwestern perimeter area of Area $\mathrm{G}$ near the ${ }^{3} \mathrm{H}$ shafts (sample locations 1 and 2). Most of the other radionuclides in understory vegetation collected at Area G were not significantly elevated as compared to RSRLs. Some areas, particularly in the northern section (sample location 4) of Area G, contained ${ }^{241} \mathrm{Am}$ and $\mathrm{Pu}$ isotopes in overstory and understory vegetation above RSRLs.

\section{CONCLUSIONS}

The majority of radionuclide contamination problems in soils and plants were due to ${ }^{3} \mathrm{H},{ }^{241} \mathrm{Am}$, and Pu isotopes. All radionuclide values in soils and plants above RSRLs were still very low (pCi range), say for a few ${ }^{3} \mathrm{H}$ values, and were far below the SALs for soils and toxicity reference values for vegetation. Therefore, exposure to radionuclides in Area $G$ soils and vegetation poses little risk to humans and the environment. 
Table 3. Radionuclide Concentrations (TPU, 99\% confidence level) in Unwashed Overstory Vegetation Collected from Area G in 2004. (Bold Values are Equal to or Greater than Both the TPU and RSRL values.)

\begin{tabular}{|c|c|c|c|c|c|c|c|c|c|}
\hline $\begin{array}{l}\text { Sample } \\
\text { Location } \\
\end{array}$ & $\begin{array}{c}{ }^{3} \mathrm{H} \\
(\mathrm{pCi} / \mathrm{mL})\end{array}$ & $\begin{array}{c}{ }^{241} \mathrm{Am} \\
\text { (pCi/g ash) }\end{array}$ & $\begin{array}{c}{ }^{137} \mathrm{Cs} \\
\text { (pCi/g ash) }\end{array}$ & $\begin{array}{c}{ }^{238} \mathrm{Pu} \\
\text { (pCi/g ash) }\end{array}$ & $\begin{array}{c}{ }^{239,240} \mathrm{Pu} \\
\text { (pCi/g ash) }\end{array}$ & $\begin{array}{c}{ }^{90} \mathrm{Sr} \\
\text { (pCi/g ash) }\end{array}$ & $\begin{array}{c}{ }^{234} U \\
\text { (pCi/g ash) }\end{array}$ & $\begin{array}{c}{ }^{235} \mathrm{U} \\
\text { (pCi/g ash) }\end{array}$ & $\begin{array}{c}{ }^{238} \mathrm{U} \\
\text { (pCi/g ash) }\end{array}$ \\
\hline & 522 & 0.0019 & -0.02 & 0.0003 & 0.0064 & 7.2 & 0.060 & 0.0019 & 0.12 \\
\hline \multirow[t]{2}{*}{1} & (119) & (0.0069) & $(0.72)$ & $(0.0053)$ & $(0.0077)$ & (2.6) & $(0.021)$ & $(0.0036)$ & $(0.036)$ \\
\hline & 83,000 & 0.0078 & 0.10 & 0.0019 & 0.0017 & 6.8 & 0.11 & 0.0054 & 0.18 \\
\hline \multirow[t]{2}{*}{2} & $(19,5600)$ & $(0.0096)$ & $(0.77)$ & $(0.0057)$ & (0.0057) & (2.4) & $(0.032)$ & $(0.0050)$ & $(0.050)$ \\
\hline & 2.3 & 0.020 & -0.09 & 0.0045 & 0.019 & 4.5 & 0.16 & 0.011 & 0.19 \\
\hline \multirow[t]{2}{*}{3} & $(0.81)$ & $(0.017)$ & (0.69) & $(0.0065)$ & $(0.013)$ & (1.7) & $(0.045)$ & $(0.0078)$ & $(0.053)$ \\
\hline & 2.4 & 0.0032 & 0.11 & -0.0006 & 0.0052 & 7.1 & 0.12 & 0.0069 & 0.14 \\
\hline \multirow[t]{2}{*}{$3 \mathbf{b}$} & $(0.84)$ & $(0.0071)$ & (0.35) & $(0.0045)$ & $(0.0060)$ & (2.6) & $(0.036)$ & $(0.0065)$ & $(0.041)$ \\
\hline & 4.1 & 0.38 & 0.10 & 0.023 & 0.30 & 17 & 0.12 & 0.0069 & 0.14 \\
\hline 4 & (1.2) & $(0.12)$ & $(0.83)$ & $(0.015)$ & $(0.087)$ & (5.9) & $(0.035)$ & $(0.0057)$ & (0.039) \\
\hline \multirow[t]{3}{*}{$6 \mathbf{b}$} & 2.0 & 0.051 & 0.03 & 0.0001 & 0.054 & 9.4 & 0.082 & 0.0025 & 0.14 \\
\hline & $(0.77)$ & $(0.027)$ & (0.57) & $(0.0045)$ & $(0.023)$ & (3.3) & $(0.027)$ & $(0.0057)$ & $(0.041)$ \\
\hline & 7.6 & 0.0043 & 0.24 & & & 0.17 & 0.12 & 0.0079 & 0.11 \\
\hline \multirow[t]{2}{*}{$7 a$} & (2.0) & $(0.0038)$ & (0.89) & $\mathrm{a}$ & $\mathrm{a}$ & $(0.071)$ & $(0.032)$ & $(0.0050)$ & $(0.030)$ \\
\hline & 6.1 & 0.046 & -0.14 & 0.013 & 0.054 & 6.4 & 0.15 & 0.011 & 0.17 \\
\hline 7c & (1.7) & $(0.026)$ & $(0.80)$ & $(0.011)$ & $(0.024)$ & (2.3) & $(0.044)$ & (0.0078) & $(0.048)$ \\
\hline $\begin{array}{l}\text { Expansion } \\
\text { area }(8)\end{array}$ & $\begin{array}{l}2.0 \\
(0.78)\end{array}$ & $\begin{array}{c}0.0033 \\
(0.0063)\end{array}$ & $\begin{array}{l}-0.14 \\
(0.81)\end{array}$ & $\begin{array}{c}0.0002 \\
(0.0050)\end{array}$ & $\begin{array}{c}0.0039 \\
(0.0063)\end{array}$ & $\begin{array}{c}3.5 \\
(1.3)\end{array}$ & $\begin{array}{c}0.097 \\
(0.030)\end{array}$ & $\begin{array}{c}0.0044 \\
(0.0050)\end{array}$ & $\begin{array}{c}0.12 \\
(0.036)\end{array}$ \\
\hline RSRL $^{\text {b }}$ & 2.3 & 0.052 & 0.62 & 0.070 & 0.052 & 13 & 0.50 & 0.021 & 0.44 \\
\hline
\end{tabular}

${ }^{\mathrm{a}}$ Lost in analysis.

${ }^{\mathrm{b}}$ Regional Statistical Reference Level; this is the upper-limit background concentration (mean plus three standard deviations) based on data from 1998 through 2003 (Fresquez and Gonzales 2004). 
Table 4. Radionuclide Concentrations (TPU, 99\% confidence level) in Unwashed Understory Vegetation Collected from Area $G$ in 2004. (Bold Values are Equal to or Greater than Both the TPU and RSRL values.)

\begin{tabular}{|c|c|c|c|c|c|c|c|c|c|}
\hline $\begin{array}{c}\text { Sample } \\
\text { Location }\end{array}$ & $\begin{array}{c}{ }^{3} \mathrm{H} \\
(\mathrm{pCi} / \mathrm{mL})\end{array}$ & $\begin{array}{c}{ }^{241} \mathrm{Am} \\
\text { (pCi/g ash) }\end{array}$ & $\begin{array}{c}{ }^{137} \mathrm{Cs} \\
\text { (pCi/g ash) }\end{array}$ & $\begin{array}{c}{ }^{238} \mathrm{Pu} \\
\text { (pCi/g ash) }\end{array}$ & $\begin{array}{c}{ }^{239,240} \mathrm{Pu} \\
\text { (pCi/g ash) }\end{array}$ & $\begin{array}{c}{ }^{90} \mathrm{Sr} \\
\text { (pCi/g ash) }\end{array}$ & $\begin{array}{c}{ }^{234} \mathrm{U} \\
\text { (pCi/g ash) }\end{array}$ & $\begin{array}{c}{ }^{235} \mathrm{U} \\
\text { (pCi/g ash) }\end{array}$ & $\begin{array}{c}{ }^{238} \mathrm{U} \\
\text { (pCi/g ash) }\end{array}$ \\
\hline & 465 & 0.0 & 0.16 & 0.0007 & 0.0032 & 1.1 & 0.028 & 0.0033 & 0.025 \\
\hline \multirow[t]{2}{*}{1} & (107) & $(0.0071)$ & $(0.86)$ & (0.0069) & (0.0069) & $(0.41)$ & $(0.012)$ & $(0.0039)$ & $(0.011)$ \\
\hline & 390 & 0.0037 & -0.32 & 0.0 & 0.0022 & 1.1 & 0.026 & 0.0010 & 0.028 \\
\hline \multirow[t]{2}{*}{2} & (89) & $(0.0070)$ & $(0.81)$ & $(0.0063)$ & $(0.0063)$ & $(0.38)$ & $(0.012)$ & (0.0039) & (0.013) \\
\hline & 2.9 & 0.0026 & -0.07 & 0.0 & 0.0052 & 1.5 & 0.070 & 0.0016 & 0.083 \\
\hline \multirow[t]{2}{*}{3} & $(0.81)$ & $(0.0074)$ & $(0.80)$ & $(0.0074)$ & $(0.0080)$ & $(0.54)$ & $(0.024)$ & $(0.0039)$ & $(0.027)$ \\
\hline & 2.0 & 0.0017 & -0.11 & -0.0014 & 0.0 & 1.7 & 0.041 & 0.0041 & 0.041 \\
\hline \multirow[t]{2}{*}{$3 \mathbf{b}$} & $(0.74)$ & $(0.0062)$ & $(0.80)$ & $(0.0063)$ & $(0.0063)$ & (0.59) & $(0.017)$ & $(0.0044)$ & $(0.017)$ \\
\hline & 2.5 & 0.034 & 0.25 & 0.017 & 0.013 & 1.6 & 0.046 & 0.0005 & 0.038 \\
\hline \multirow[t]{2}{*}{4} & $(0.75)$ & $(0.021)$ & $(0.79)$ & $(0.014)$ & $(0.012)$ & (0.59) & $(0.020)$ & $(0.0051)$ & $(0.015)$ \\
\hline & 1.4 & 0.0012 & -0.24 & -0.0003 & 0.0022 & 1.5 & 0.023 & 0.0010 & 0.021 \\
\hline \multirow[t]{2}{*}{$6 b$} & $(0.57)$ & $(0.0066)$ & $(0.77)$ & $(0.0063)$ & $(0.0063)$ & $(0.53)$ & $(0.011)$ & $(0.0039)$ & $(0.011)$ \\
\hline & 13 & 0.0044 & 4.1 & 0.0034 & 0.0020 & 5.3 & 0.090 & 0.0019 & 0.074 \\
\hline $7 a$ & (3.0) & $(0.0068)$ & (1.2) & $(0.0065)$ & $(0.0065)$ & (1.8) & $(0.029)$ & $(0.0036)$ & $(0.024)$ \\
\hline \multirow[t]{3}{*}{$7 \mathbf{b}$} & 13 & 0.0007 & 0.01 & 0.0023 & -0.0018 & 0.48 & 0.052 & 0.0028 & 0.052 \\
\hline & (3.0) & $(0.0068)$ & $(0.81)$ & $(0.0060)$ & $(0.0060)$ & (0.18) & $(0.018)$ & $(0.0045)$ & $(0.018)$ \\
\hline & 2.7 & 0.0060 & 0.49 & 0.0042 & 0.014 & 1.6 & 0.061 & 0.0015 & 0.065 \\
\hline 7c & $(0.90)$ & $(0.0083)$ & $(0.78)$ & $(0.0072)$ & $(0.013)$ & $(0.57)$ & $(0.021)$ & $(0.0038)$ & $(0.023)$ \\
\hline $\begin{array}{l}\text { Expansion area } \\
\text { (8) }\end{array}$ & $\begin{array}{l}1.9 \\
(0.77)\end{array}$ & $\begin{array}{c}0.0062 \\
(0.0084)\end{array}$ & $\begin{array}{l}-0.19 \\
(0.78)\end{array}$ & $\begin{array}{c}0.0006 \\
(0.0062)\end{array}$ & $\begin{array}{l}-0.0005 \\
(0.0062)\end{array}$ & $\begin{array}{c}0.69 \\
(0.26)\end{array}$ & $\begin{array}{c}0.027 \\
(0.012)\end{array}$ & $\begin{array}{c}0.0038 \\
(0.0050)\end{array}$ & $\begin{array}{c}0.030 \\
(0.013)\end{array}$ \\
\hline RSRL $^{a}$ & 3.6 & 0.0093 & 0.63 & 0.0049 & 0.015 & 5.0 & 1.3 & 0.052 & 1.1 \\
\hline
\end{tabular}




\section{ACKNOWLEDGMENTS}

Thanks to the 2004 field crew (Louis Naranjo, Jr., Brian Spall, and Gaylene Fred) for sample collection and processing. Also, special thanks to Hector Hinojosa for editing and to Teresa Hiteman for composition work.

\section{REFERENCES}

ASTM (American Society for Testing and Materials), "Standard Practice for Sampling Surface Soil for Radionuclides," in Annual Book of ASTM Standards, American Society for Testing and Materials, Philadelphia, PA (1990).

Childs, M. and R. Conrad, "Area G Perimeter Surface-Soil and Single-Stage Water Sampling, Environmental Surveillance for Fiscal Year 95," Los Alamos National Laboratory report LA-13369-PR (1997).

Conrad, R., M. Childs, C. Rivera-Dirks, and F. Coriz, "Area G Perimeter Surface-Soil and Single-Stage Water Sampling: Environmental Surveillance for Fiscal Year 1993," Los Alamos National Laboratory report LA-12986 (1995).

ER (Environmental Restoration), "Derivation and Use of Radionuclide Screening Action Levels," Los Alamos National Laboratory report LA-UR-01-990 (2001).

Fresquez, P.R., "Soil Monitoring," pp. 185-200 in "Environmental Surveillance at Los Alamos during 2003," Los Alamos National Laboratory report LA-14162-ENV (2004).

Fresquez, P.R., M.A. Mullen, J.K. Ferenbaugh, and R.A. Perona, "Radionuclides and Radioactivity in Soils Within and Around Los Alamos National Laboratory, 1974 to 1994: Concentrations, Trends, and Dose Comparisons," Los Alamos National Laboratory report LA-13149-MS (1996).

Fresquez, P.R., E.L. Vold, and L. Naranjo, Jr., "Radionuclide Concentrations in Soils and Vegetation at Radioactive-Waste Disposal Area G during the 1996 Growing Season," Los Alamos National Laboratory report LA-13332-PR (1997).

Fresquez, P.R., L.M. Vasquez-Tator, and E.A. Lopez, "Tritium Concentrations in Vegetation as a Function of Distance from a Low-Level Radioactive Waste Site at Los Alamos National Laboratory," Los Alamos National Laboratory report LA-14091-MS (2003a).

Fresquez, P.R., J. Nyhan, B. Gallaher, and G. Gonzales, "Soil Monitoring," Chapter 7 in "Environmental Surveillance at Los Alamos during 2002," Los Alamos National Laboratory report LA-14085-ENV (2003b).

Fresquez, P.R. and G.J. Gonzales, "Radionuclide Concentrations in Vegetation at the Los Alamos National Laboratory in 2002/2003," Los Alamos National Laboratory report LA14160-PR (2004).

Hakonson, T.E., R.L. Watters, and W.C. Hanson, "The Transport of Plutonium in Terrestrial Ecosystems," Health Physics 40:63-69 (1981). 
Hansen, W.R., D.L. Mayfield, and L.J. Walker, "Interim Environmental Surveillance Plan for LASL Radioactive Waste Areas,” Los Alamos Scientific Laboratory report LAUR-80-3110 (1980).

Healy, J.W., “An Examination of the Pathways from Soil to Man for Plutonium,” Los Alamos Scientific Laboratory report LA-6741-MS (1977).

Lopez, E.A., “MDA G and L Environmental Monitoring Plan for FY 2002,” Los Alamos National Laboratory report LA-UR-02-6128 (2002).

Nyhan, J.W., P.R. Fresquez, W.R. Velasquez, and E.A. Lopez, "Radionuclide Concentrations in Soils and Vegetation at Low-Level Radioactive Waste Disposal Area G during the 2001 Growing Season,” Los Alamos National Laboratory report LA-13942PR (2002).

Nyhan, J.W., P.R. Fresquez, K.D. Bennett, and E.A. Lopez, "Radionuclide Concentrations in Soils and Vegetation at Low-Level Radioactive Waste Disposal Area G during the 2002 Growing Season (with a summary of radionuclide concentrations in soils and vegetation since 1980)," Los Alamos National Laboratory report LA-14095-PR (2004).

Purtymun, W.D., M.A. Rogers, and M.L. Wheeler, "Radiochemical Analyses of Samples from Beneath a Solid Radioactive Waste Disposal Pit at Los Alamos, New Mexico,” Los Alamos Scientific Laboratory report LA-8422-MS (1980).

Rickard, W.H. and L.J. Kirby, "Trees as Indicators of Subterranean Water Flow from a Retired Radioactive Waste Disposal Site,” Health Physics 52(2):201-206 (1987).

Salazar, J.G., "Produce and Fish Sampling Program of Los Alamos National Laboratory’s Environmental Surveillance Group,” Los Alamos National Laboratory report LA-10186-MS (1984).

Soholt, L.F., "Environmental Surveillance of Low-Level Radioactive-WasteManagement Areas at Los Alamos During 1987,” Los Alamos National Laboratory report LA-UR-90-3283 (1990).

Tierney, G.D. and T.S. Foxx, "Floristic Composition and Plant Succession on NearSurface Radioactive Waste Disposal Facilities in the Los Alamos National Laboratory," Los Alamos National Laboratory report LA-9219-MS (1982).

U.S. DOE, "Final Environmental Impact Statement: Los Alamos Scientific Laboratory Site, Los Alamos, New Mexico,” U.S. Department of Energy report DOE/EIS-0018 (1979).

Wenzel, W.J., T.S. Foxx, A.F. Gallegos, G. Tierney, and J.C. Rodgers, “Cesium-137, Plutonium-239/240, Total Uranium, and Scandium in Trees and Shrubs Growing in Transuranic Waste at Area B,” Los Alamos National Laboratory report LA-11126-MS (1987). 
APPENDIX A

ANALYTICAL DATA REPORTS OF RADIONUCLIDE CONCENTRATIONS IN SOILS COLLECTED AT AREA G DURING 2004 


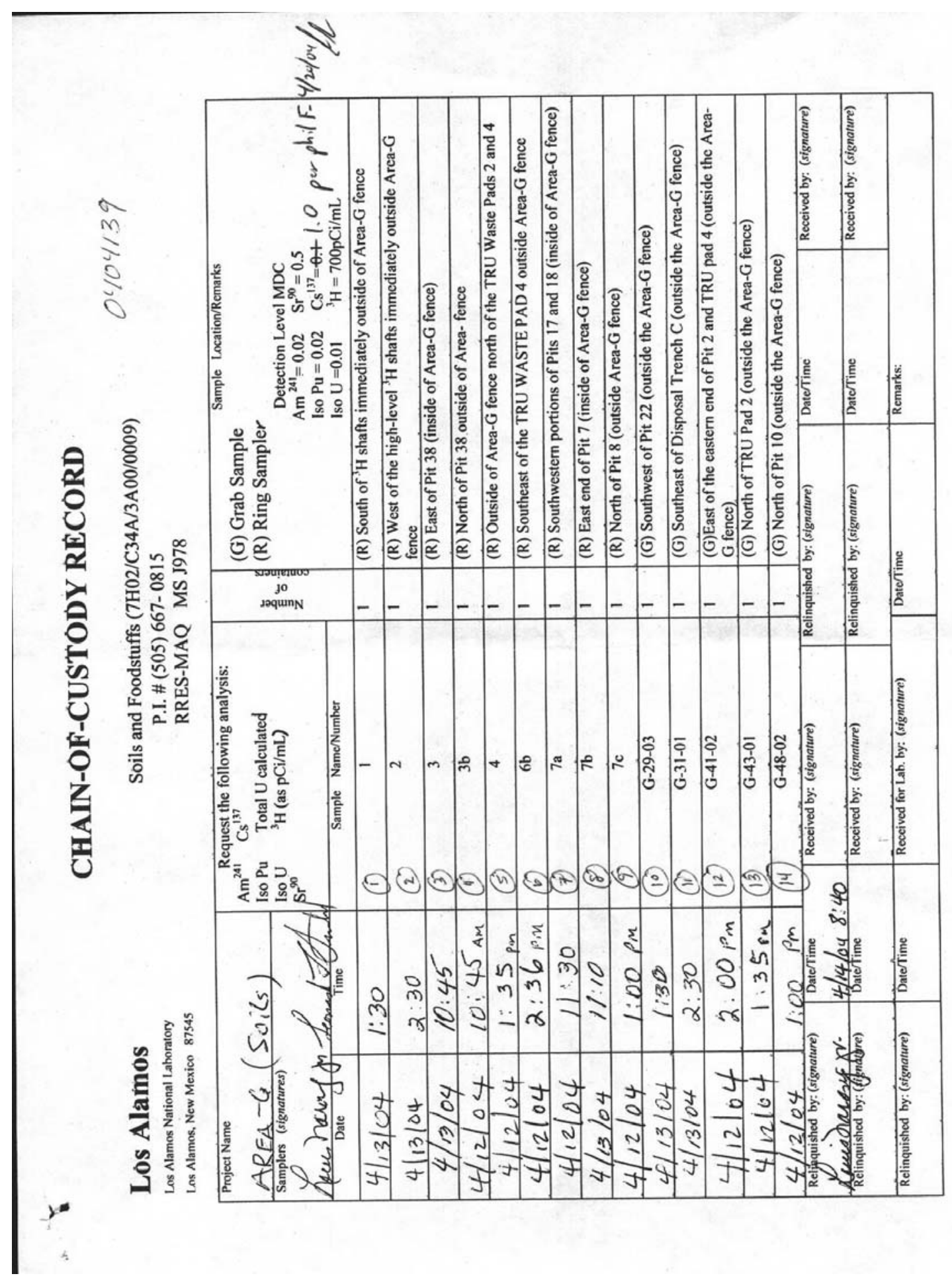




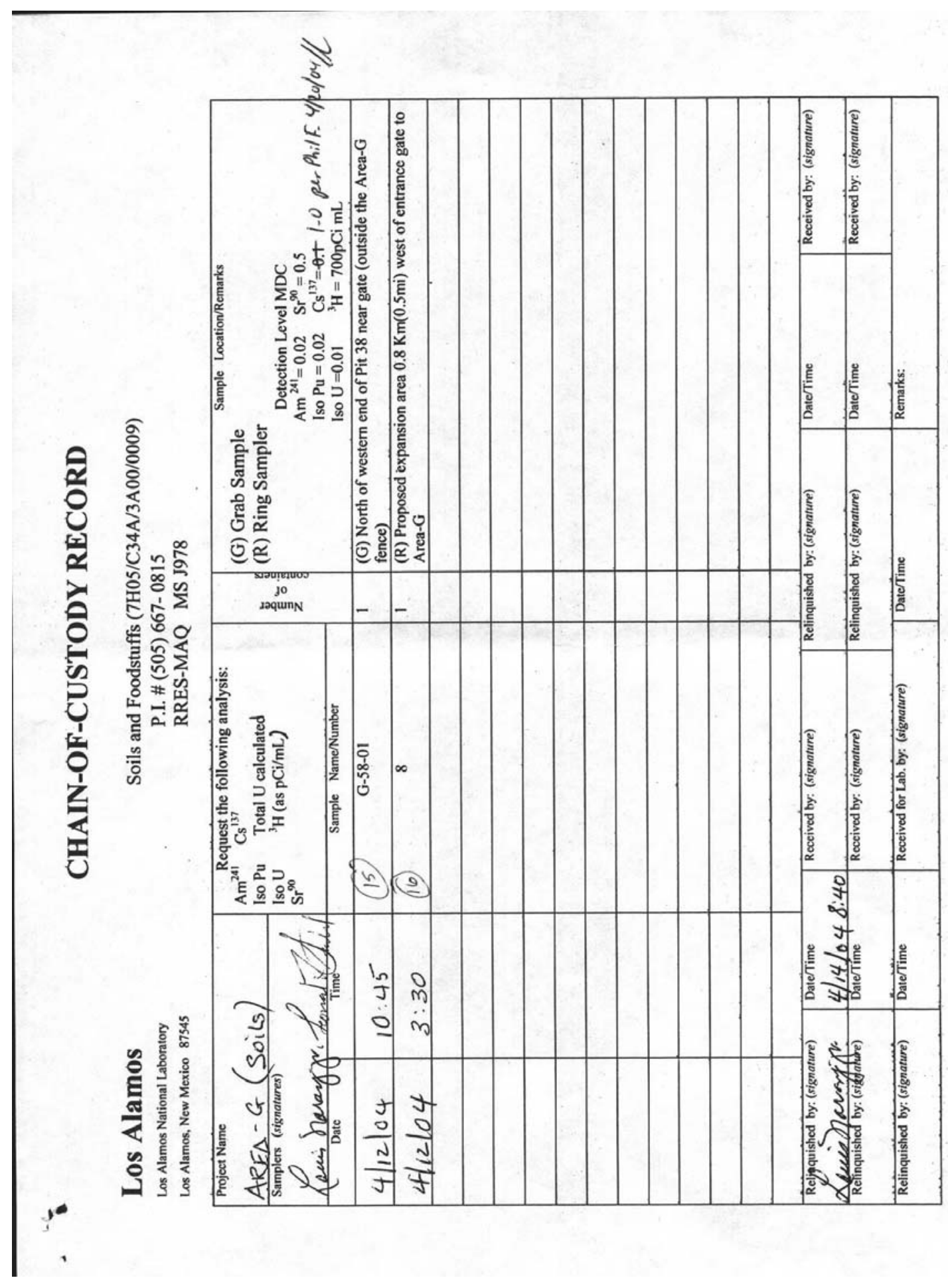



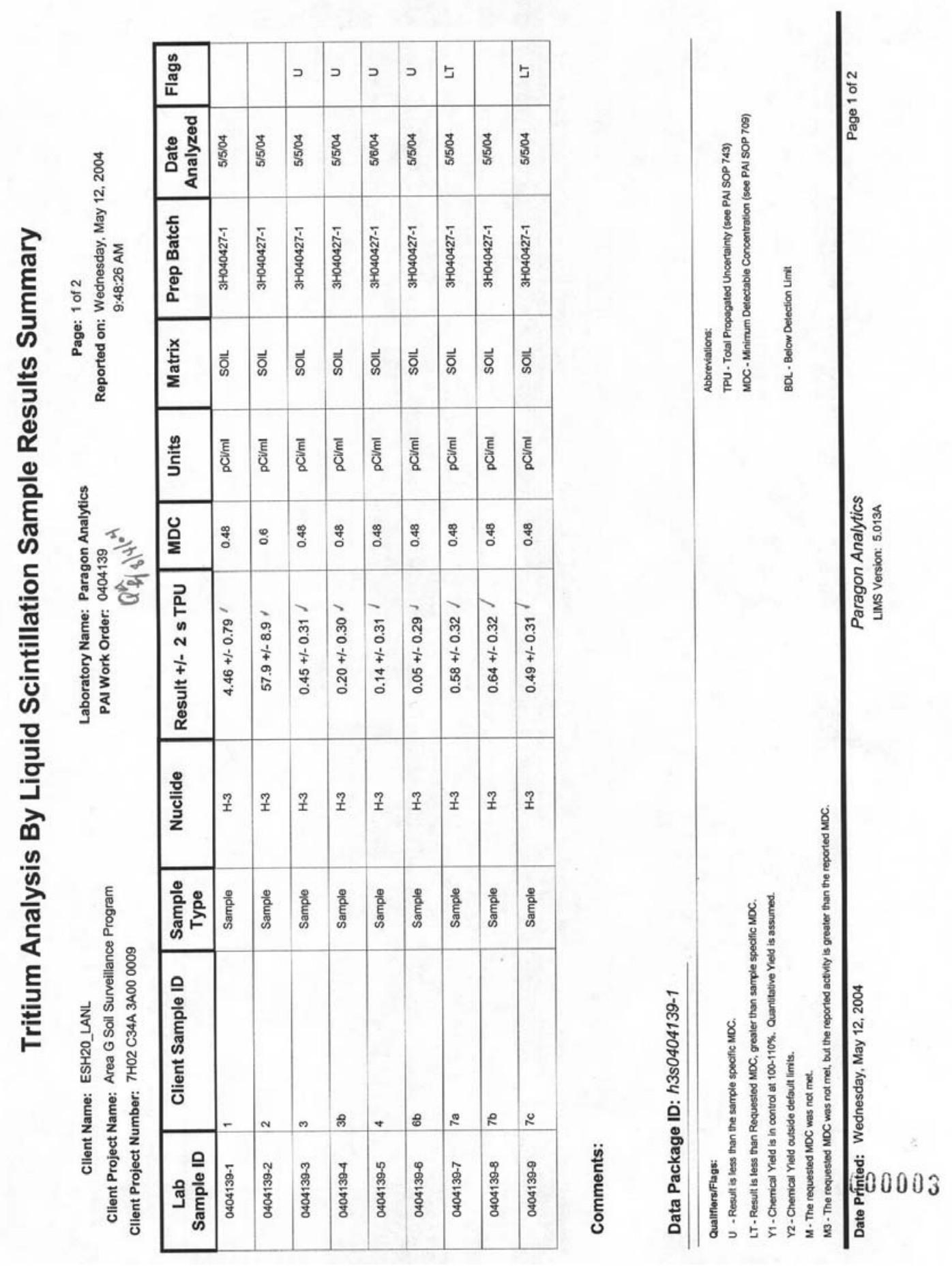

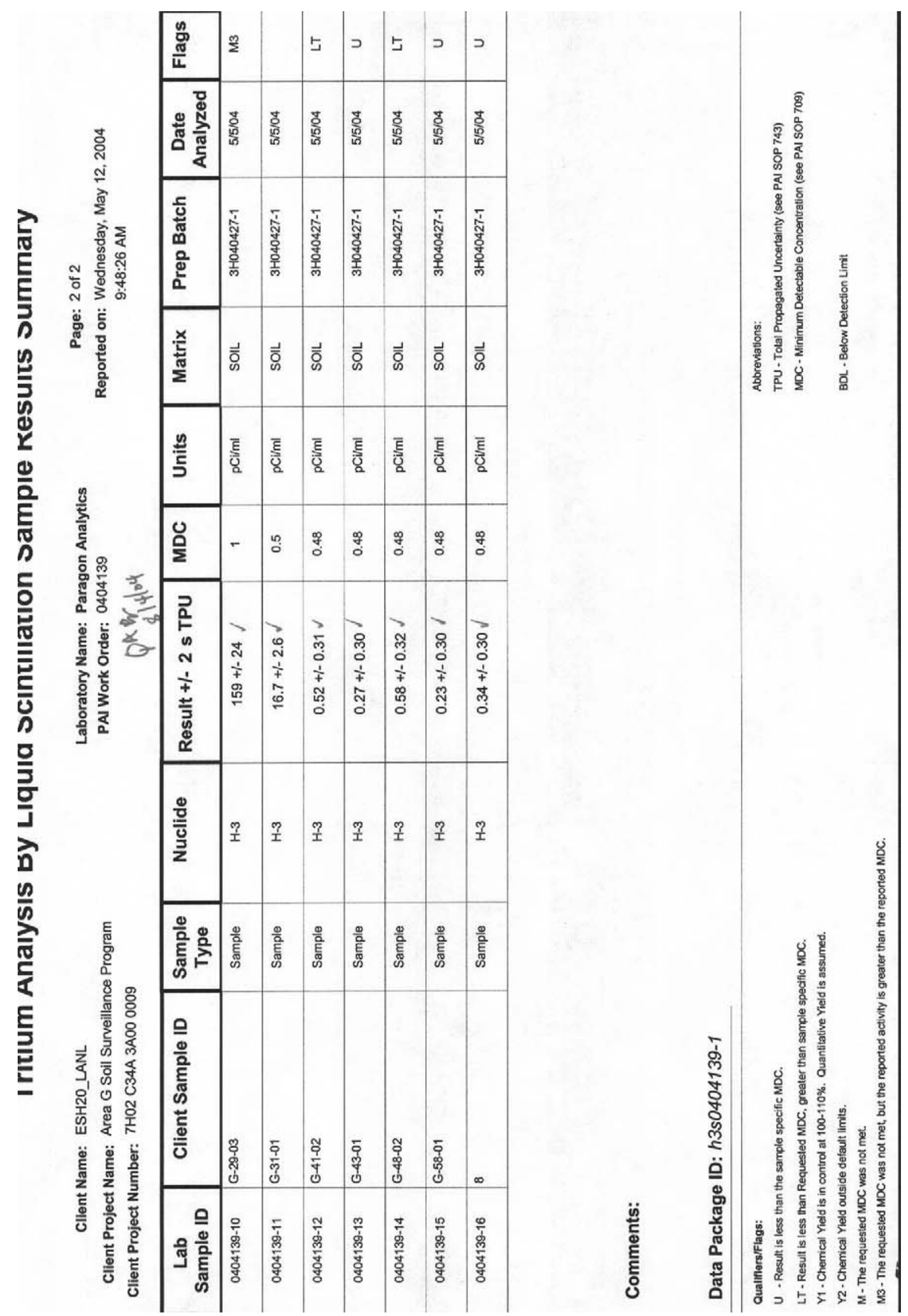

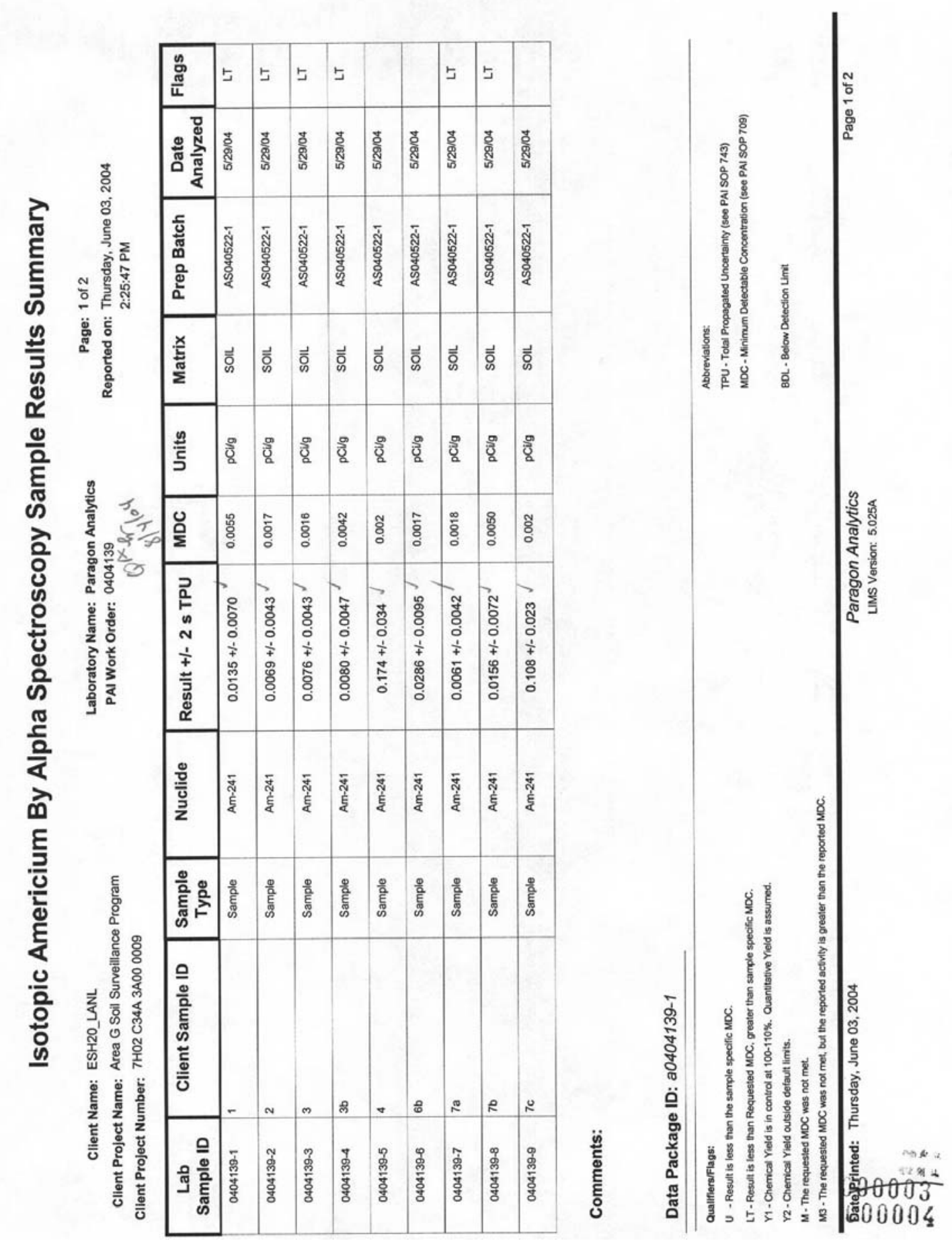

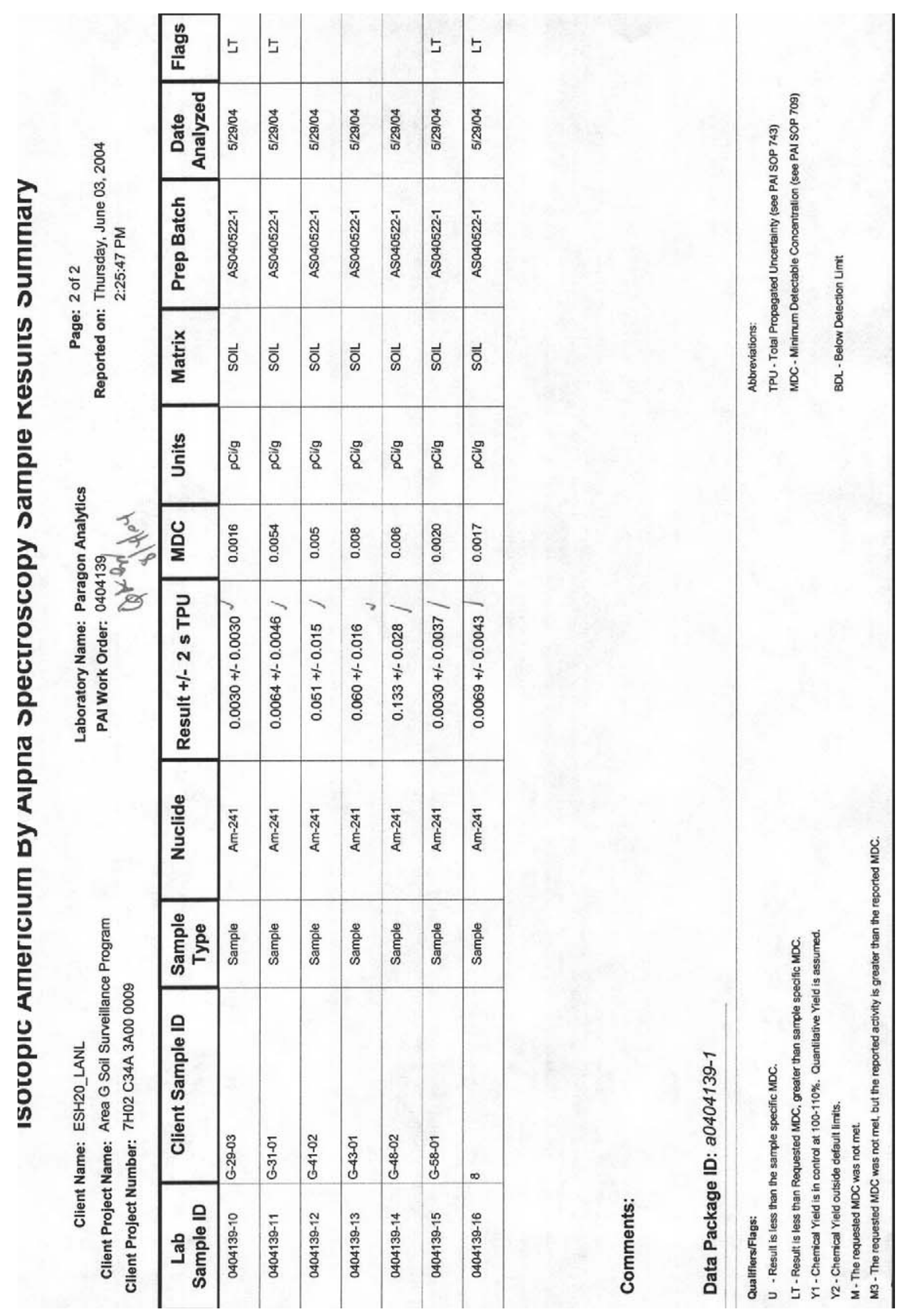


\section{Gamma Spectroscopy Results}

PAI 713 Rev 8

Sample Results

Lab Name: Paragon Analytics

Work Order Number: 0404139

Client Name: ESH2O_LANL

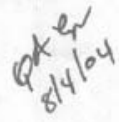

ClientProject ID: Area G Soil Surveillance Program 7H02 C34A 3 A00 0009

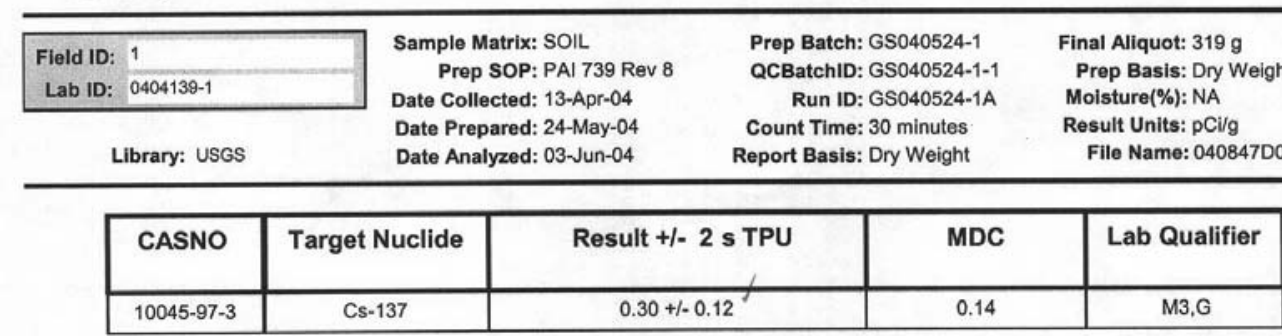

Comments:

\begin{tabular}{|c|c|}
\hline \multicolumn{2}{|l|}{ Qualiflers/Flags: } \\
\hline$U$ - Result is less than the sample specific MDC or less than the associaled TPU & SQ - Spectral quallity prevents accurate quantitation. \\
\hline $\mathrm{Y1}$ - Chemical Vield is in control at 100-110\%. Quantitative Yield is assumed. & SI- Nuclide identification and/or quantitation is tentative. \\
\hline Y2 - Chemical Vield outsice default limits. & $\mathrm{TI}$ - Nuclide identification is tentative. \\
\hline LT - Result is less than Requested MDC, greater than sample specific MDC. & $R \cdot$ - Nuclide has exceeded 8 halfives. \\
\hline $\begin{array}{l}\text { M3 - The requested MDC was not met, but the reported } \\
\text { activity is greater than the reported MDC. }\end{array}$ & G. Sample densily differs by more than $15 \%$ of LCS density. \\
\hline \multicolumn{2}{|l|}{ M - The requested MDC was nor met. } \\
\hline \multicolumn{2}{|l|}{ Abtreviations: } \\
\hline \multicolumn{2}{|l|}{ TPU - Total Propagated Uncertainty (see PAI SOP 743) } \\
\hline \multicolumn{2}{|l|}{ MDC - Minimum Detectable Concentration (see PAI SOP 709) } \\
\hline \multicolumn{2}{|l|}{ 8OL - Below Detection Limit } \\
\hline \multicolumn{2}{|l|}{ Data Package ID: GSS0404139-1 } \\
\hline
\end{tabular}




\title{
Gamma Spectroscopy Results
}

\section{PAI 713 Rev 8}

Lab Name: Paragon Analytics

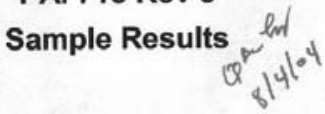

Work Order Number: 0404139

Client Name: ESH2O_LANL

ClientProject ID: Area G Soil Surveillance Program 7H02 C34A 3A00 0009

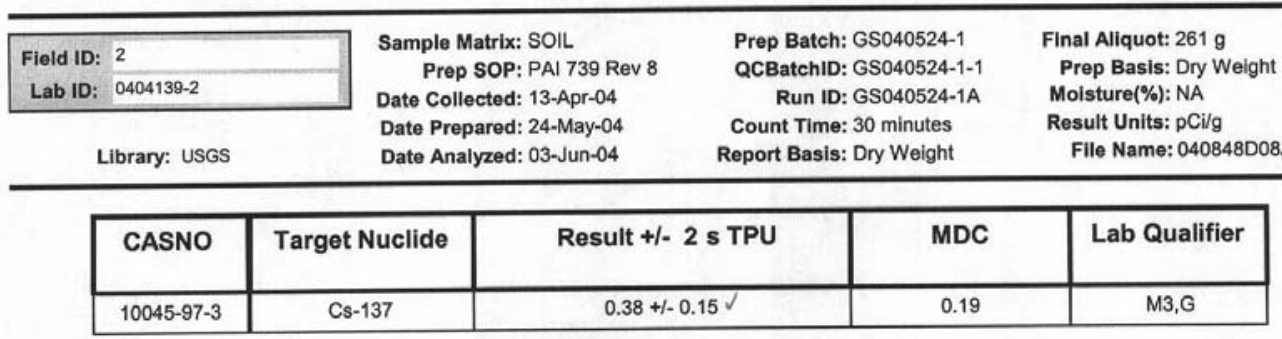

Comments:

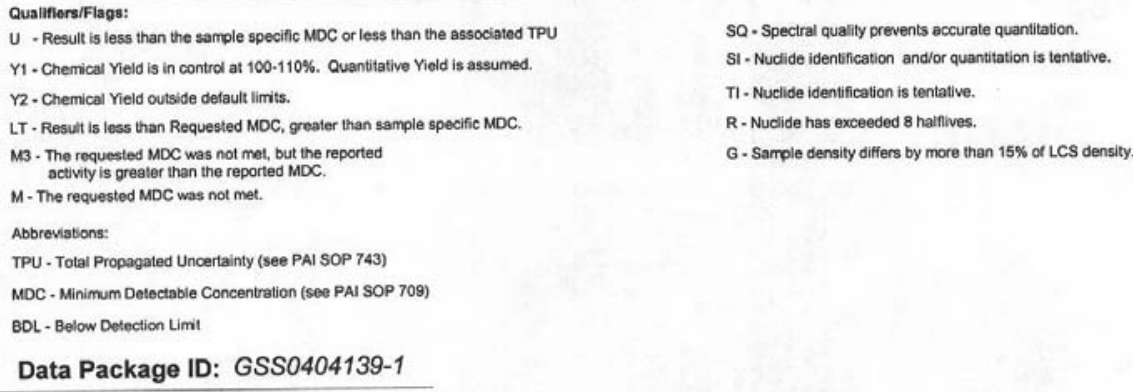

Date Printed: Thursday, June 10, 2004 


\section{Gamma Spectroscopy Results}

PAl 713 Rev 8

Lab Name: Paragon Analytics

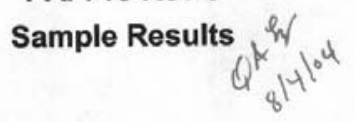

Work Order Number: 0404139

Client Name: ESH20_LANL

ClientProject ID: Area G Soil Surveillance Program 7H02 C34A 3A00 0009

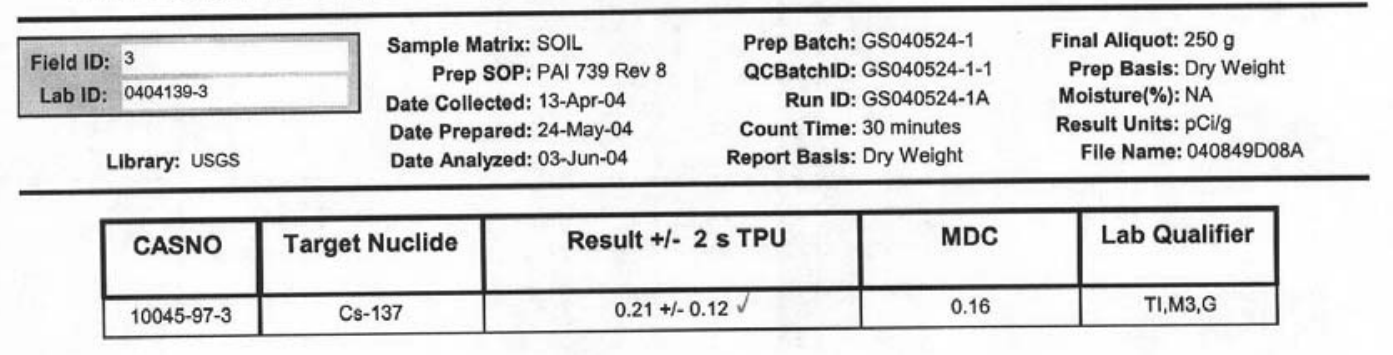

Comments:

\begin{tabular}{|c|c|}
\hline \multicolumn{2}{|r|}{ SO-SOectral quality prevents accurate quantitation. } \\
\hline U - Result is less than the sample specific MDC or less than the associated TPU & SQ - Spectral quality prevents accurate quantitation. \\
\hline Y1 - Chemical Yeld is in control at 100-110\%. Quantitatlive Yield is assumed. & S1 - Nudide Identification and/or quantitation is tentative. \\
\hline Y2. Cherrical Yield outside default limits. & $\mathrm{TI}$ - Nuclide identfication is tentative. \\
\hline LT - Result is less than Requested MDC, greater than sample specific MDC. & R. Nuclide has exceeded 8 hainives. \\
\hline $\begin{array}{l}\text { Ma - The requested MDC was nol met, but the reported } \\
\text { activily is greater than the reported MDC. }\end{array}$ & G. Sample density differs by more than $15 \%$ of LCS density. \\
\hline \multicolumn{2}{|l|}{ M. The requested MOC was nol met. } \\
\hline \multicolumn{2}{|l|}{ Abbreviations: } \\
\hline \multicolumn{2}{|l|}{ TPU - Total Propagated Uncortainty (see PAI SOP 743) } \\
\hline \multicolumn{2}{|l|}{ MDC - Minimum Detectable Concentration (see PAI SOP 709) } \\
\hline \multicolumn{2}{|l|}{ BDL. Below Detection Umit } \\
\hline Data Package ID: GSS0404139-1 & \\
\hline
\end{tabular}

Date Printed: Thursday, June 10, 2004 


\section{Gamma Spectroscopy Results}

PAI 713 Rev 8

Sample Results

Lab Name: Paragon Analytics

Work Order Number: 0404139

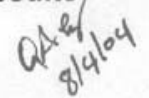

Client Name: ESH2O_LANL

ClientProject ID: Area G Soil Surveillance Program 7H02 C34A 3A00 0009

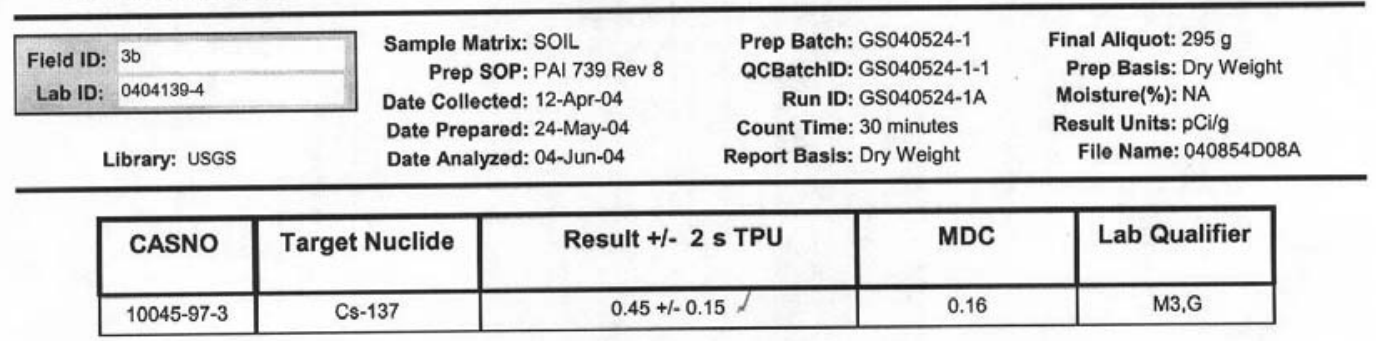

Comments:

\begin{tabular}{|c|c|}
\hline \multicolumn{2}{|l|}{ Quallifiers/Flags: } \\
\hline$U$ - Result is less than the sample specific MDC or less than the associated TPU & SQ - Spectral quality prevents accurate quantitation. \\
\hline Y1 - Chemical Yield is in control at 100-110\%. Quantitative Yield is assumod. & SI- Nuclide identification and/or quantitation is tentative. \\
\hline Y2. Cherrical Yield outside default limits. & $\mathrm{T}$ - Nudide identification is tentative. \\
\hline LT - Result is less than Requested MDC, greater than sample specific MDC. & R - Nuclide has exceeded 8 halfivives. \\
\hline $\begin{array}{l}\text { M3 - The requested MDC was not met, but the reported } \\
\text { activity is greater than the reported MDC. }\end{array}$ & G - Sample density differs by more than $15 \%$ of LCS density. \\
\hline \multicolumn{2}{|l|}{ M - The requested MOC was not met. } \\
\hline \multicolumn{2}{|l|}{ Abbreviations: } \\
\hline \multicolumn{2}{|l|}{ TPU - Total Propagated Uncertainty (see PAI SOP 743) } \\
\hline \multicolumn{2}{|l|}{ MOC - Mnimum Detectable Concentration (see PAI SOP 709) } \\
\hline \multicolumn{2}{|l|}{ BDL-Below Detection Limit } \\
\hline Data Package ID: GSS0404139-1 & \\
\hline
\end{tabular}

Date Printed: Thursday, June 10, 2004 


\section{Gamma Spectroscopy Results}

PAI 713 Rev 8

Lab Name: Paragon Analytics

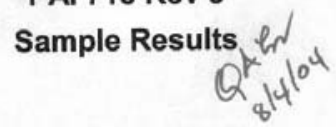

Work Order Number: 0404139

Client Name: ESH20_LANL

ClientProject ID: Area G Soil Surveillance Program 7H02 C34A 3A00 0009

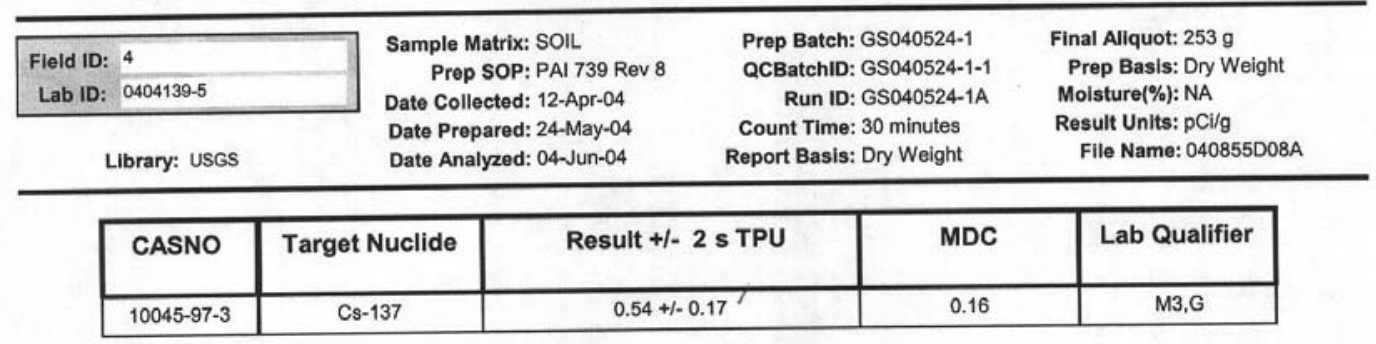

Comments:

\begin{tabular}{|c|c|}
\hline \multicolumn{2}{|l|}{ Qualifiers/Flags: } \\
\hline U - Result is less than the sample specific MDC or less than the associated TPU & SQ - Spectral quality prevents accurate quantitation. \\
\hline Y1 - Chemical Yield is in control at 100-110\%. Quantitative Yield is assumed. & S1 - Nuclide identification and/or quantiation is temtative. \\
\hline Yz-Cherrical Yield outside default limits. & $\mathrm{Tl}$ - Nuclide identfication is tentative. \\
\hline LT - Result is less than Requested MDC, greater than sample specific MDC. & R - Nuclide has exceeded 8 haiflives. \\
\hline $\begin{array}{l}\text { M3 - The requested MDC was not met, but the reported } \\
\text { activity is greater than the reported MDC. }\end{array}$ & G. Sample density differs by more than $15 \%$ of LCS density. \\
\hline \multicolumn{2}{|l|}{$M$ - The requested MDC was not met. } \\
\hline \multicolumn{2}{|l|}{ Abbreviations: } \\
\hline \multicolumn{2}{|l|}{ TPU - Total Propagated Uncertainty (see PAI SOP 743) } \\
\hline \multicolumn{2}{|l|}{ MDC - Minimum Detectable Concentration (see PAI SOP 709) } \\
\hline \multicolumn{2}{|l|}{ BDL - Below Detection Limit } \\
\hline Data Package ID: GSS0404139-1 & \\
\hline
\end{tabular}

Date Printed: Thursday, June 10, 2004 


\section{Gamma Spectroscopy Results}

\section{PAI 713 Rev 8}

Lab Name: Paragon Analytics

Sample Results

Work Order Number: 0404139

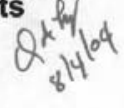

Client Name: ESH2O_LANL

ClientProject ID: Area G Soil Surveillance Program 7H02 C34A 3A00 0009

\begin{tabular}{|c|c|c|c|}
\hline Field ID: $6 \mathrm{~b}$ & Sample Matrix: SOIL & Prep Batch: GS040524-1 & Final Aliquot: $346 \mathrm{~g}$ \\
\hline Lab ID: $0404139-6$ & $\begin{array}{l}\text { Prep SOP: PAI } 739 \text { Rev } 8 \\
\text { Collected: } 12 \text {-Apr-04 }\end{array}$ & QCBatchID: GS040524-1-1 & Prep Basis: Dry Weight \\
\hline & Date Prepared: 24-May-04 & Count Time: 30 minutes & Result Units: $\mathrm{pCl} / \mathrm{g}$ \\
\hline Library: USGS & Date Analyzed: 04-Jun-04 & Report Basis: Dry Weight & File Name: $040856 \mathrm{D} 08 \mathrm{~A}$ \\
\hline
\end{tabular}

\begin{tabular}{|c|c|c|c|c|}
\hline CASNO & Target Nuclide & Result +/- 2 s TPU & MDC & Lab Qualifier \\
\hline $10045-97-3$ & Cs-137 & $0.28+1-0.12$ & 0.16 & M3,G \\
\hline
\end{tabular}

Comments:

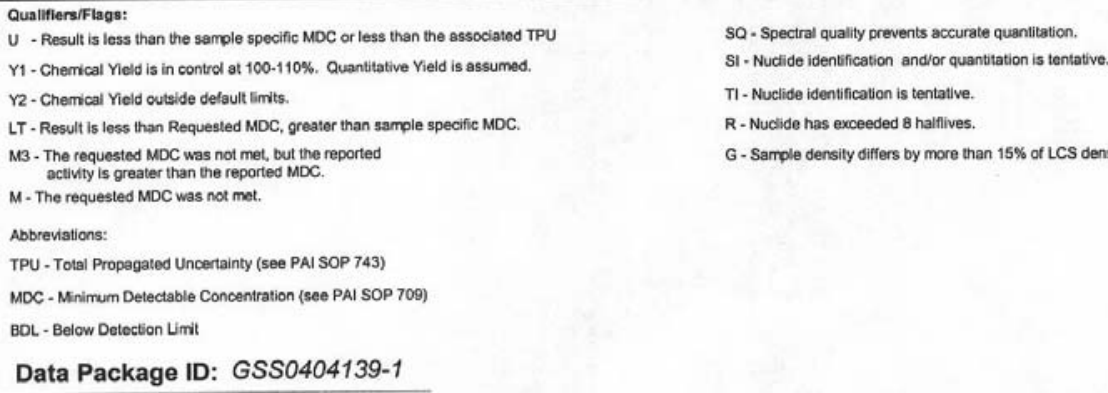

$U$ - Result is less than the sample specific MDC or less than the associated TPU

SQ - Spectral quality prevents accurate quantitation.

$U$-Result is less than the sample specific MDC or less than the associated TPU
$\mathrm{Y} 1$ - Chemical Yleid is in control at $100-110 \%$. Quantitative Vield is assumed.

$\mathrm{SI}$ - Nuclide idenlficication and/or quantitation is tentative.

Y2-Chemical Yield outside default limits.

LT - Result is less than Requested MDC, greater than sample specific MDC.

M3 - The requested MDC was not met, but the reported

TI- Nuclide identification is tentative.

$R$ - Nuclide has exceeded 8 halfilives.

activity is greater than the report.
- The requested MDC was not met.

Abbreviations:

TPU - Total Propagated Uncertainty (see PAI SOP 743)

MDC - Minimum Detectable Concentration (see PAI SOP 709)

BOL-Below Detoction Limit

Data Package ID: GSS0404139-1

Date Printed: Thursday, June 10, 2004 


\section{Gamma Spectroscopy Results}

\section{PAI 713 Rev 8}

Sample Results $h$

Lab Name: Paragon Analytics

Work Order Number: 0404139

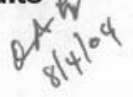

Client Name: ESH20_LANL

ClientProject ID: Area G Soil Surveillance Program 7H02 C34A 3 A00 0009

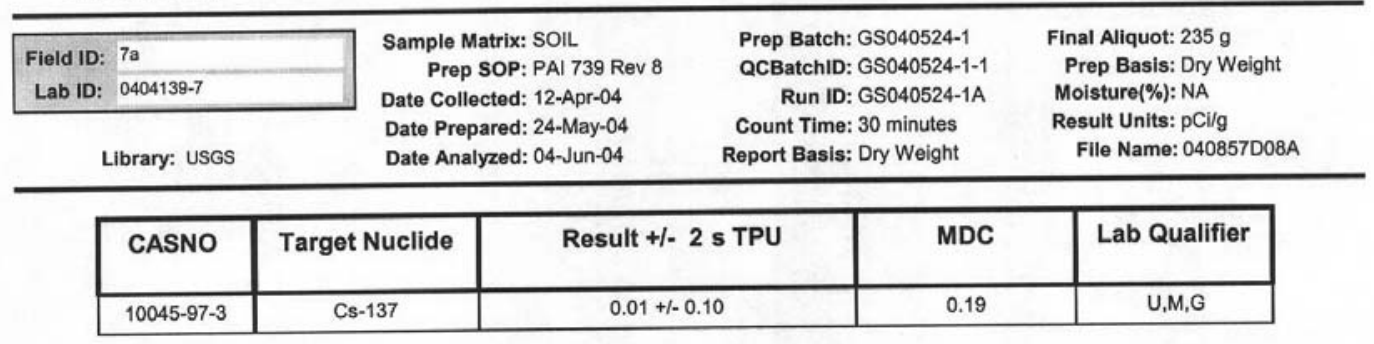

Comments:

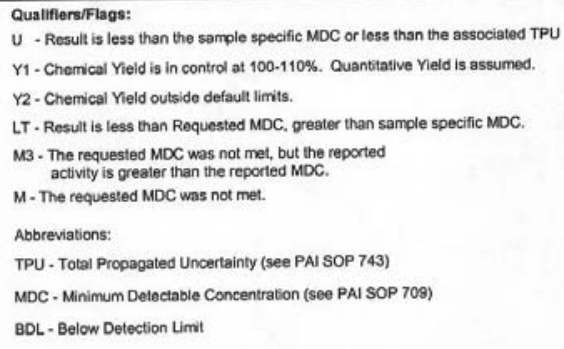

Date Printed: Thursday, June 10, 2004 


\section{Gamma Spectroscopy Results}

\section{PAI 713 Rev 8}

Lab Name: Paragon Analytics Work Order Number: 0404139

Sample Results

Client Name: ESH20_LANL

ClientProject ID: Area G Soil Surveillance Program 7H02 C34A 3 A00 0009

\begin{tabular}{|c|c|c|c|c|c|}
\hline $\begin{array}{l}\text { Field ID: } 7 \mathrm{~b} \\
\text { Lab ID: } 0404139-8\end{array}$ & \multirow{2}{*}{\multicolumn{2}{|c|}{$\begin{array}{l}\text { Sample Matrix: SOIL } \\
\text { Prep SOP: PAI } 739 \text { Rev } 8 \\
\text { Date Collected: } 13-A p r-04 \\
\text { Date Prepared: } 24-\text { May-04 } \\
\text { Date Analyzed: } 04-J u n-04\end{array}$}} & \multirow{2}{*}{\multicolumn{2}{|c|}{$\begin{array}{l}\text { Prep Batch: GS040524-1 } \\
\text { QCBatchID: GS040524-1-1 } \\
\text { Run ID: GS040524-1A } \\
\text { Count Time: } 30 \text { minutes } \\
\text { Report Basis: Dry Weight }\end{array}$}} & \multirow{2}{*}{$\begin{array}{l}\text { Final Aliquot: } 291 \mathrm{~g} \\
\text { Prep Basis: Dry Weight } \\
\text { Moisture(\%): NA } \\
\text { Result Units: pCi/g } \\
\text { Flle Name: } 040858 \mathrm{D} 08\end{array}$} \\
\hline Library: USGS & & & & & \\
\hline CASNO & Target Nuclide & \multicolumn{2}{|c|}{ Result +1- 2 s TPU } & MDC & Lab Qualifier \\
\hline $10045-97-3$ & Cs-137 & $-0.01+$ & & 0.19 & U,M,G \\
\hline
\end{tabular}

Comments:

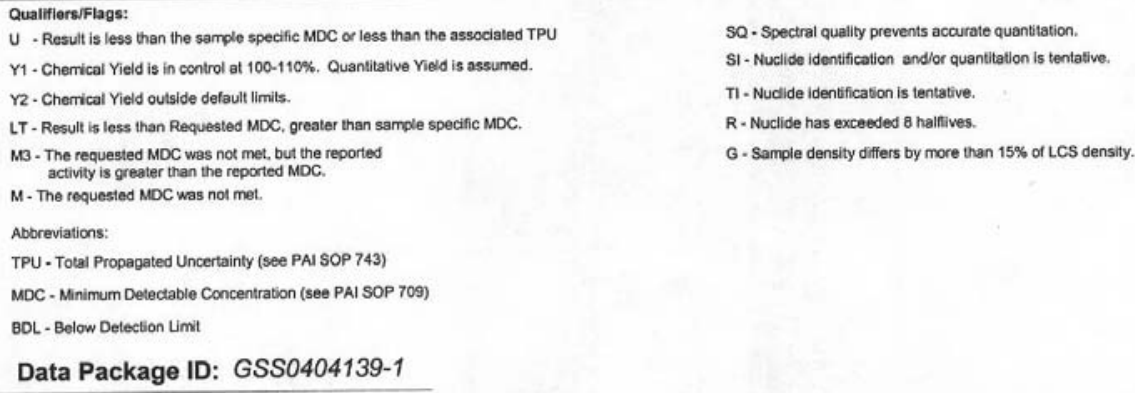

$U$ - Result is less than the sample specific MDC or less than the associated TPU

SQ - Spectral quality prevents accurate quantitation.

S1 - Nuclide identification andior quantitation is tentative.

Y2. Cherrical Yield outside default limits.

LT - Result is less than Requested MDC, greater than sample specific MDC.

M3 - The requested MDC was not met, but the reported

activils greater than hercponed MD

M- The requested MDC was not mel.

Aboreviations:

TPU - Total Propagated Uncertainty (see PAI SOP 743)

MDC - Minimum Detectable Concentration (see PAI SOP 709)

BDL - Below Detection Limit

Data Package ID: GSS0404139-1

Date Printed: Thursday, June 10, 2004 


\section{Gamma Spectroscopy Results}

PAI 713 Rev 8

Sample Results

Lab Name: Paragon Analytics Work Order Number: 0404139

Client Name: ESH20_LANL

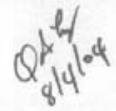

ClientProject ID: Area G Soil Surveillance Program 7H02 C34A 3 A00 0009

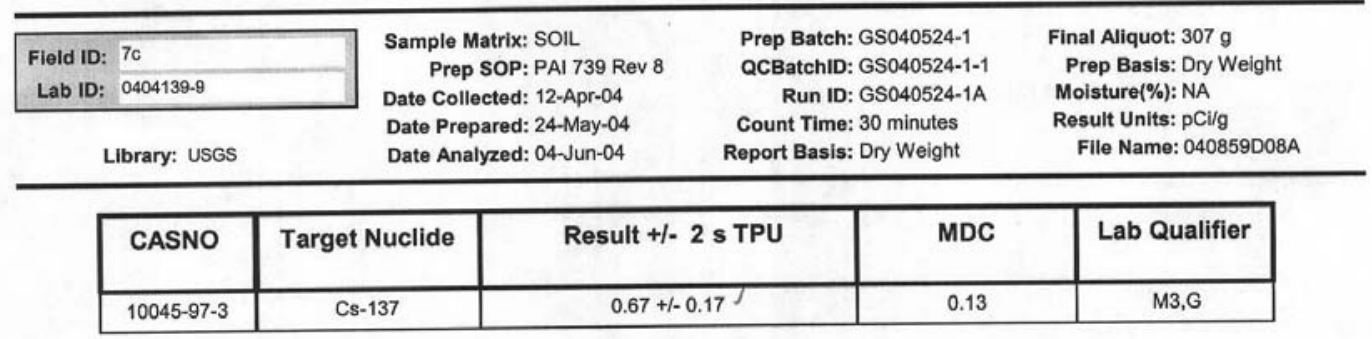

Comments:

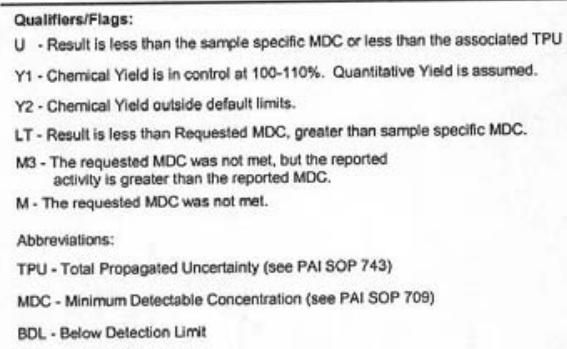

Date Printed: Thursday, June 10, 2004 


\section{Gamma Spectroscopy Results}

PAI 713 Rev 8

\section{Sample Results}

Lab Name: Paragon Analytics

Work Order Number: 0404139

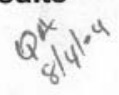

Client Name: ESH20_LANL

ClientProject ID: Area G Soil Surveillance Program 7H02 C34A 3 A00 0009

\begin{tabular}{|c|c|c|c|c|c|}
\hline $\begin{array}{l}\text { Fleld ID: } \frac{\text { G-29-03 }}{\text { Lab ID: }} \quad 0404139-10 \\
\end{array}$ & \multicolumn{2}{|c|}{$\begin{array}{l}\text { Sample Matrix: SOIL } \\
\text { Prep SOP: PAI } 739 \text { Rev } 8 \\
\text { Date Collected: } 13-\text { Apr-04 } \\
\text { Date Prepared: } 24-\text { May-04 } \\
\text { Date Analyzed: } 04-J u n-04\end{array}$} & \multicolumn{2}{|c|}{$\begin{array}{l}\text { Prep Batch: GS040524-1 } \\
\text { QCBatchID: GS040524-1-1 } \\
\text { Run ID: GS040524-1A } \\
\text { Count Time: } 30 \text { minutes } \\
\text { Report Basis: Dry Weight }\end{array}$} & $\begin{array}{l}\text { Final Aliquot: } 315 \mathrm{~g} \\
\text { Prep Basis: Dry Weight } \\
\text { Moisture(\%): NA } \\
\text { Result Units: pCi/g } \\
\text { File Name: } 040860 \mathrm{D08A}\end{array}$ \\
\hline CASNO & Target Nuclide & Result +1- & s TPU & MDC & Lab Qualifier \\
\hline $10045-97-3$ & Cs-137 & $0.16+1$ & $11 \sqrt{ }$ & 0.16 & U,M,G \\
\hline
\end{tabular}

Comments:

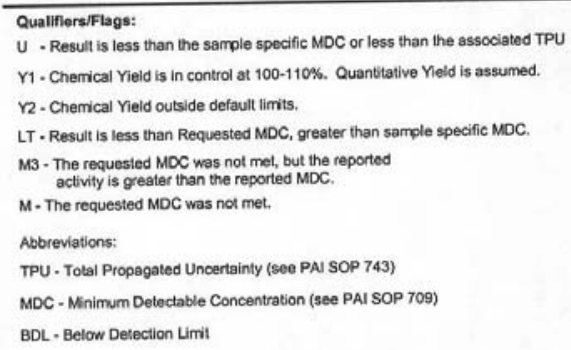

Data Package ID: GSS0404139-1

SQ - Spectral quality prevents accurate quantitation.

$\mathrm{SI}$ - Nuclide identification and/or quantitation is tentative.

TI- Nuclide identification is tentative.

R-Nuclide has exceeded 8 hallives.

G-Sample density differs by more than $15 \%$ of LCS density. 


\section{Gamma Spectroscopy Results}

PAI 713 Rev 8

Sample Results

Lab Name: Paragon Analytics

Work Order Number: 0404139

Client Name: ESH2O_LANL

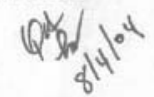

ClientProject ID: Area G Soil Surveillance Program 7H02 C34A 3 A00 0009

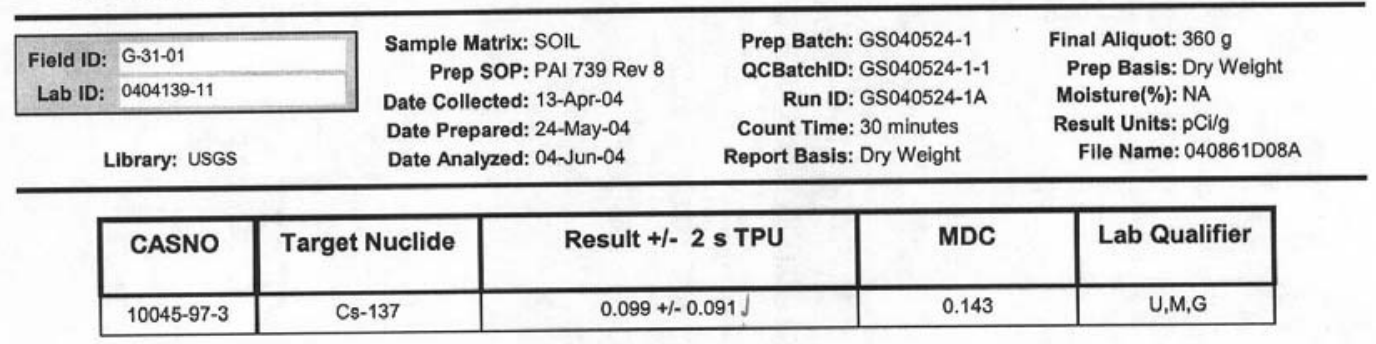

Comments:

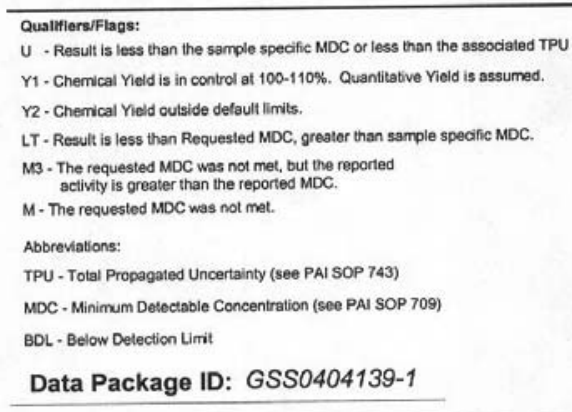

Data Package ID: GSS0404139-1

Date Printed: Thursday, June 10, 2004 


\section{Gamma Spectroscopy Results}

\section{PAI 713 Rev 8}

Sample Results

Lab Name: Paragon Analytics

Work Order Number: 0404139

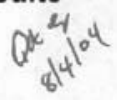

Client Name: ESH20_LANL

ClientProject ID: Area G Soil Surveillance Program 7H02 C34A 3A00 0009

\begin{tabular}{|c|c|c|c|}
\hline Field ID: G-41-02 & \multirow{4}{*}{$\begin{array}{l}\text { Sample Matrix: SOIL } \\
\text { Prep SOP: PAI } 739 \text { Rev } 8 \\
\text { Date Collected: } 12-A p r-04 \\
\text { Date Prepared: } 24-\text { May-04 } \\
\text { Date Analyzed: } 04-J u n-04\end{array}$} & \multirow{4}{*}{$\begin{array}{l}\text { Prep Batch: GS040524-1 } \\
\text { QCBatchID: GS040524-1-1 } \\
\text { Run ID: GS040524-1A } \\
\text { Count Time: } 30 \text { minutes } \\
\text { Report Basis: Dry Weight }\end{array}$} & \multirow{4}{*}{$\begin{array}{l}\text { Final Aliquot: } 380 \mathrm{~g} \\
\text { Prep Basis: Dry Weight } \\
\text { Moisture(\%): NA } \\
\text { Result Units: pCi/g } \\
\text { File Name: 040800D07A }\end{array}$} \\
\hline Lab ID: $\quad 0404139-12$ & & & \\
\hline & & & \\
\hline LIbrary: USGS & & & \\
\hline
\end{tabular}

\begin{tabular}{|c|c|c|c|c|}
\hline CASNO & Target Nuclide & Result +/- 2 s TPU & MDC & Lab Qualifier \\
\hline $10045-97-3$ & Cs-137 & $0.20+/-0.10^{\top}$ & 0.13 & M3,G \\
\hline
\end{tabular}

Comments:

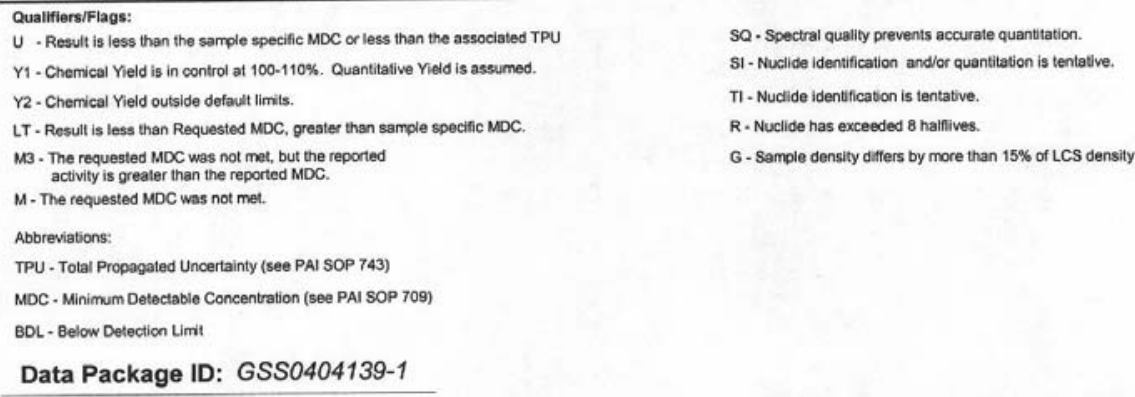

Date Printed: Thursday, June 10, 2004 


\section{Gamma Spectroscopy Results}

\section{PAl 713 Rev 8}

Sample Results or

Lab Name: Paragon Analytics

Work Order Number: 0404139

Client Name: ESH2O_LANL

ClientProject ID: Area G Soil Surveillance Program 7H02 C34A 3A00 0009

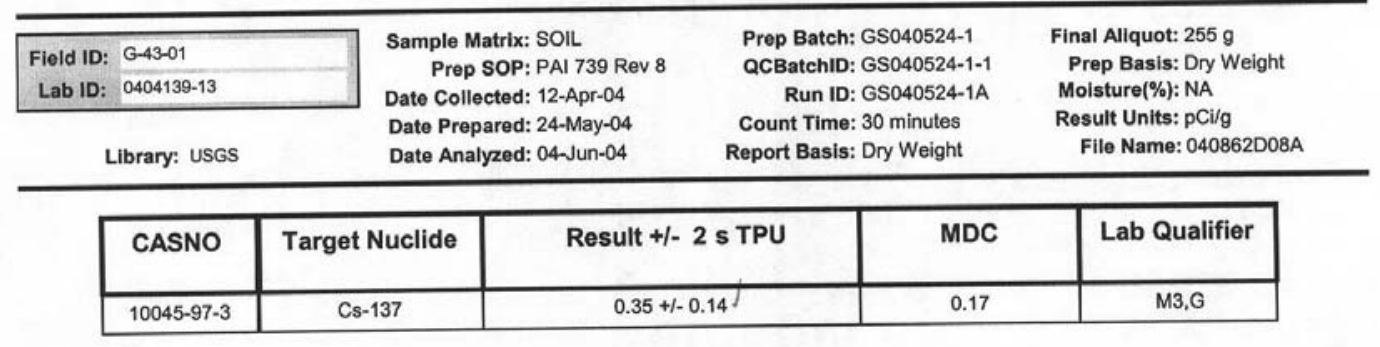

Comments:

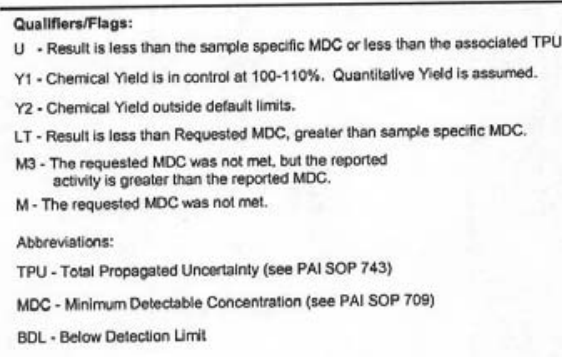

SO - Spectral quality prevents accurate quantitation.

$\mathrm{SI}$ - Nuclide Identification andior quantitation is tentative.

$\pi 1$ - Nucide identfication is tentative.

$R$ - Nuclide has exceeded 8 halfives.

G. Sample density differs by more than $15 \%$ of LCS density. 


\section{Gamma Spectroscopy Results}

\section{PAl 713 Rev 8}

Sample Results

Lab Name: Paragon Analytics Work Order Number: 0404139 Client Name: ESH20_LANL

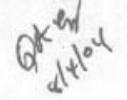

ClientProject ID: Area G Soil Surveillance Program 7H02 C34A 3 A00 0009

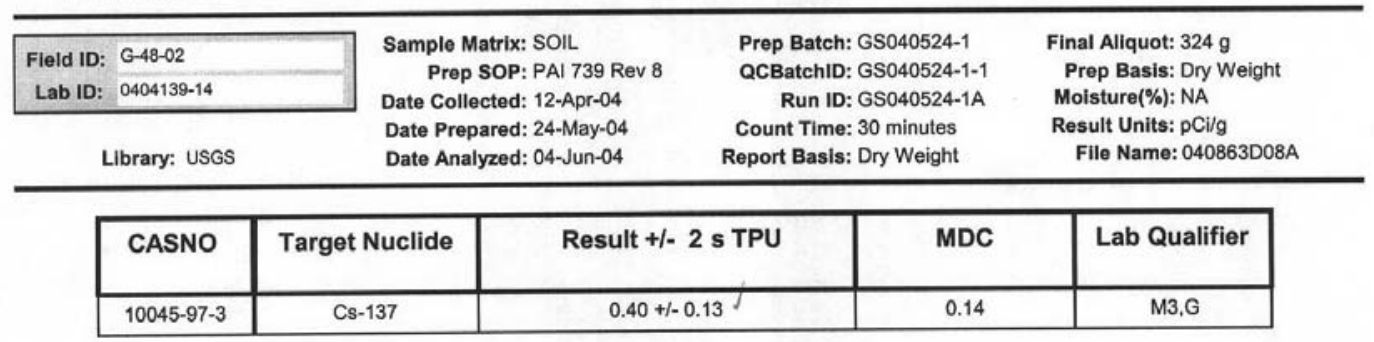

Comments:

\section{Qualifiers/Flags:}

$U$ - Result is less than the sample specific MDC or less than the associated TPU

$\mathrm{Y} 1$. Chemical Yield is in control at 100-110\%. Quantitative Vield is assumed.

Y2. Cherrical Yield outside default limits.

LT - Result is less than Requested MDC, greater than sample specific MDC.

M3 - The requested MDC was not met, but the reported

M. Thetivity is grester than the reponted MDC.

$M$ - The requested MDC was not met.

Abbreviations:

TPU - Total Propagated Uncertainty (see PAI SOP 743)

MDC - Minimum Detectable Concentration (see PAI SOP 709)

BDL - Below Detection Uimit

Data Package ID: GSS0404139-1
Date Printed: Thursday, June 10, 2004
Paragon Analytics LIMS Version: $5.029 \mathrm{~A}$

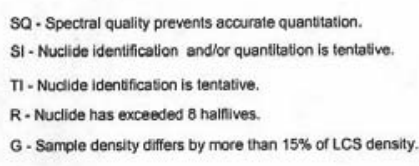

SQ - Spectral quality prevents accurate quantitation.

SI - Nuclide identification and/or quantitation is tentative.

$\pi 1$ - Nudide idenufication is tentative.

R - Nuclide has exceeded 8 halinives.

G. Sample density differs by more than $15 \%$ of LCS density.

LIMS Version: $5.029 \mathrm{~A}$

Page 14 of 16

000026 


\section{Gamma Spectroscopy Results}

\section{PAI 713 Rev 8}

Sample Results ${ }_{\text {end }}$

Lab Name: Paragon Analytics

Work Order Number: 0404139

Client Name: ESH20_LANL

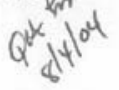

ClientProject ID: Area G Soil Surveillance Program 7H02 C34A 3A00 0009

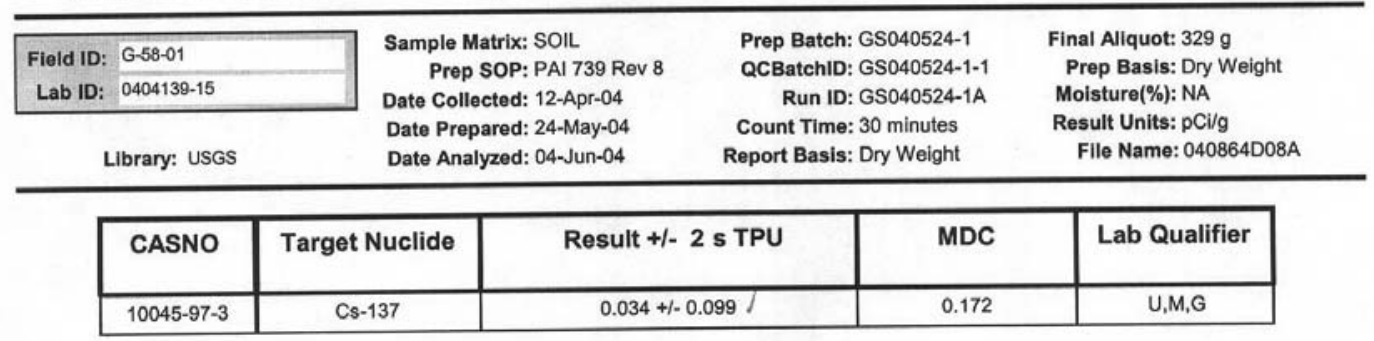

Comments:

\begin{tabular}{|c|c|}
\hline \multicolumn{2}{|l|}{ Qualifiers/Flags: } \\
\hline U - Result is less than the sample specific MDC of less than the aseociated TPU & SQ - Spectral quality prevents accurate quantitation. \\
\hline Y1 - Chemical Yeld is in control at 100-110\%. Quantitative Yield is assumed. & S1- Nuclide identification andior quantitation is tentative. \\
\hline Y2-Chemical Yeild outside delault limits. & $\pi \cdot$. Nuclide identification is tentative. \\
\hline LT - Result is less than Requested MDC, greater than sample specific MDC. & $R$ - Nuclide has exceeded 8 halfives. \\
\hline $\begin{array}{l}\text { M3 - The requestod MDC was not met, but the reported } \\
\text { aclivity is greater than the reported MDC. }\end{array}$ & G. Sample density differs by more than $15 \%$ of LCS density. \\
\hline \multicolumn{2}{|l|}{$M$ - The requested MDC was not mat. } \\
\hline \multicolumn{2}{|l|}{ Abbreviations: } \\
\hline \multicolumn{2}{|l|}{ TPU - Total Propogated Uncertainty (see PAI SOP 743) } \\
\hline \multicolumn{2}{|l|}{ MDC - Minimum Delectable Concentration (see PAI SOP 709) } \\
\hline \multicolumn{2}{|l|}{ BDL - Below Detection Limit } \\
\hline Data Package ID: GSS0404139-1 & \\
\hline
\end{tabular}

Date Printed: Thursday, June 10, $2004 \quad$ Paragon Analytics

Page 15 of 16

000027 


\section{Gamma Spectroscopy Results}

PAI 713 Rev 8

Lab Name: Paragon Analytics

Work Order Number: 0404139

Sample Results $\mathrm{f}$

$$
0_{81}^{x} 10^{4}
$$

Client Name: ESH20_LANL

ClientProject ID: Area G Soil Surveillance Program 7H02 C34A 3 A00 0009

\begin{tabular}{|l|}
\hline Fleld ID: 8 \\
Lab ID: $0404139-16$ \\
\hline
\end{tabular}

Sample Matrix: SOIL Prep SOP: PAI 739 Rev 8

Date Collected: 12-Apr-04

Date Prepared: 24-May-04 Date Analyzed: 04-Jun-04
Prep Batch: GS040524-1 QCBatchID: GS040524-1-1 Run ID: GS040524-1A

Count Time: 30 minutes Report Basis: Dry Weight
Final Aliquot: 364

Prep Basis: Dry Weight

Moisture(\%): NA

Result Units: $\mathrm{pCl} / \mathrm{g}$ File Name: 040865D08A

Library: USGS

Result +/- 2 s TPU

\begin{tabular}{|c|c|c|c|c|}
\hline CASNO & Target Nuclide & Result +1- 2 s TPU & MDC & Lab Qualifier \\
\hline $10045-97-3$ & Cs-137 & $0.37+1-0.13 /$ & 0.15 & M3,G \\
\hline
\end{tabular}

Comments:

Qualifiers/Flags:

U - Result is less than the sample specific MDC or less than the associated TPU

Y1 - Chemical Yield is in control at 100-110\%. Quantitative Yield is assumed.

Y2 - Chemical Yield outside default limits.

LT - Result is less than Requested MDC, greater than sample specific MDC.

M3 - The requested MDC was not met, but the reported

activity is greater than the reported MDC.

Abbreviations:

TPU - Total Propagated Uncertainty (see PAI SOP 743)

MDC - Minimum Detectable Concentration (see PAI SOP 709)

BOL-Below Detection Limit

Data Package ID: GSS0404139-1
Date Printed: Thursday, June 10, 2004

Paragon Analytics

LIMS Version: $5.029 \mathrm{~A}$
SQ - Spectral quality prevents accurate quantitation.

SI - Nuclide identification and/or quantitation is tentative.

$\mathrm{T}$ - Nuclide identification is tentative.

$R$ - Nuclide has exceeded 8 halfilives.

G - Sample density differs by more than $15 \%$ of LCS densily. 

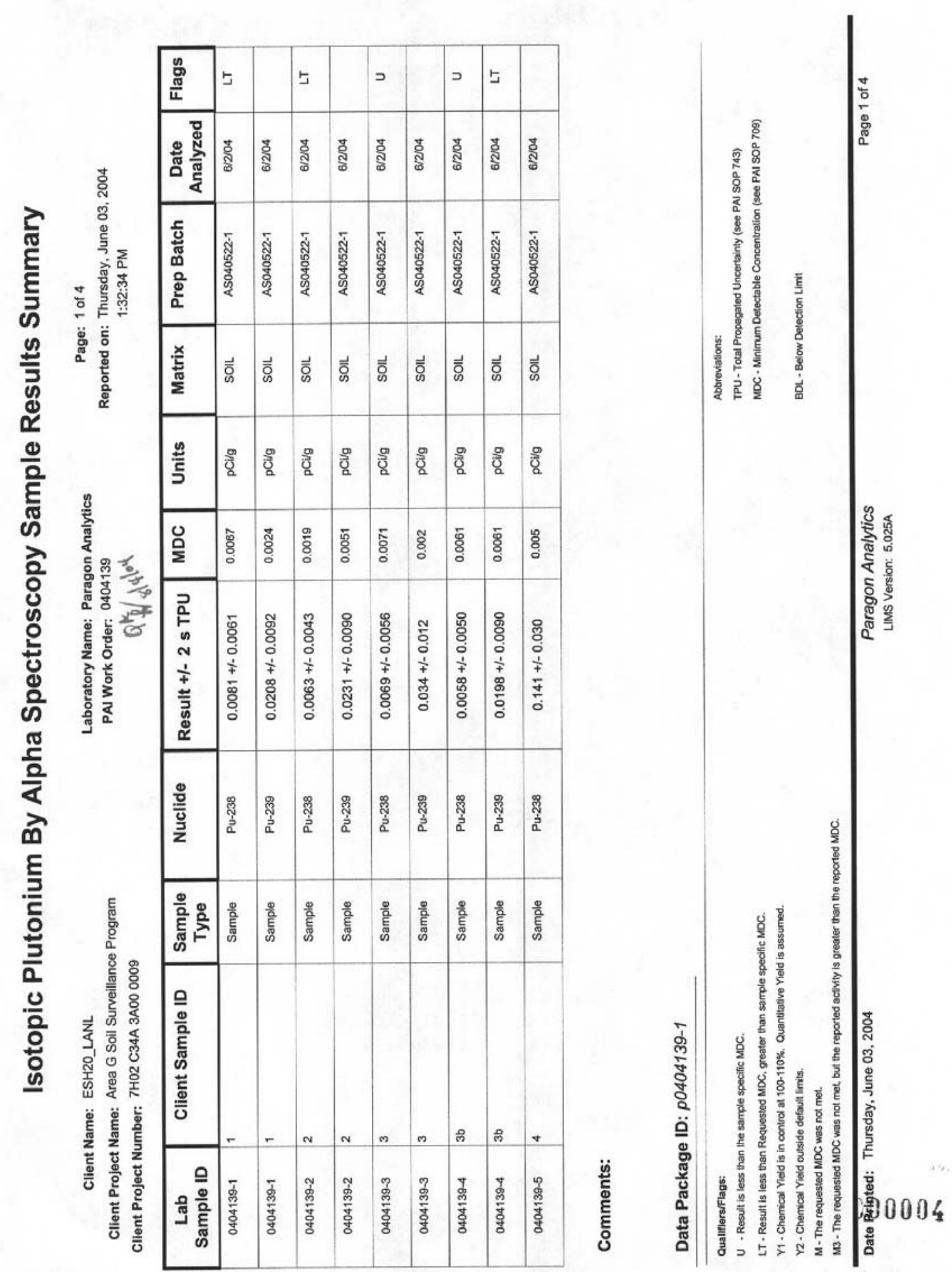

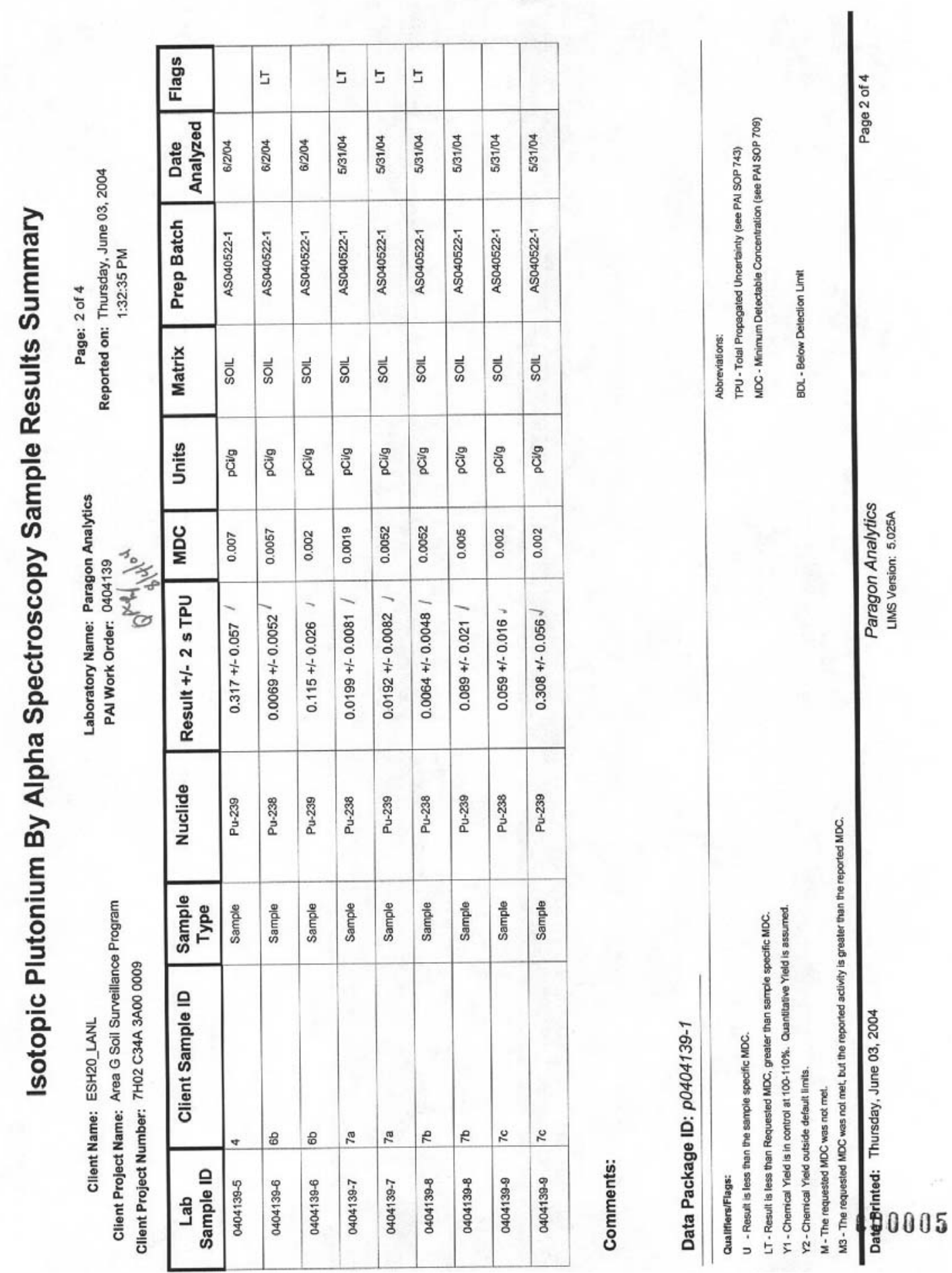

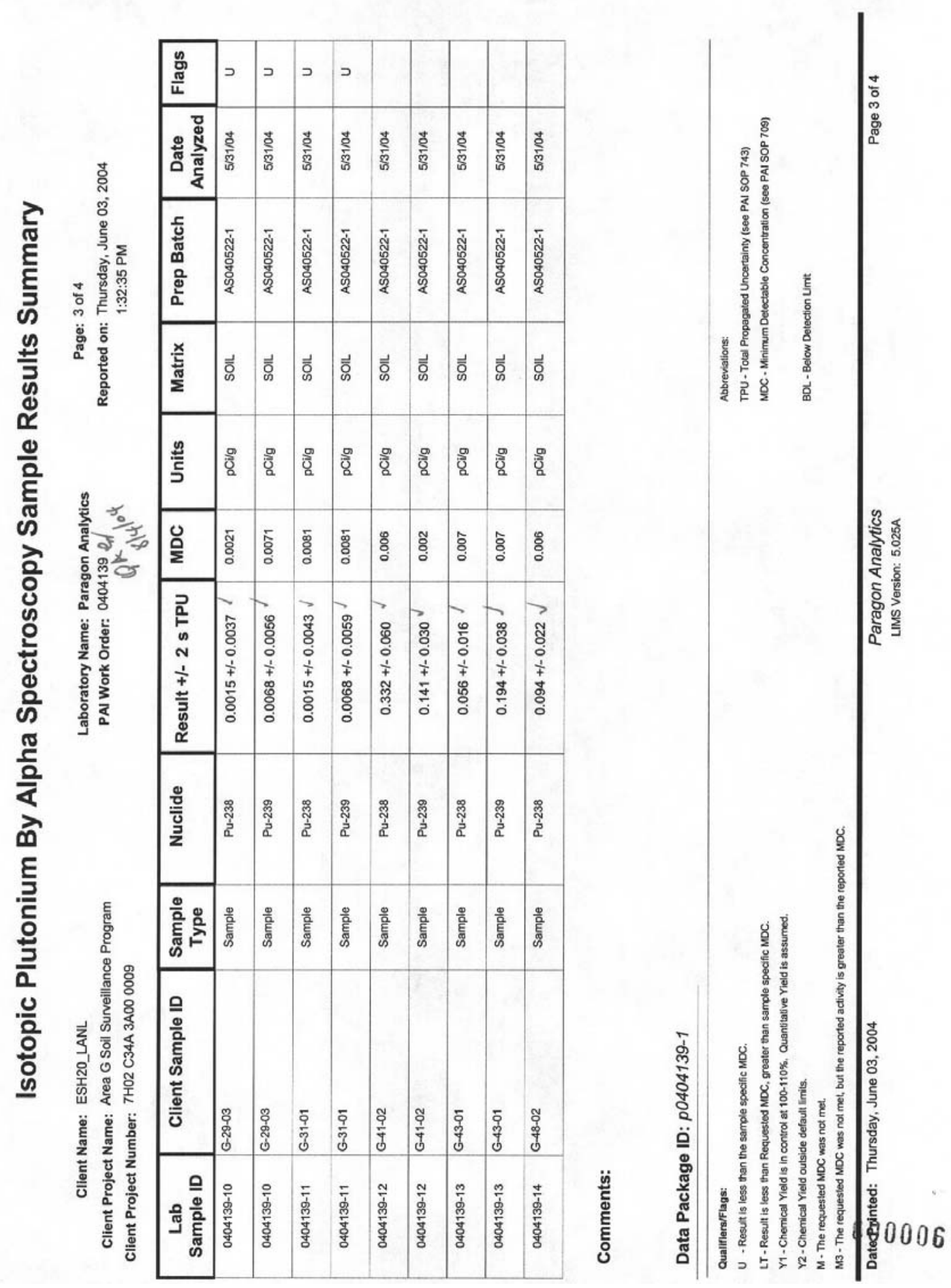

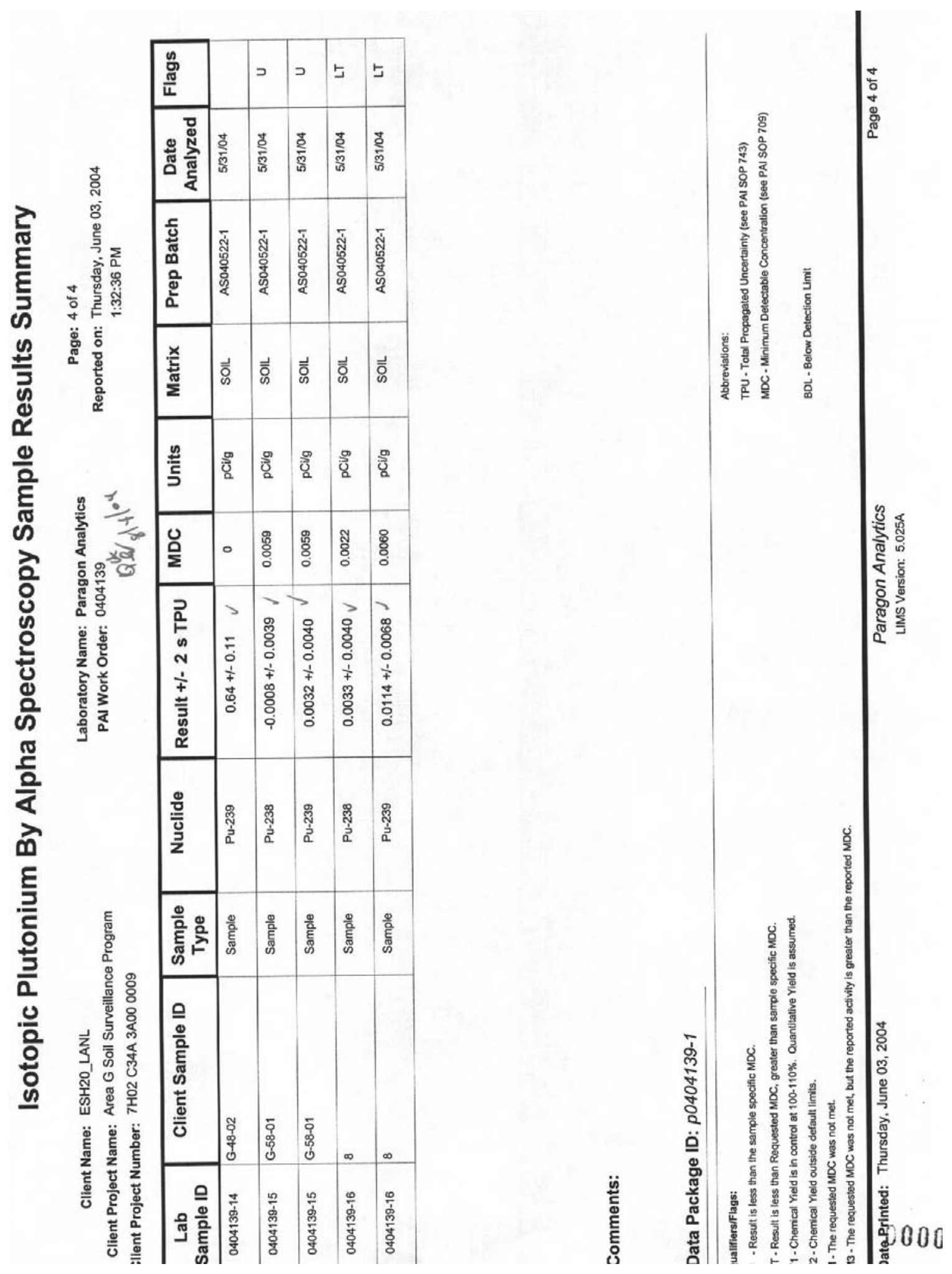

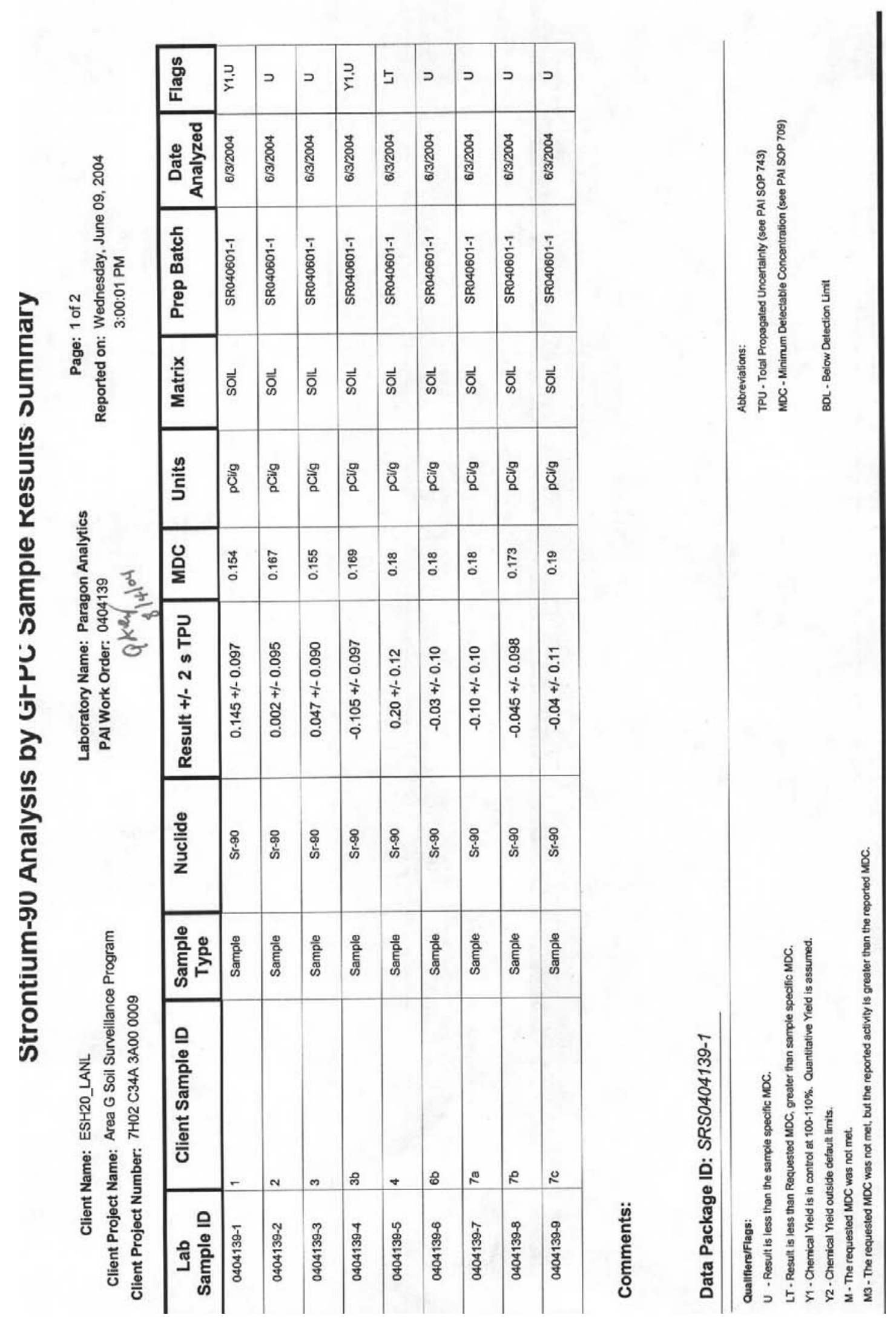

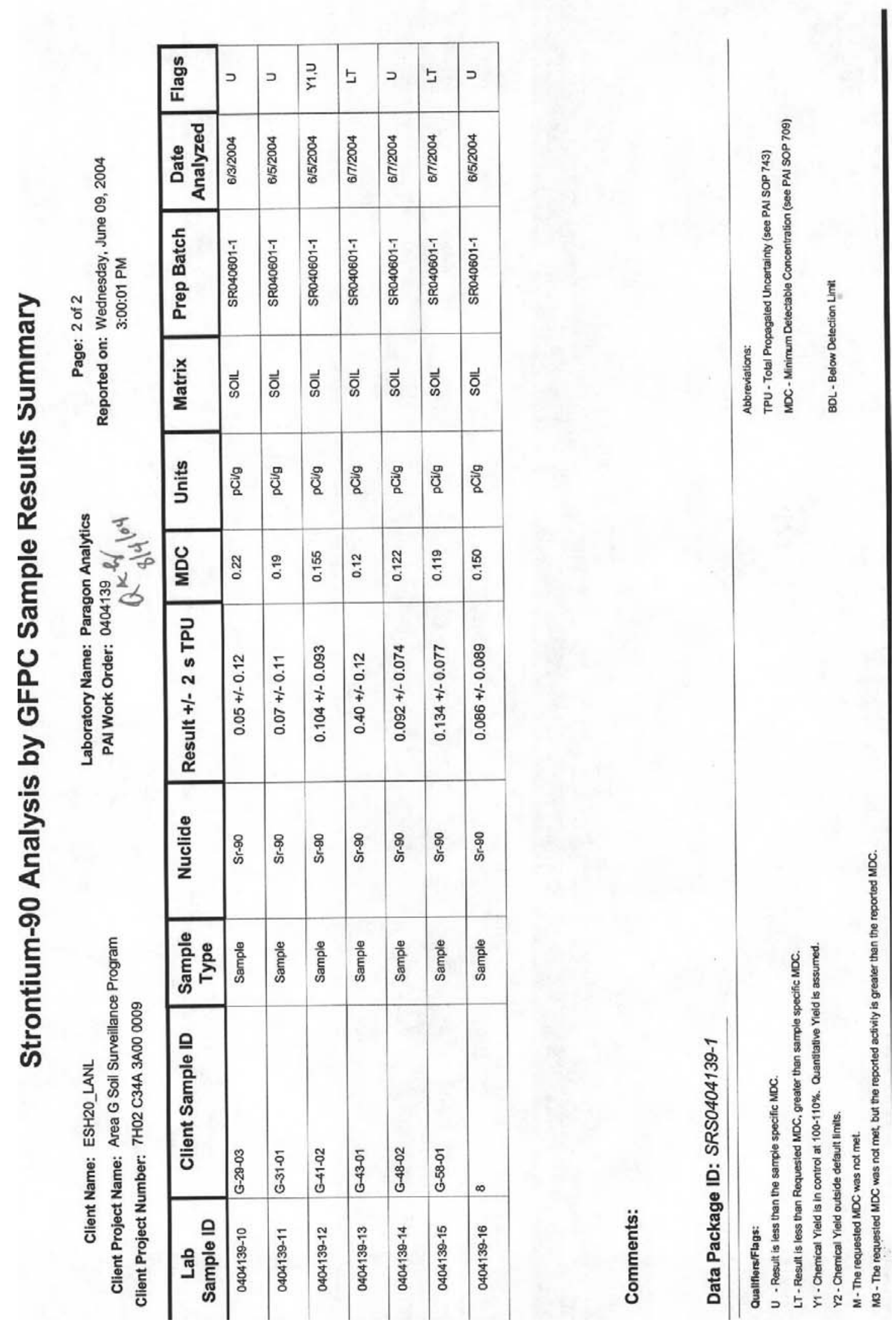

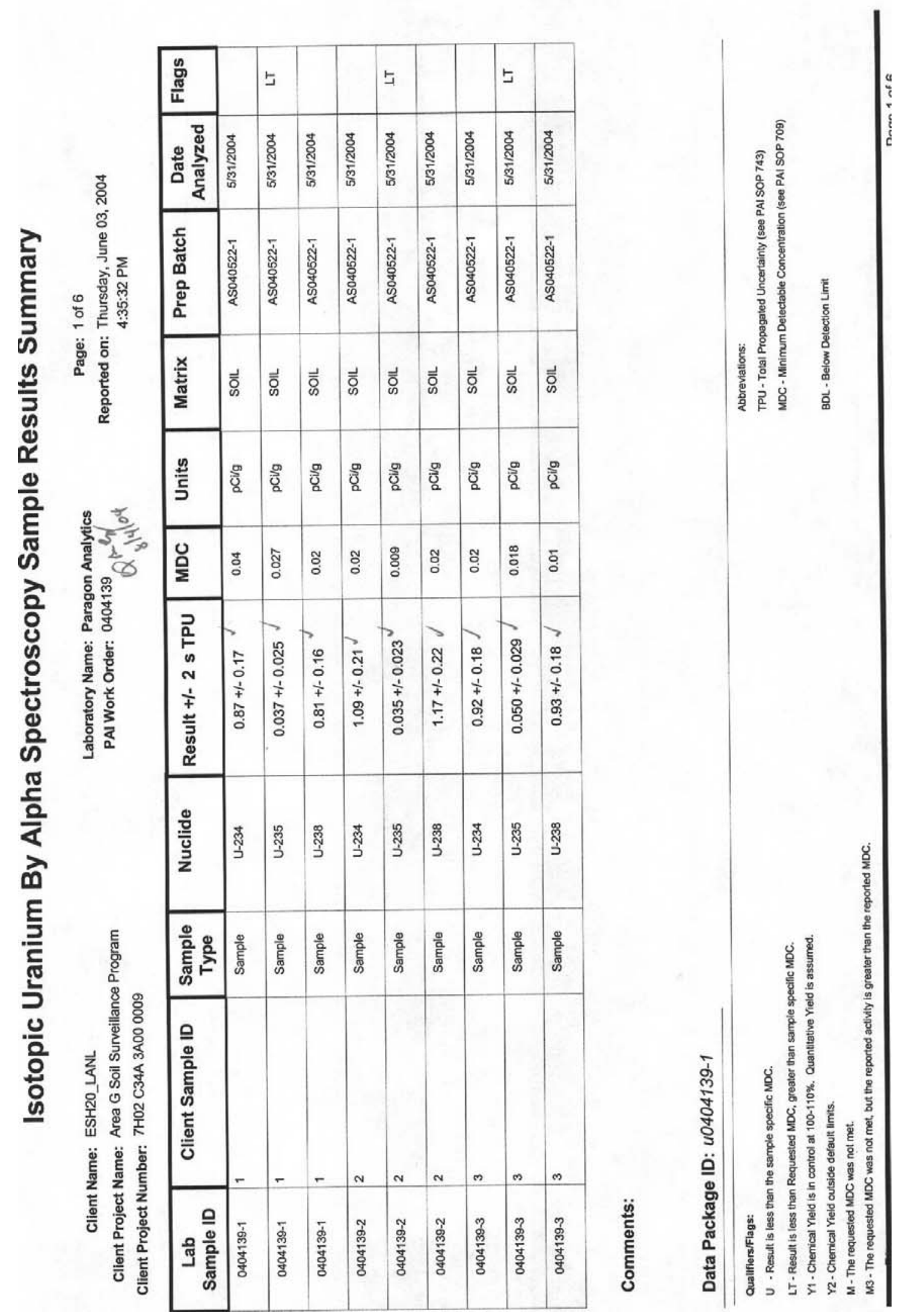


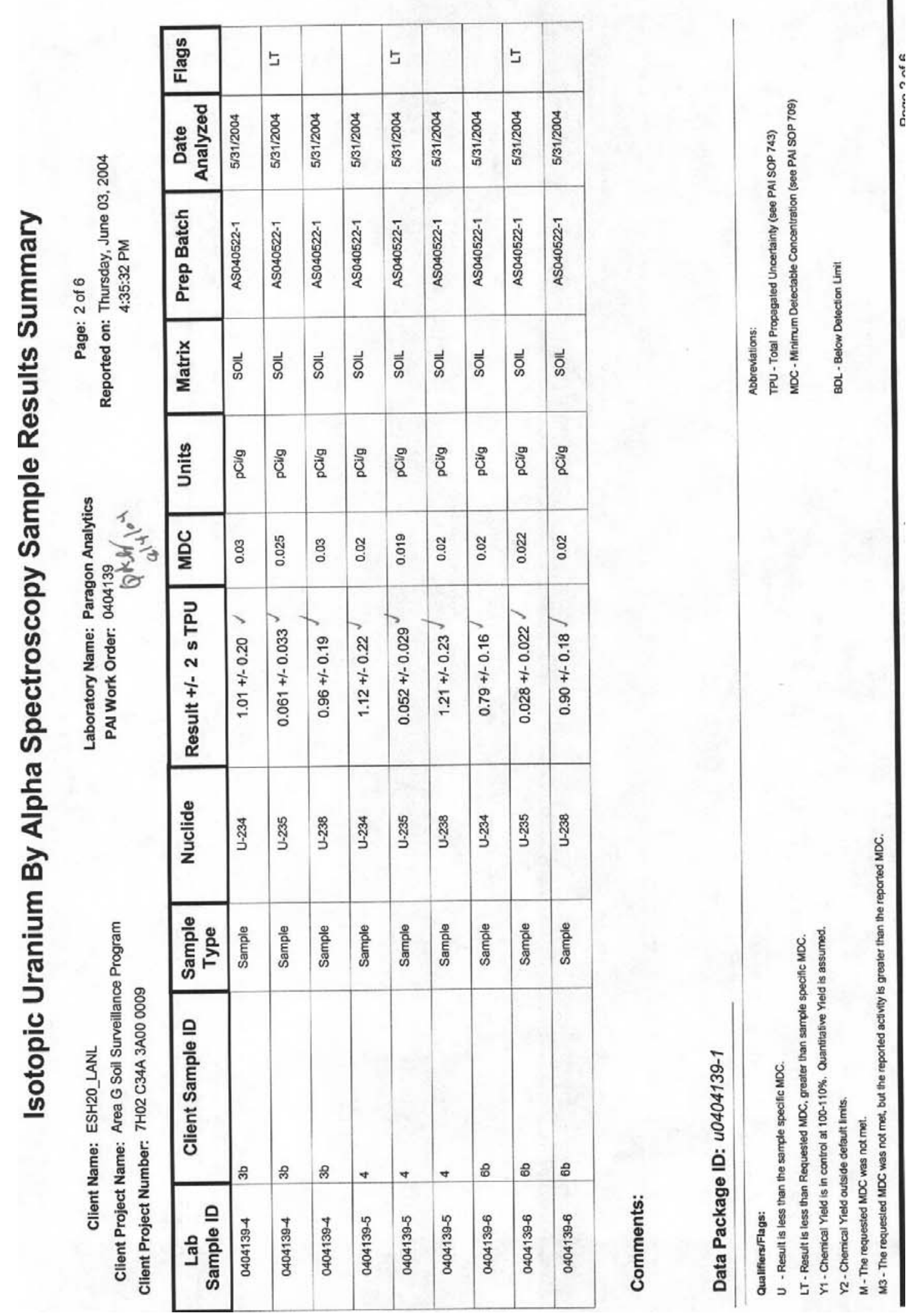



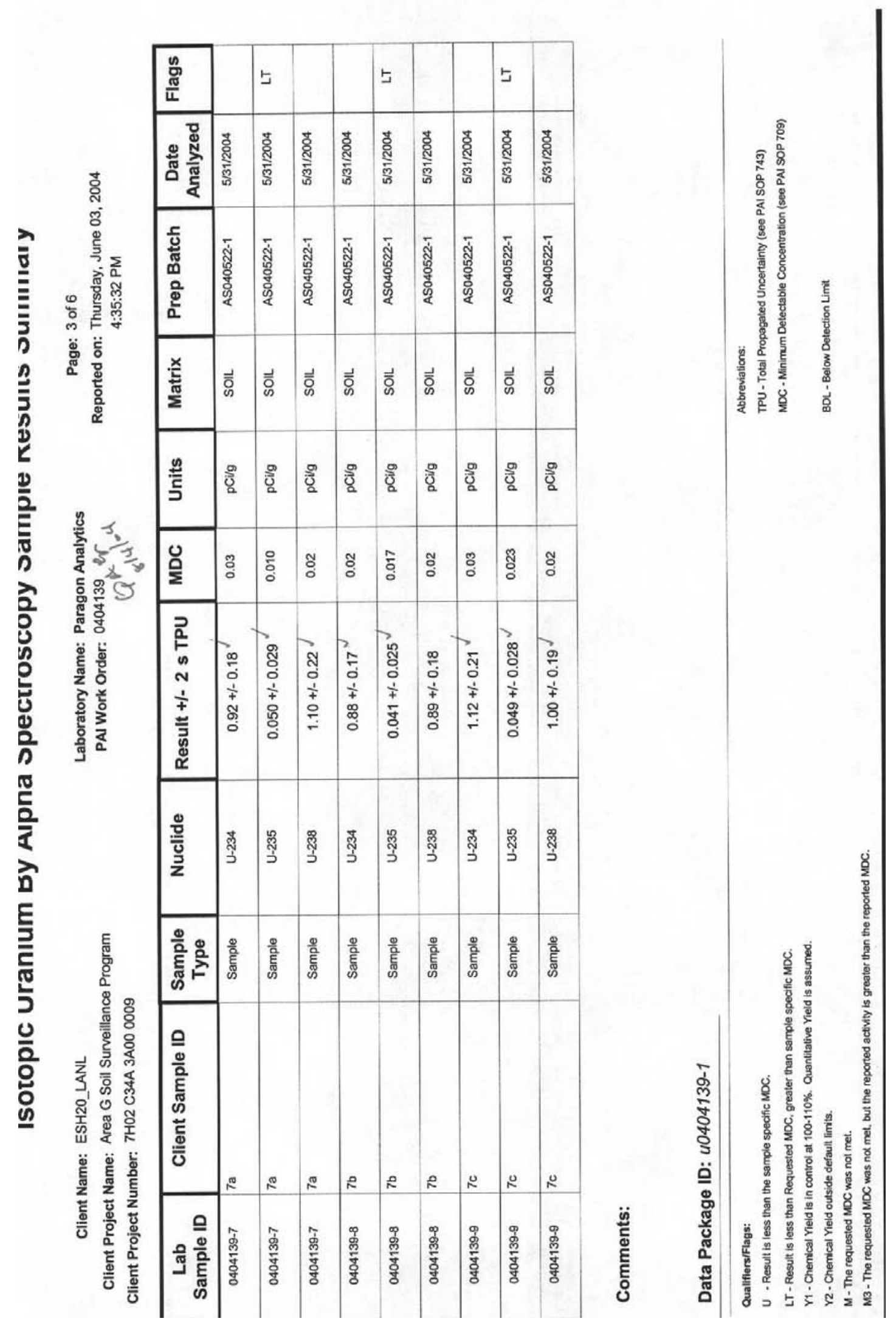

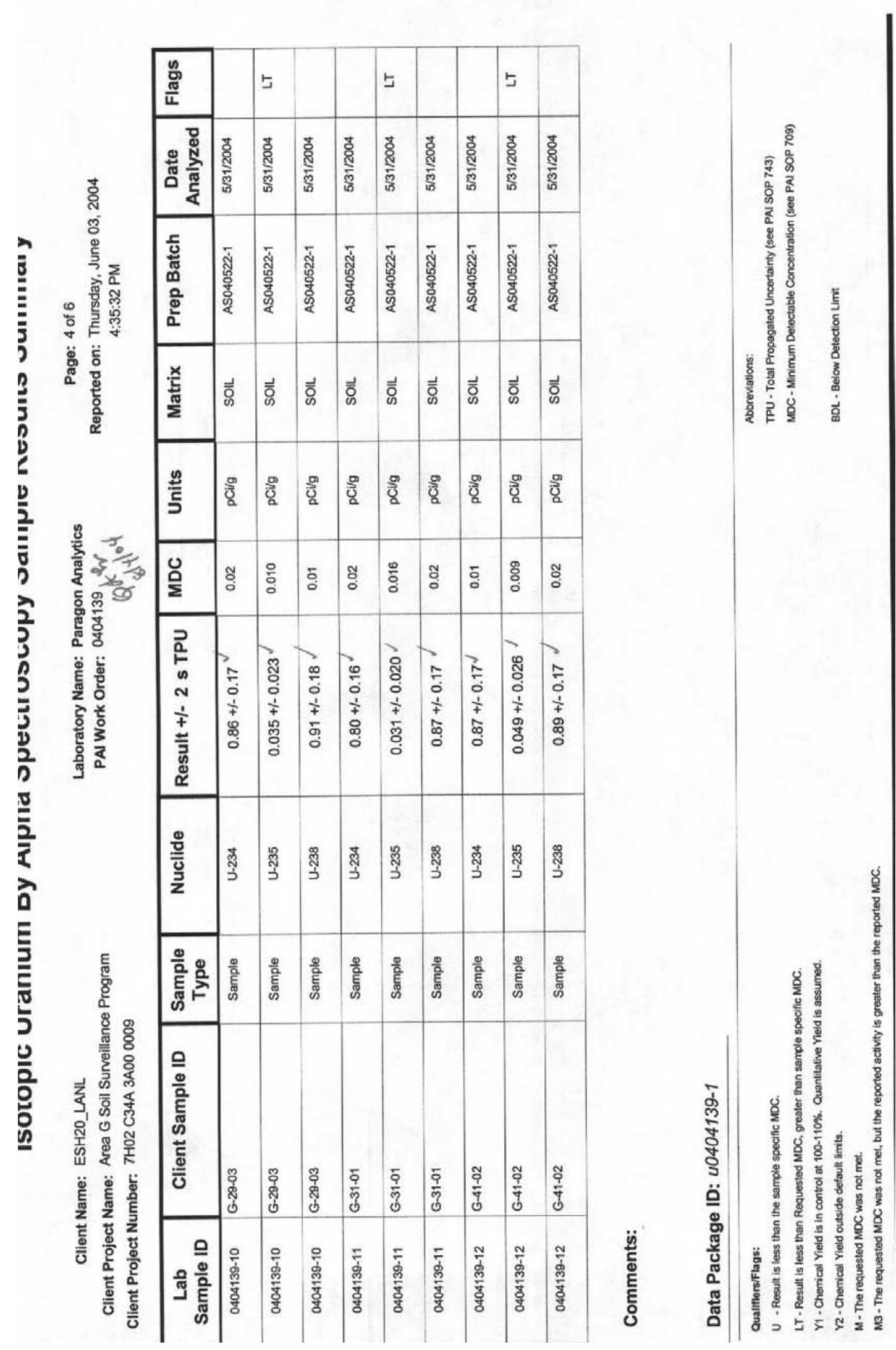

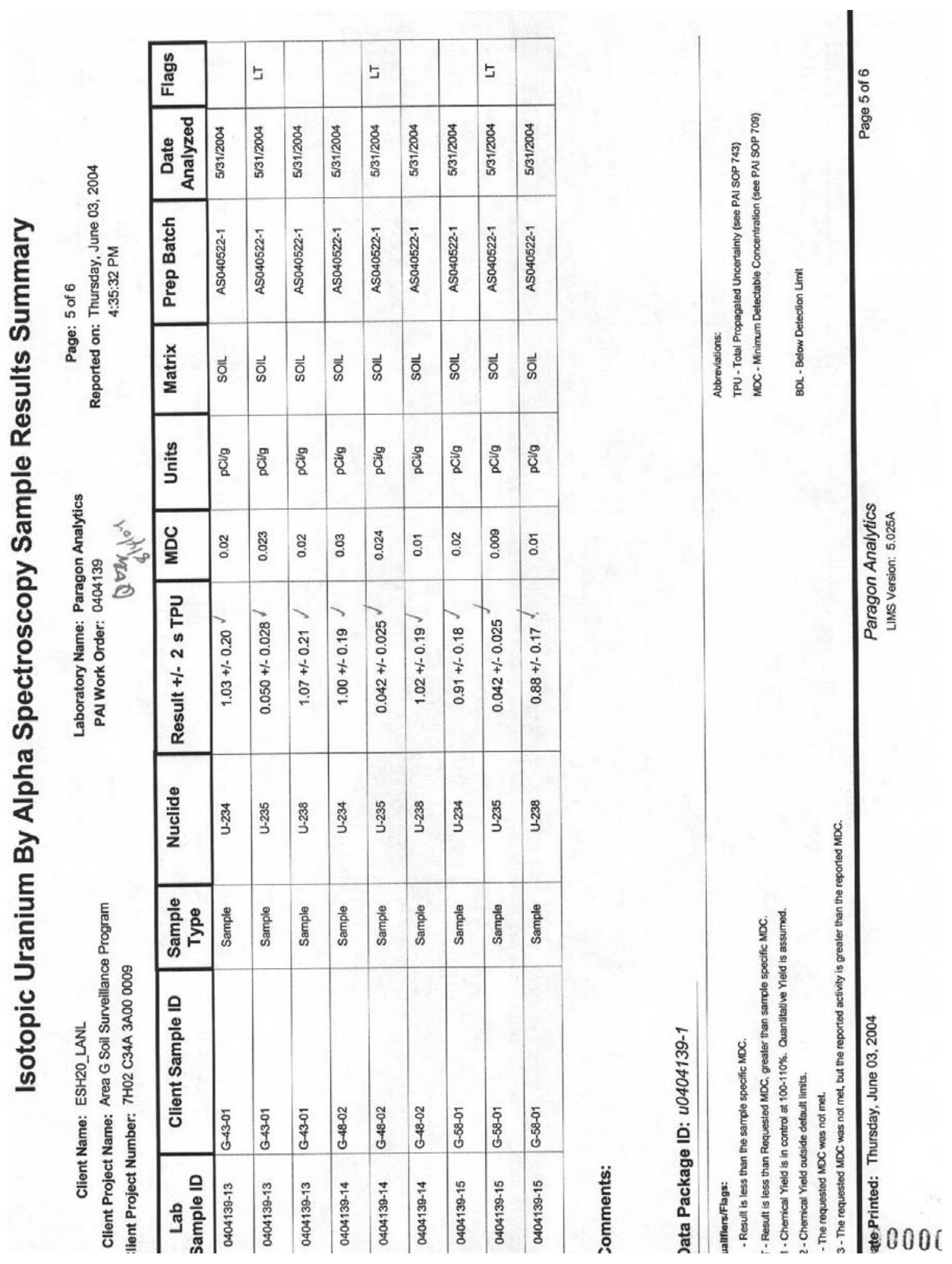

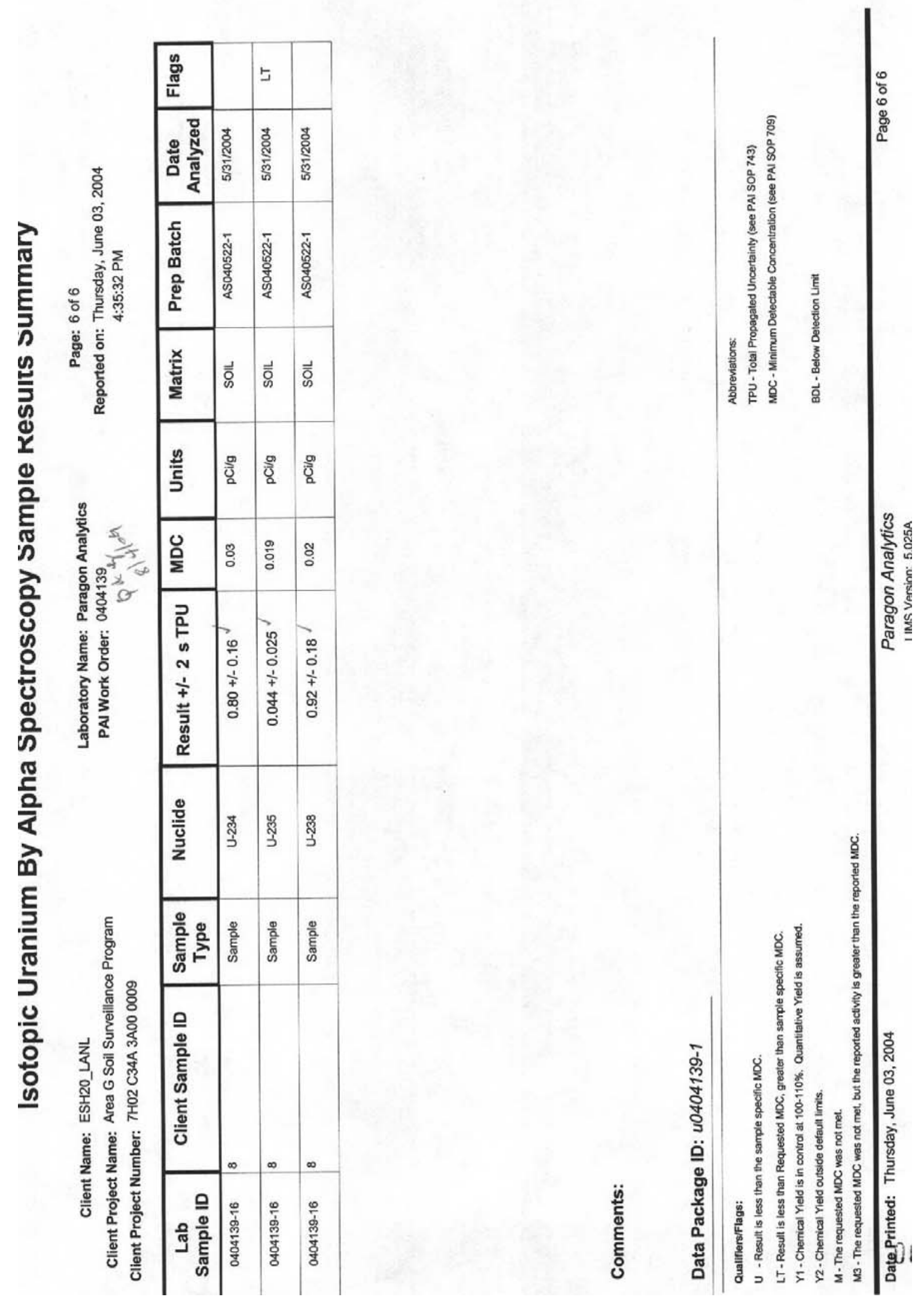


\section{APPENDIX B}

ANALYTICAL DATA REPORTS OF RADIONUCLIDE CONCENTRATIONS IN OVERSTORY AND UNDERSTORY VEGETATION COLLECTED AT AREA G DURING 2004 


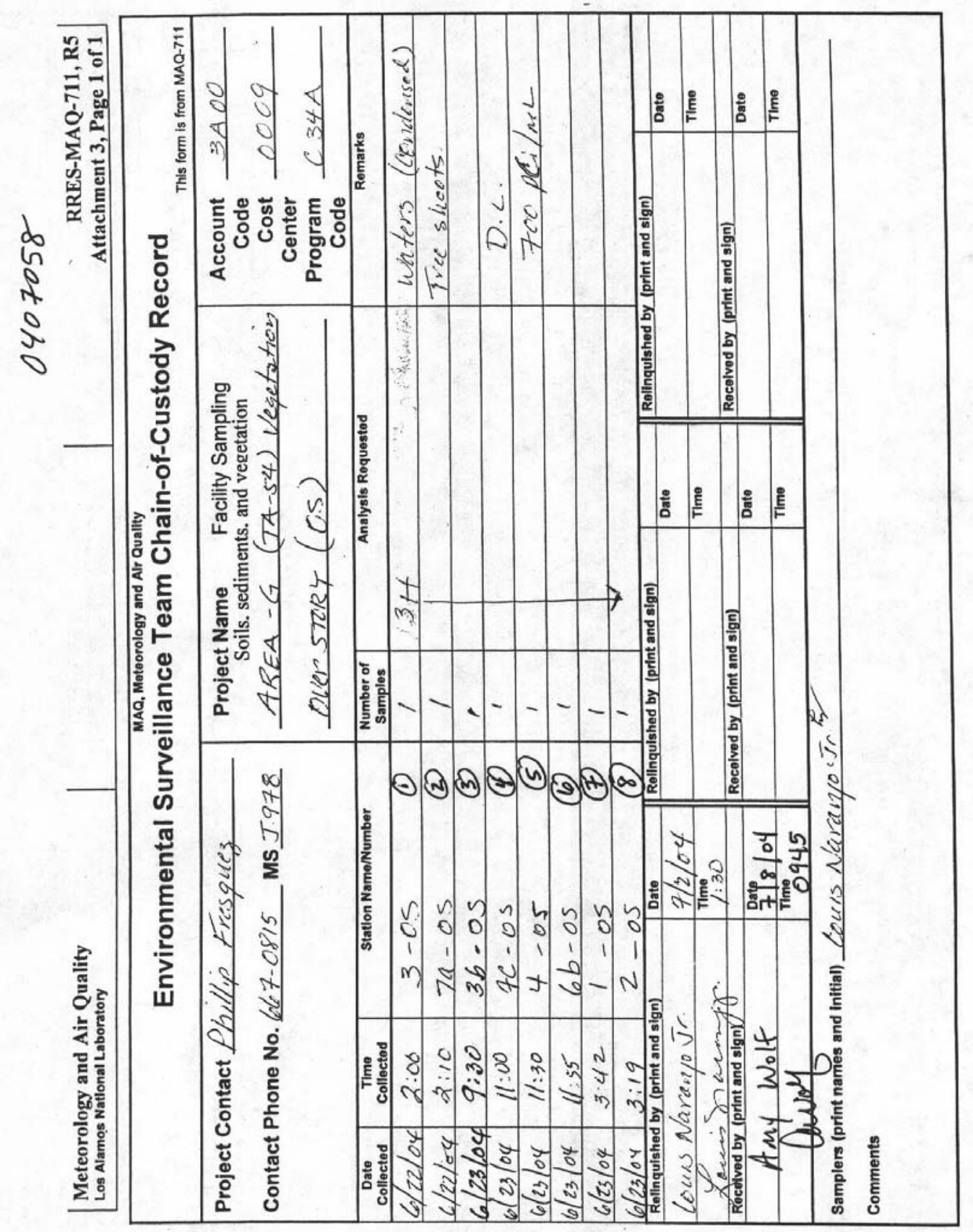




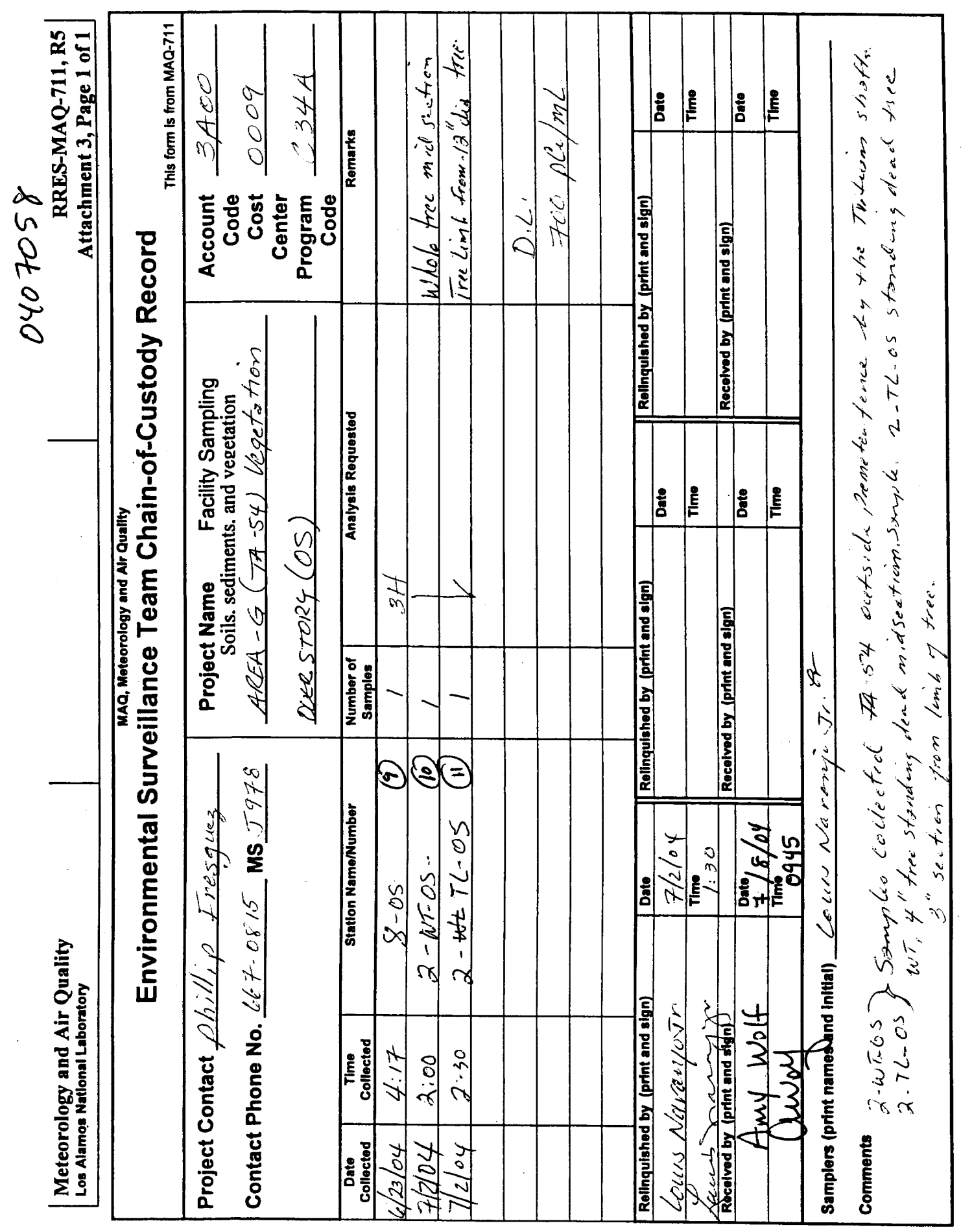



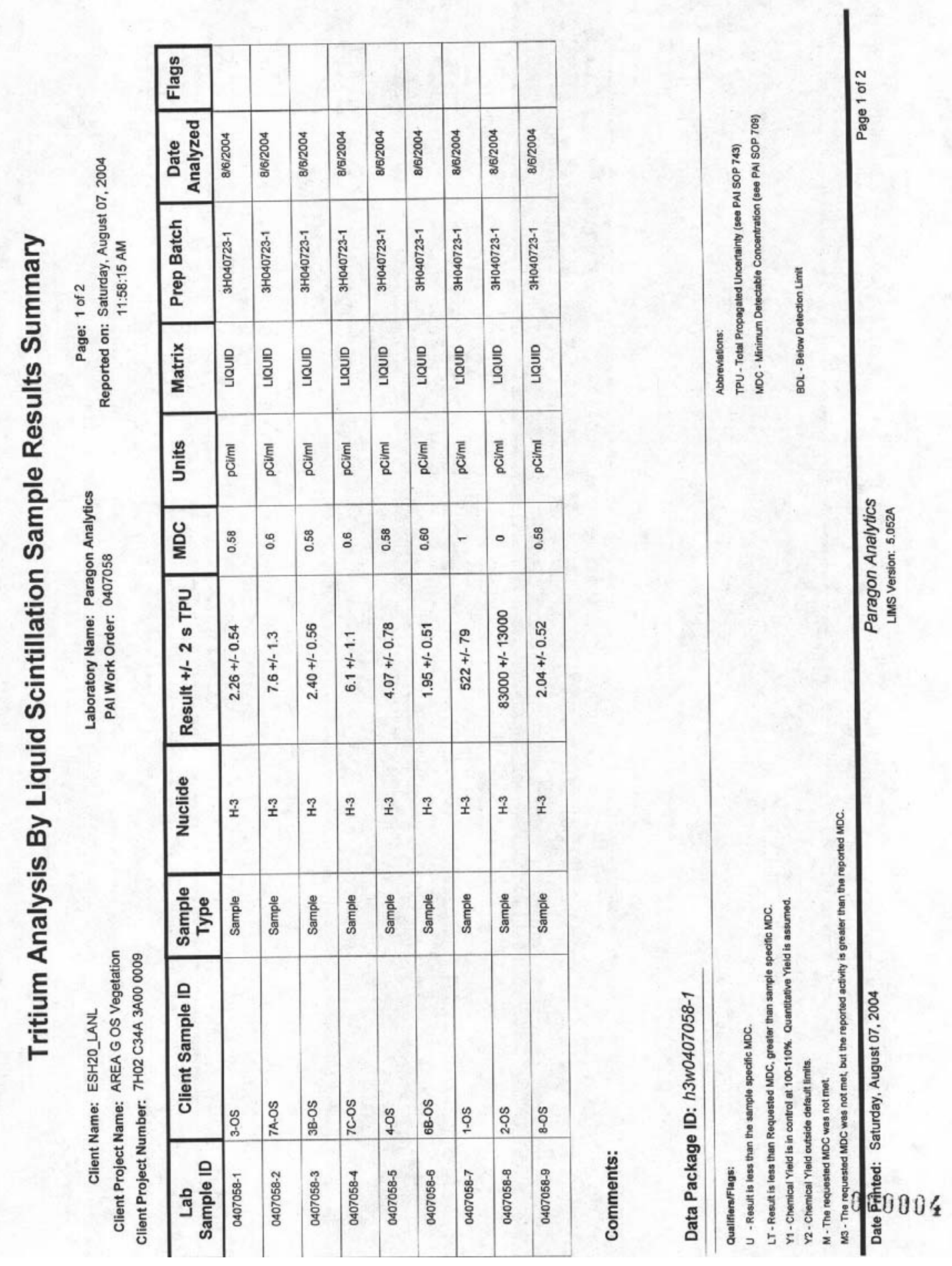

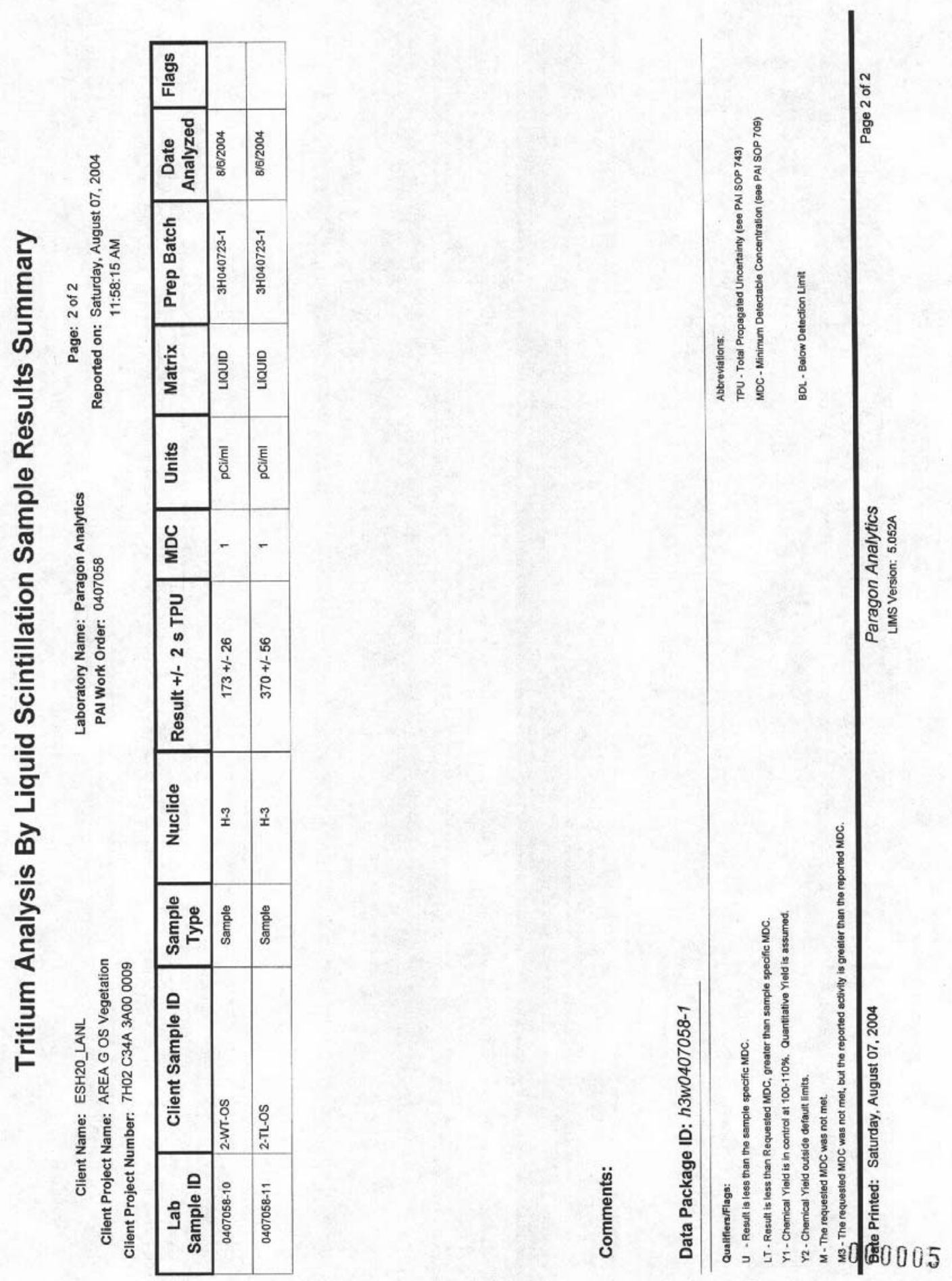


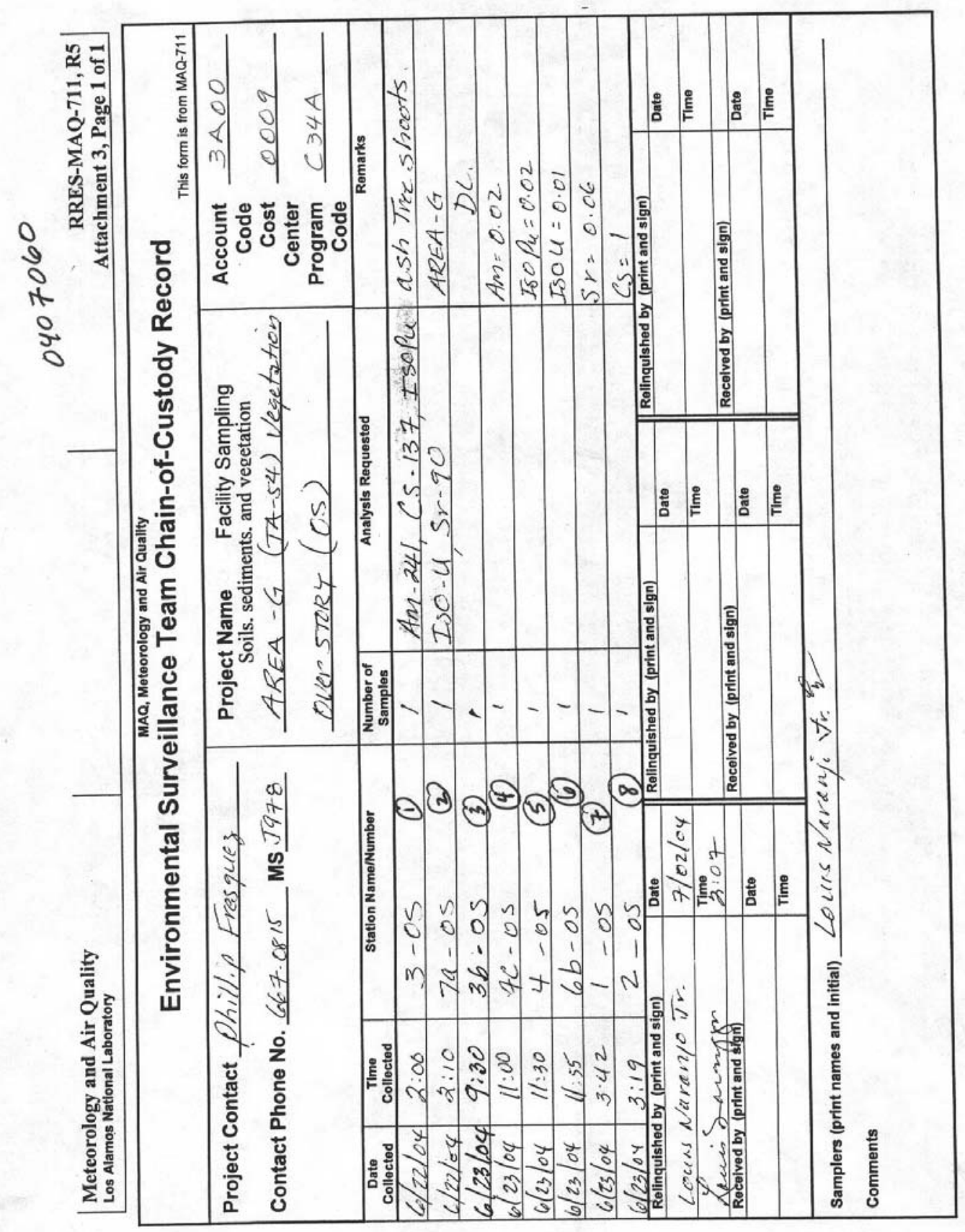




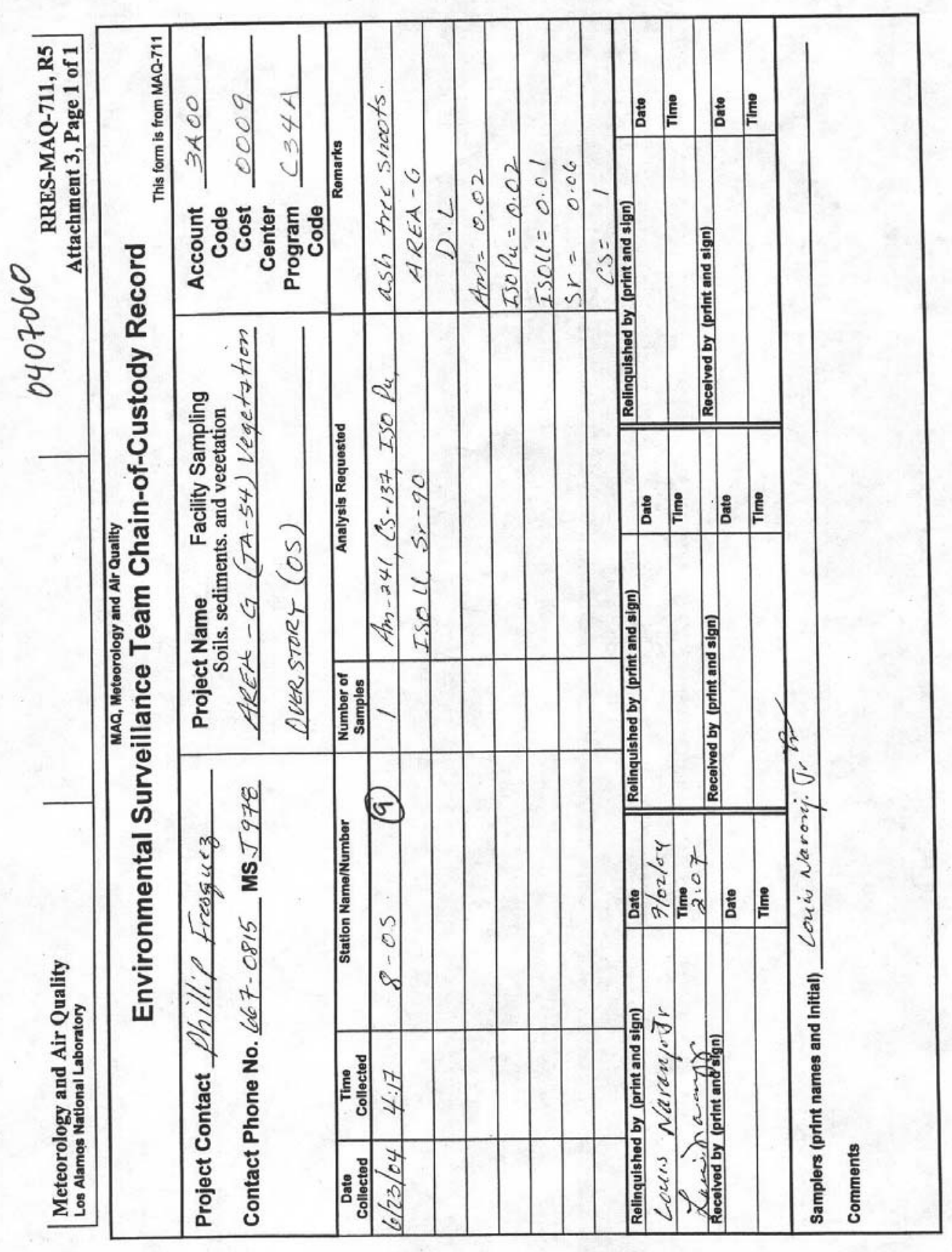



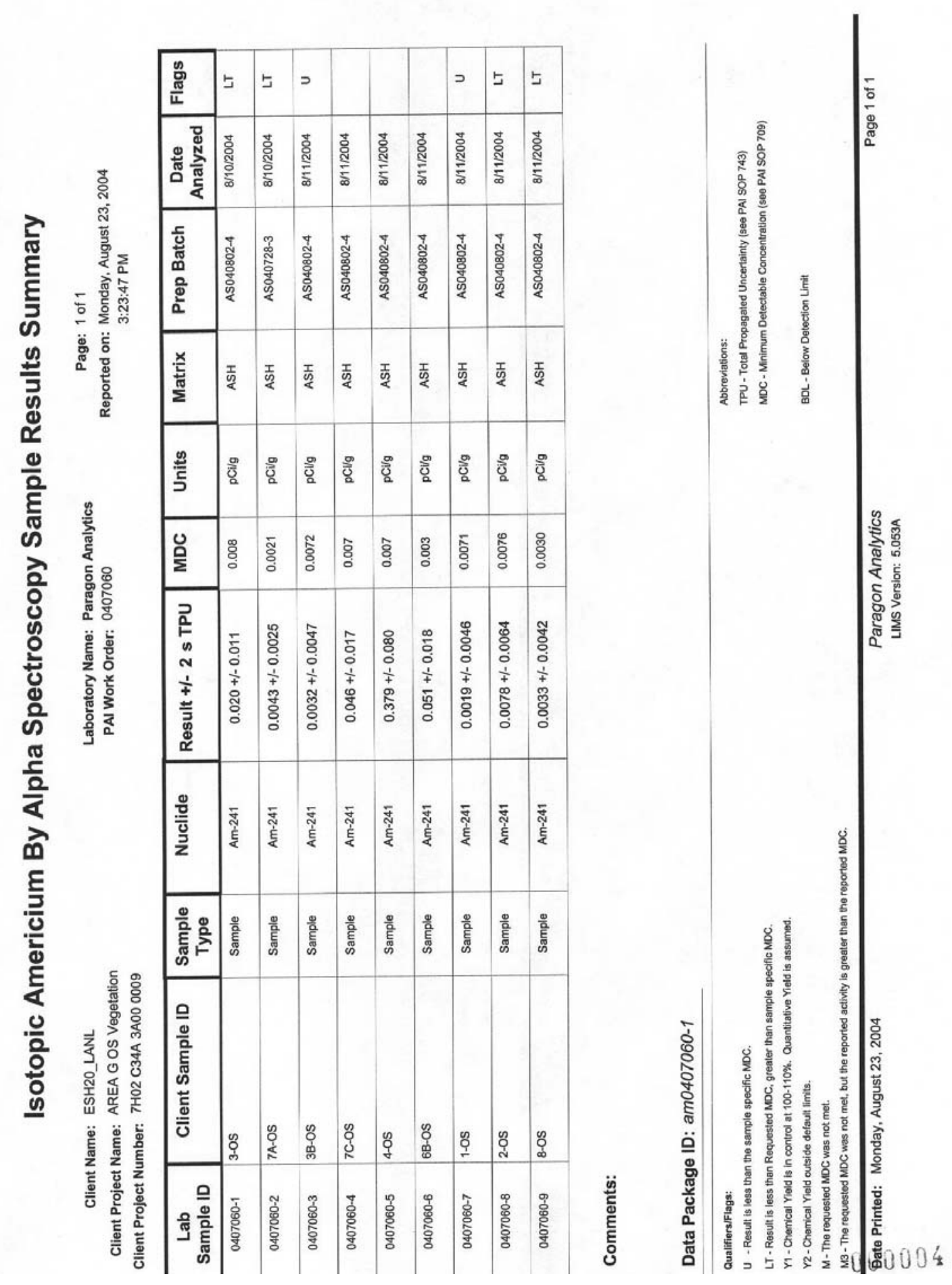


\section{Gamma Spectroscopy Results \\ PAI 713 Rev 8 \\ Sample Results}

Lab Name: Paragon Analytics

Work Order Number: 0407060

Client Name: ESH20_LANL

ClientProject ID: AREA G OS Vegetation 7H02 C34A 3 A00 0009

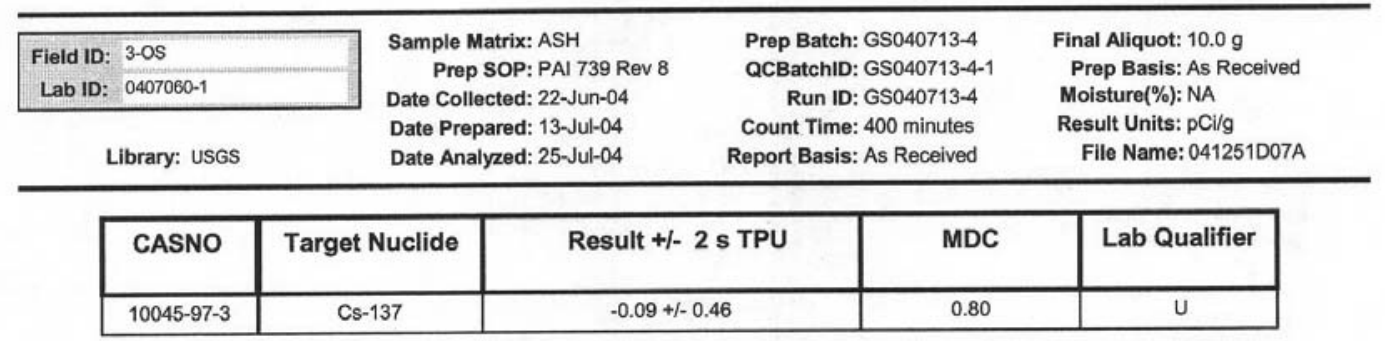

Comments:

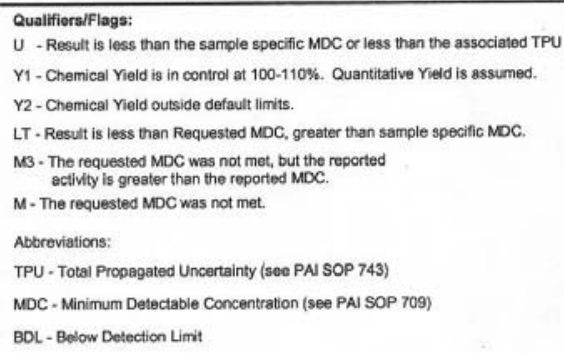

Data Package ID: GSA0407060-1

Date Printed: Tuesday, August 24, 2004 


\section{Gamma Spectroscopy Results \\ PAI 713 Rev 8}

Sample Results

Lab Name: Paragon Analytics

Work Order Number: 0407060

Client Name: ESH2O_LANL

ClientProject ID: AREA G OS Vegetation 7H02 C34A 3 A00 0009

\begin{tabular}{|c|c|c|c|c|c|c|c|}
\hline \multirow{2}{*}{$\begin{array}{l}\text { Field ID: } \\
\text { Lab ID: }\end{array}$} & \multicolumn{2}{|l|}{$7 \mathrm{~A}-\mathrm{OS}$} & \multirow{2}{*}{\multicolumn{2}{|c|}{$\begin{array}{l}\text { Sample Matrix: ASH } \\
\text { Prep SOP: PAI } 739 \text { Rev } 8 \\
\text { Date Collected: } 22 \text {-Jun-04 }\end{array}$}} & \multirow{2}{*}{\multicolumn{2}{|c|}{$\begin{array}{l}\text { Prep Batch: GS040713-3 } \\
\text { QCBatchID: GS040713-3-1 } \\
\text { Run ID: GS040713-3A }\end{array}$}} & \multirow{2}{*}{$\begin{array}{l}\text { Final Aliquot: } 7.10 \mathrm{~g} \\
\text { Prep Basis: As Receivec } \\
\text { Moisture(\%): NA }\end{array}$} \\
\hline & \multicolumn{2}{|l|}{$0407060-2$} & & & & & \\
\hline & jbrary: USGS & & $\begin{array}{l}\text { Date Prep } \\
\text { Date Anal }\end{array}$ & $\begin{array}{l}\text { 3-Jul-04 } \\
\text { 4-Jul-04 }\end{array}$ & $\begin{array}{r}\text { Coun } \\
\text { Report }\end{array}$ & $\begin{array}{l}\text { hutes } \\
\text { eived }\end{array}$ & $\begin{array}{l}\text { Result Units: pCi/g } \\
\text { File Name: } 041336 \mathrm{D} 03\end{array}$ \\
\hline & CASNO & Target $\mathrm{A}$ & Vuclide & Result +1 & s TPU & MDC & Lab Qualifier \\
\hline & $10045-97-3$ & Cs-1 & & $0.24+1$ & & 0.99 & $U$ \\
\hline
\end{tabular}

Comments:

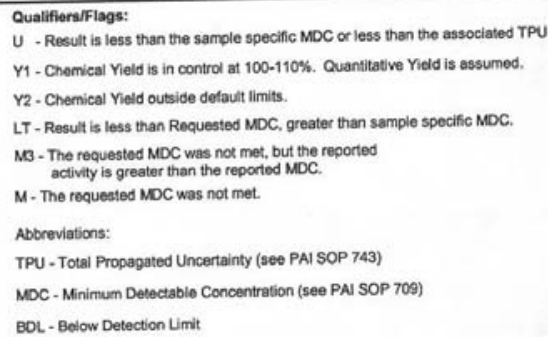




\section{Gamma Spectroscopy Results}

\section{PAI 713 Rev 8}

Sample Results

Lab Name: Paragon Analytics

Work Order Number: 0407060

Client Name: ESH20_LANL

ClientProject ID: AREA G OS Vegetation 7H02 C34A 3A00 0009

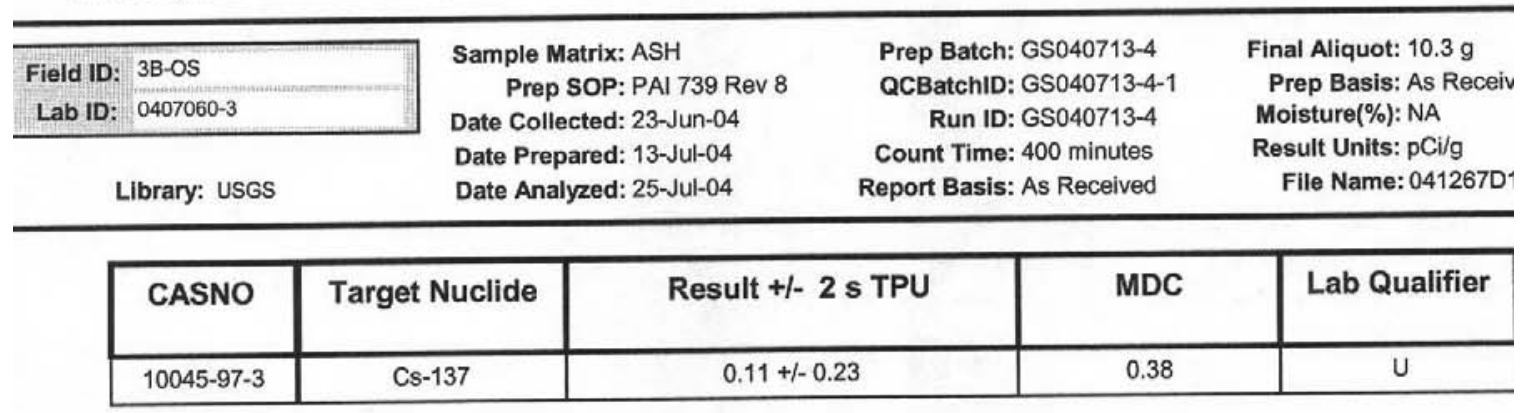

\section{Comments:}

Qualiflers/Flags:

$U$-Result is less than the sample specific MDC or less than the assoclated TPU

$\mathrm{Y} 1$ - Chemical Yield is in control at 100-110\%. Quantitative Yield is assumed.

Y2 - Chemical Yield outside default limits.

LT - Result is less than Requested MDC, greater than sample specific MOC.

M3 - The requested MDC was not met, but the reported activity is greater than the reported MDC.

$M-$ The requested MDC was not met.

Abbreviations:

TPU - Total Propagated Uncertainty (see PAI SOP 743)

MDC - Minimum Detectable Concentration (see PAI SOP 709)

BDL - Below Detection Limit

Data Package ID: GSA0407060-1

SQ-Spectral quality prevents accurate quantitation.

SI - Nuclide identification and/or quantitation is tentative.

TI- Nuclide identification is tentative.

R - Nuclide has exceeded 8 halfives.

G - Sample density differs by more than $15 \%$ of LCS density. 


\section{Gamma Spectroscopy Results}

\section{PAl 713 Rev 8}

\section{Sample Results}

Lab Name: Paragon Analytics

Work Order Number: 0407060

Client Name: ESH20_LANL

ClientProject ID: AREA G OS Vegetation 7H02 C34A 3A00 0009

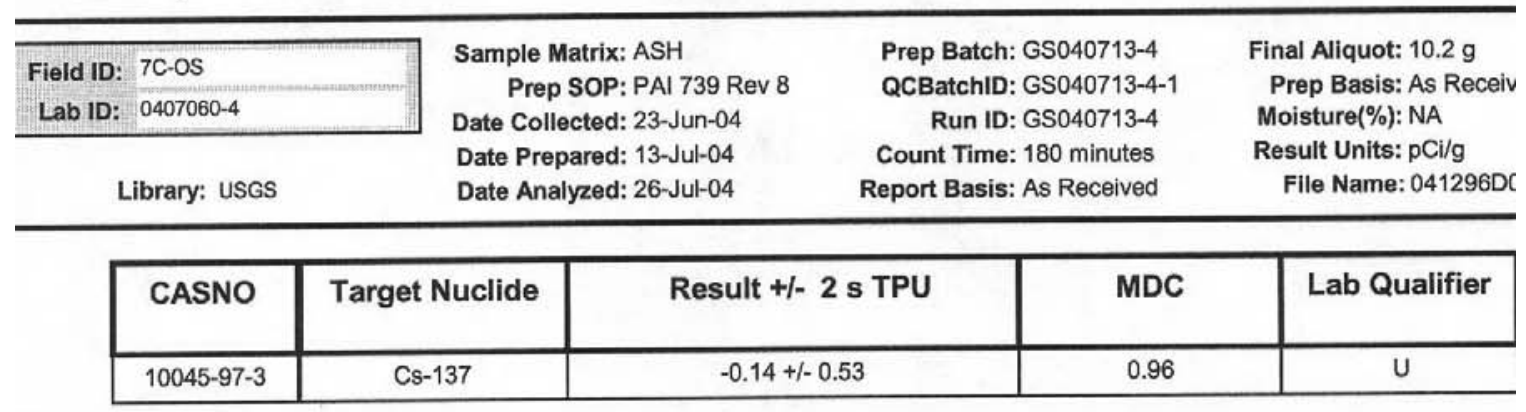

Comments:

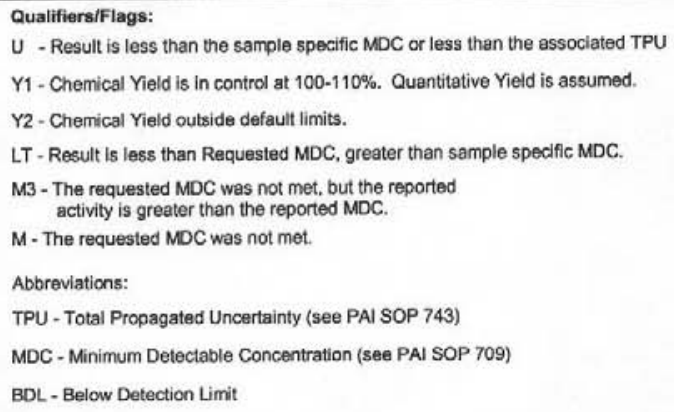

Data Package ID: GSA0407060-1 


\section{Gamma Spectroscopy Results \\ PAI 713 Rev 8}

Sample Results

Lab Name: Paragon Analytics

Work Order Number: 0407060

Client Name: ESH20_LANL

ClientProject ID: AREA G OS Vegetation 7H02 C34A 3A00 0009

\begin{tabular}{|c|c|c|c|c|c|}
\hline Field ID: $4-0 S$ & \multirow{2}{*}{\multicolumn{2}{|c|}{$\begin{array}{l}\text { Sample Matrix: ASH } \\
\text { Prep SOP: PAI } 739 \text { Rev } 8 \\
\text { Date Collected: } 23-J u n-04 \\
\text { Date Prepared: } 13-J u l-04 \\
\text { Date Analyzed: } 26-J u l-04\end{array}$}} & \multirow{2}{*}{\multicolumn{2}{|c|}{$\begin{array}{l}\text { Prep Batch: GS040713-4 } \\
\text { QCBatchID: GS040713-4-1 } \\
\text { Run ID: GS040713-4 } \\
\text { Count Time: } 180 \text { minutes } \\
\text { Report Basis: As Received }\end{array}$}} & \multirow{2}{*}{$\begin{array}{l}\text { Final Aliquot: } 10.0 \mathrm{~g} \\
\text { Prep Basis: As Received } \\
\text { Moisture(\%): NA } \\
\text { Result Units: pCi/g } \\
\text { File Name: 041286D08A }\end{array}$} \\
\hline Library: USGS & & & & & \\
\hline CASNO & Target Nuclide & \multicolumn{2}{|c|}{ Result + $/-2 \mathrm{~s}$ TPU } & MDC & Lab Qualifier \\
\hline $10045-97-3$ & Cs-137 & $0.10+1$ & & 0.95 & U \\
\hline
\end{tabular}

Comments:

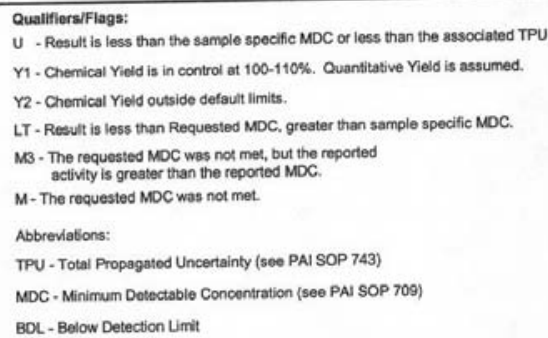

U - Result is less than the sample specific MDC of less than the associated TPU

Y1. Chemical Yield is in control ot 100-110\%. Quantitative Yield is assumed.

Y2-Chemical Yieid outside detaut limits.

LT - Result is less than Requested MDC. greater than sample specific MOC.

M3 - The requested MOC was not met, but the roported

$M$ - The requested MDC was not met.

Abbreviabions:

TPU - Total Propagatod Uncertainty (soe PAI SOP 743)

MDC - Minimum Dotectable Concontration (see PAI SOP 709)

BOL - Below Detection Limit

SQ - Spectral qualily prevents accurate quantitation.

Data Package ID: GSA0407060-1

Date Printed: Tuesday, August 24, 2004 


\section{Gamma Spectroscopy Results \\ PAI 713 Rev 8 \\ Sample Results}

Lab Name: Paragon Analytics

Work Order Number: 0407060

Client Name: ESH20_LANL

ClientProject ID: AREA G OS Vegetation 7H02 C34A 3A00 0009

\begin{tabular}{l} 
Field ID: 6B-OS \\
Lab ID: $0407060-6$ \\
\hline
\end{tabular}

Sample Matrix: ASH

Prep SOP: PAI 739 Rev 8

Date Collected: 23-Jun-04

Date Prepared: 13-Jul-04

Library: USGS
Prep Batch: GS040713-4

QCBatchID: GS040713-4-1

Run ID: GS040713-4

Count Time: 180 minutes

Report Basis: As Received
Final Aliquot: $10.2 \mathrm{~g}$

Prep Basis: As Receiv

Moisture(\%): NA

Result Units: $\mathrm{pCi} / \mathrm{g}$

File Name: 041269D1

\begin{tabular}{|c|c|c|c|c|}
\hline CASNO & Target Nuclide & Result +1- 2 s TPU & MDC & Lab Qualifier \\
\hline $10045-97-3$ & Cs-137 & $0.03+1-0.38$ & 0.64 & $U$ \\
\hline
\end{tabular}

\section{Comments:}

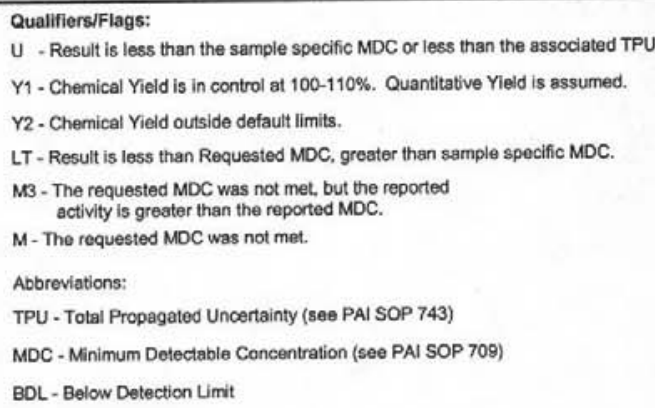

U - Result is less than the sample specific MDC or less than the associated TPU

$\mathrm{Y} 1$ - Chemical Yield is in control at $100-110 \%$. Quantitative Yield is assumed.

Y2 - Chemical Yield outside default limits.

LT - Result is less than Requested MDC, greater than sample specific MDC.

M3 - The requested MDC was not met, but the reported activity is greater than the reported MDC.

M - The requested MDC was not met.

Abbreviations:

TPU - Total Propagated Uncertainty (see PAI SOP 743)

MDC - Minimum Detectable Concentration (see PAI SOP 709)

BDL - Below Detection Limit

$S Q$-Spectral quality prevents accurate quantitation.

Data Package ID: GSA0407060-1 


\section{Gamma Spectroscopy Results}

PAI 713 Rev 8

Sample Results

Lab Name: Paragon Analytics

Work Order Number: 0407060

Client Name: ESH20_LANL

ClientProject ID: AREA G OS Vegetation 7H02 C34A 3A00 0009

\begin{tabular}{|c|c|c|}
\hline Field ID: $1-O S$ & Sample Matrix: ASH & Prep Batch: GS040713-4 \\
\hline Lab ID: $0407060-7$ & Date Collected: 23 Jun-04 & Run ID: GS040713-4 \\
\hline Library: USGS & $\begin{array}{l}\text { Date Prepared: } 13-J u l-04 \\
\text { Date Analyzed: } 27-J u l-04\end{array}$ & $\begin{array}{l}\text { Count Time: } 105 \text { minutes } \\
\text { Report Basis: As Received }\end{array}$ \\
\hline
\end{tabular}

Final Aliquot: $10.1 \mathrm{~g}$

Prep Basis: As Received

Moisture(\%): NA

Result Units: pCi/g

Report Basis: As Received

File Name: 041273D10A

\begin{tabular}{|c|c|c|c|c|}
\hline CASNO & Target Nuclide & Result +/- 2 s TPU & MDC & Lab Qualifier \\
\hline $10045-97-3$ & Cs-137 & $-0.02+/-0.48$ & 0.83 & $U$ \\
\hline
\end{tabular}

\section{Comments:}

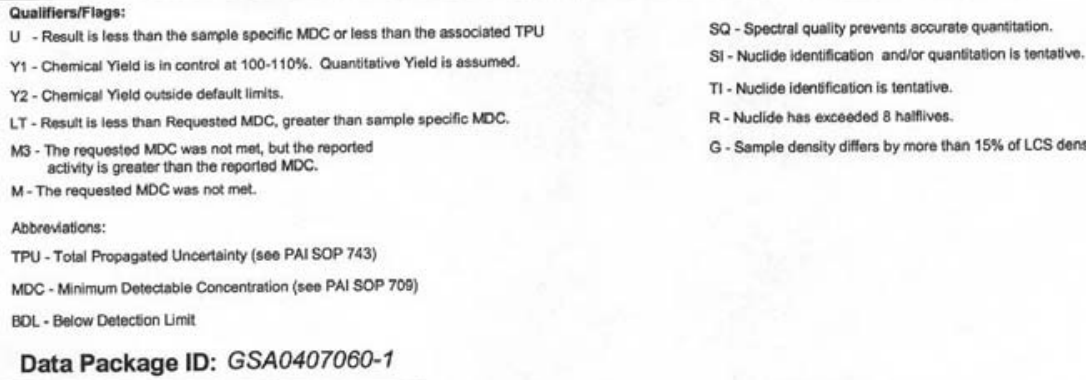

Date Printed: Tuesday, August 24, 2004
Page 7 of 11

000025 


\section{Gamma Spectroscopy Results \\ PAI 713 Rev 8}

Sample Results

Lab Name: Paragon Analytics

Work Order Number: 0407060

Client Name: ESH20_LANL

ClientProject ID: AREA G OS Vegetation 7H02 C34A 3A00 0009

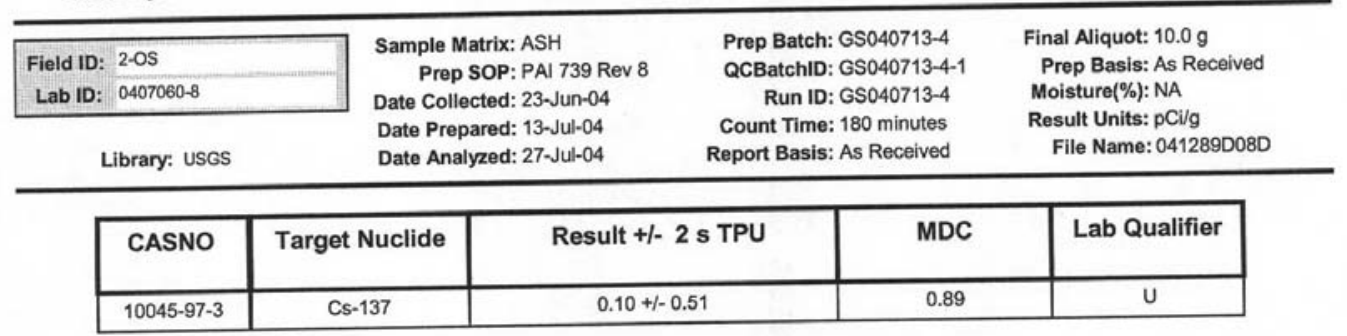

Qualifiers/Flags:

$U$ - Result is less than the sample specific MDC of less than the associated TPU

$\mathrm{Y} 1$ - Chemical Yield is in control at 100-110\%. Quantitative Yield is assumed.

Y2-Chemical Yiold outside defaut limits.

LT - Result is less than Requested MDC. greater than sample specific MOC.

MS - The requested MOC was not met, but the reported

$M$ - The requestod MDC was not met.

Abbreviations:

TPU - Total Propagatod Uncertainty (see PAI SOP 743)

MDC - Minimum Detectable Concentration (see PAI SOP 709)

BOL. Below Detection Umet

Data Package ID: GSA0407060-1

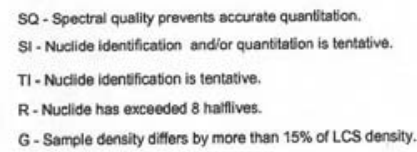

Date Printed: Tuesday, August 24, 2004
Paragon Analytics

LIMS Version: $5.054 \mathrm{~A}$
Page 8 of 11

ถกกอรล 


\section{Gamma Spectroscopy Results}

\section{PAI 713 Rev 8}

\section{Sample Results}

Lab Name: Paragon Analytics

Work Order Number: 0407060

Client Name: ESH20_LANL

ClientProject ID: AREA G OS Vegetation 7H02 C34A 3 A00 0009

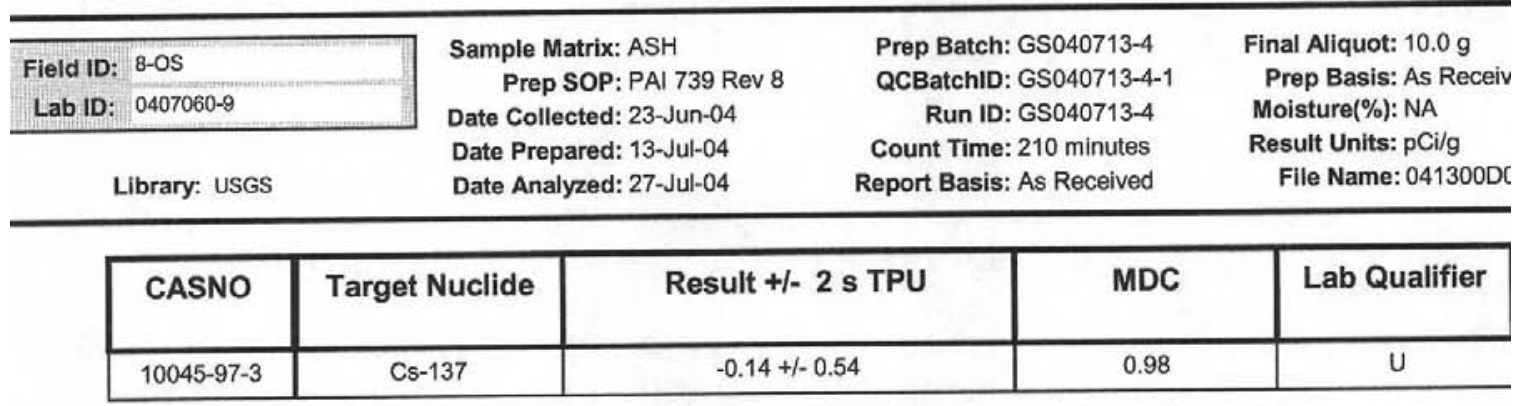

\section{Comments:}

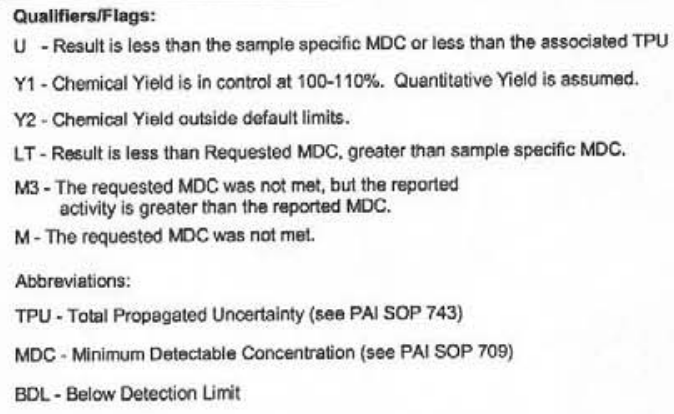

$U$ - Result is less than the sample specific MDC or less than the associated TPU

Y1 - Chemical Yield is in control at 100-110\%. Quantitative Yield is assumed.

Y2 - Chemical Yield outside default limits.

LT - Result is less than Requested MDC, greater than sample specific MDC.

M3 - The requested MDC was not met, but the reported activity is greater than the reported MDC.

$M$ - The requested MDC was not met.

Abbreviations:

TPU - Total Propagated Uncertainty (see PAI SOP 743)

MDC - Minimum Detectable Concentration (see PAI SOP 709)

BDL - Below Detection Limit

Data Package ID: GSA0407060-1 


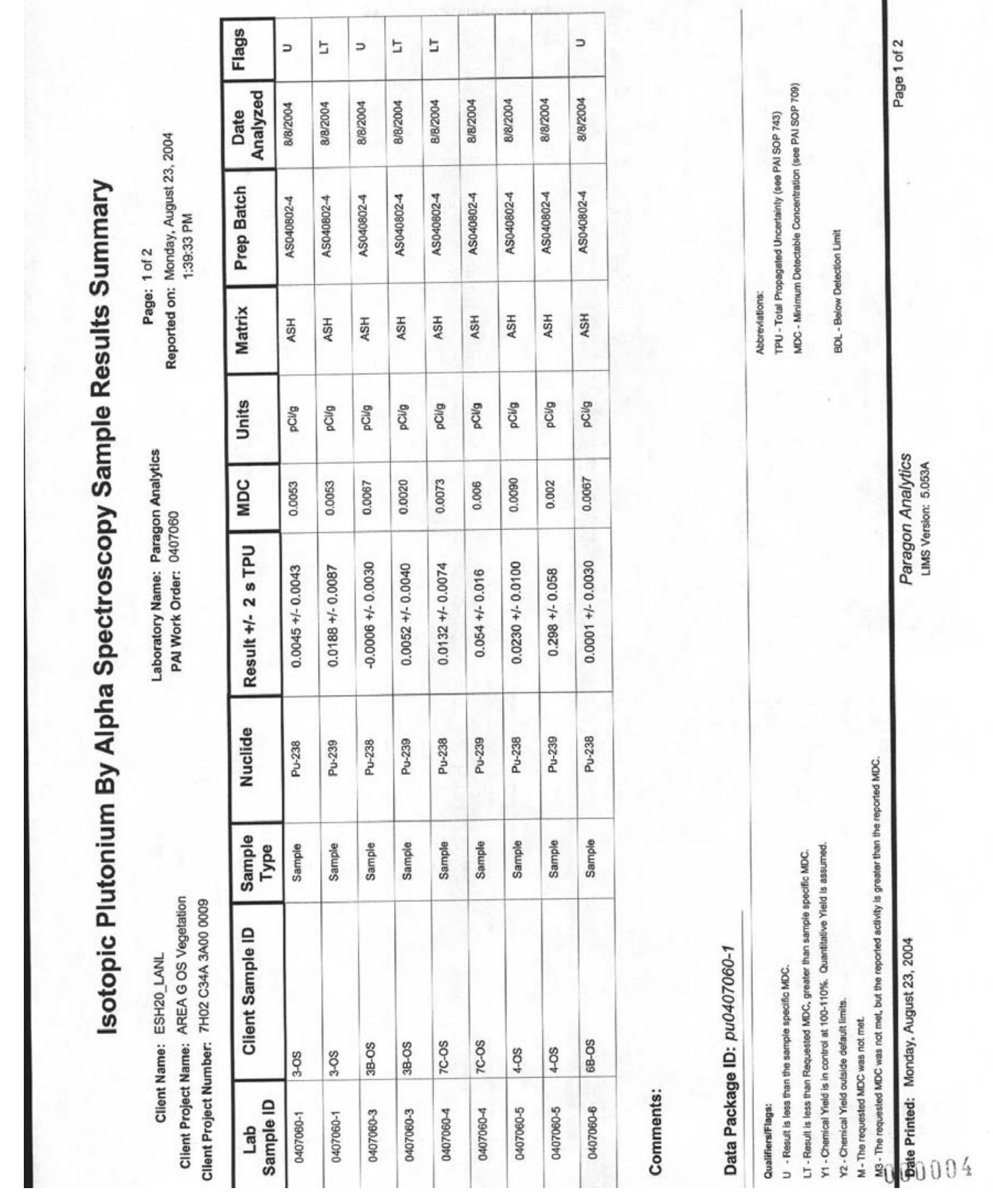



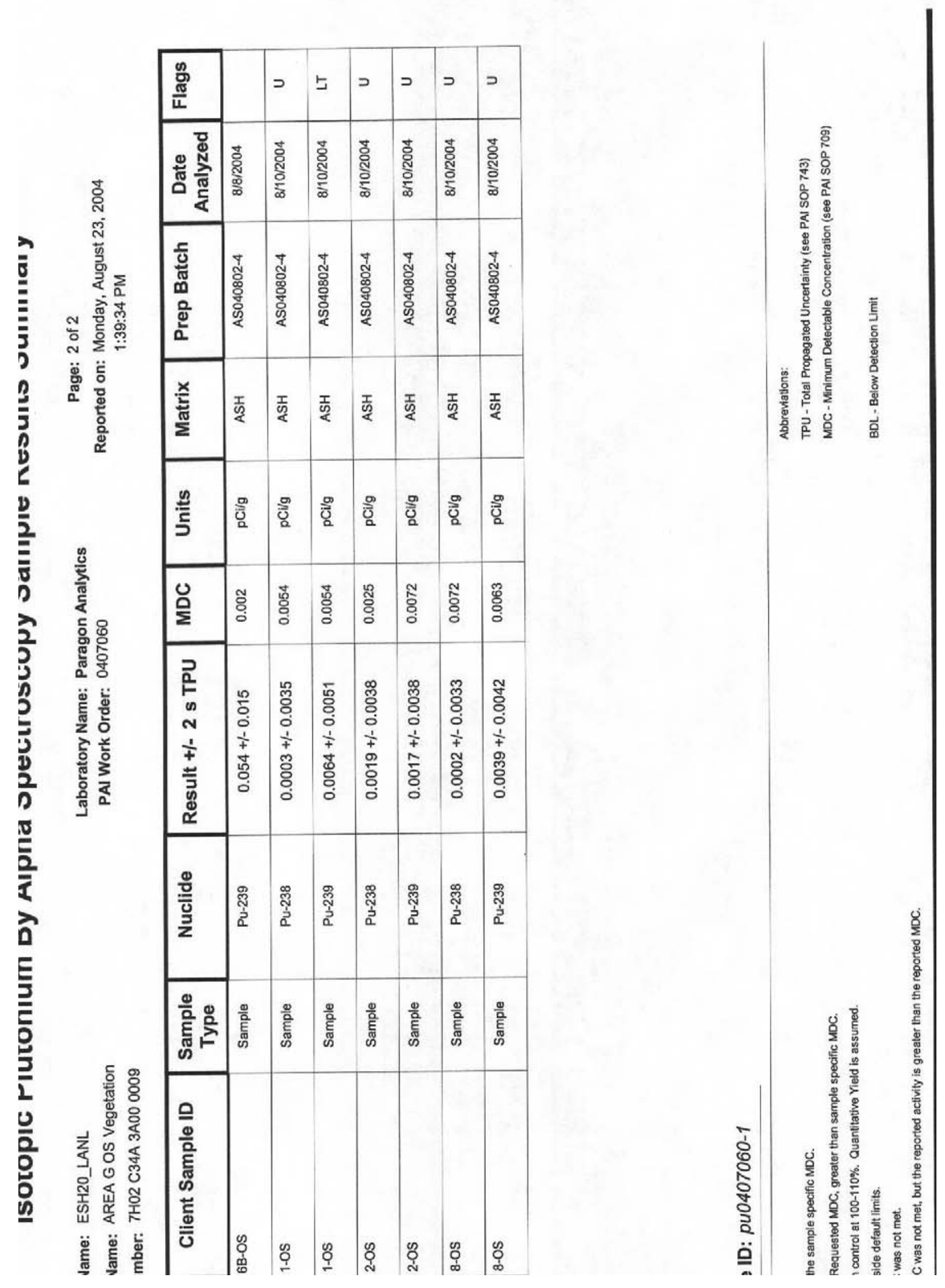

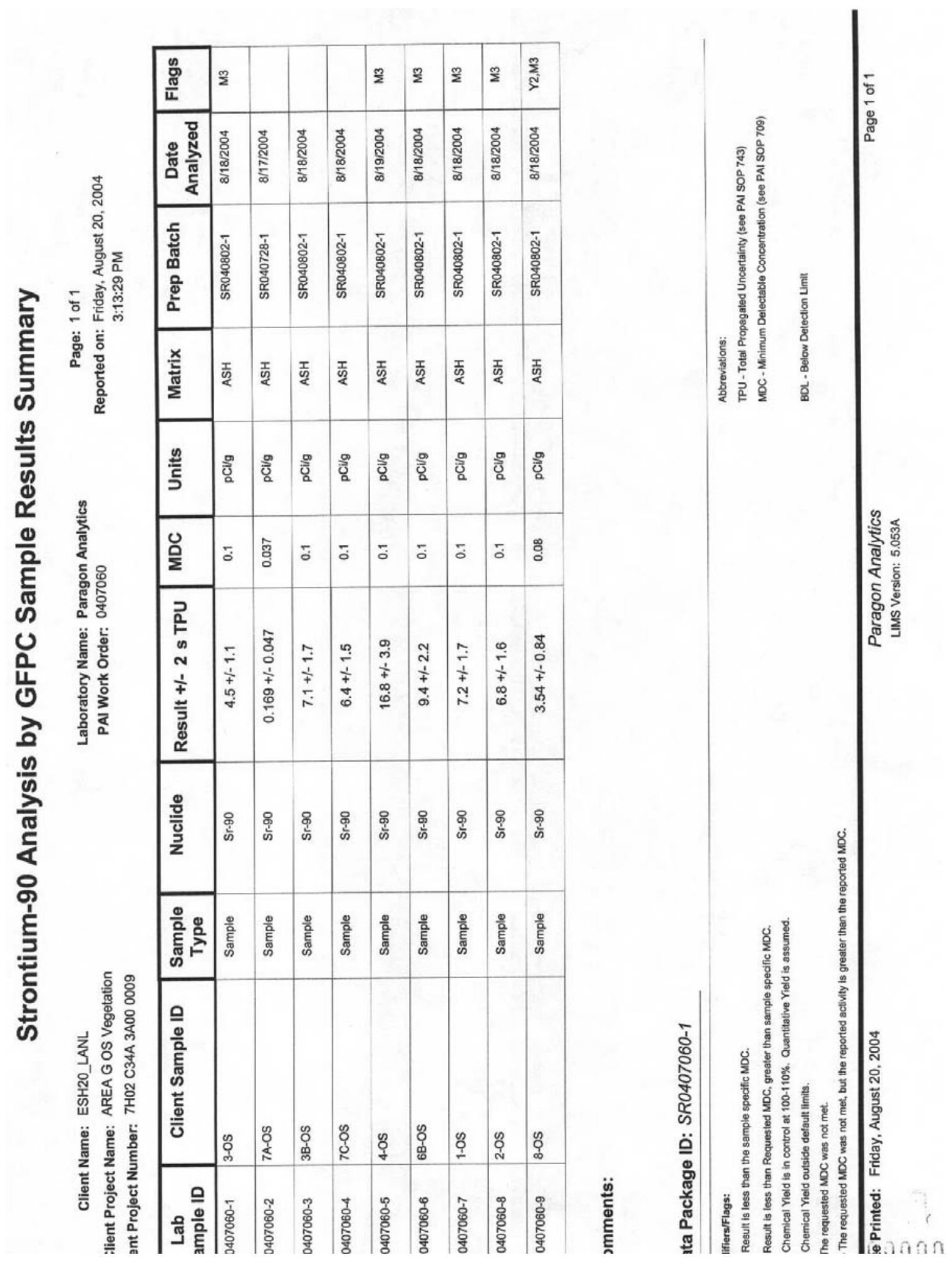

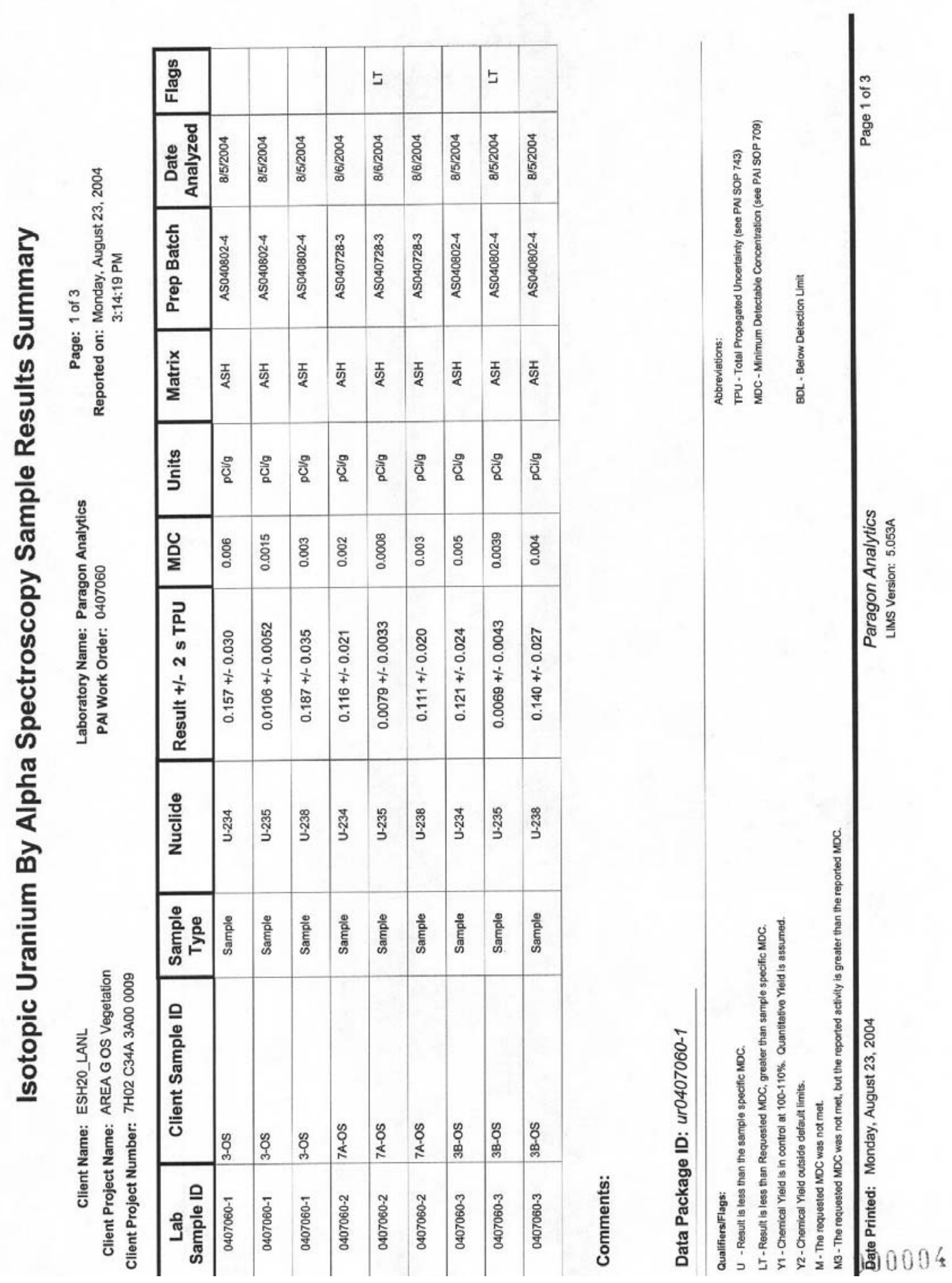

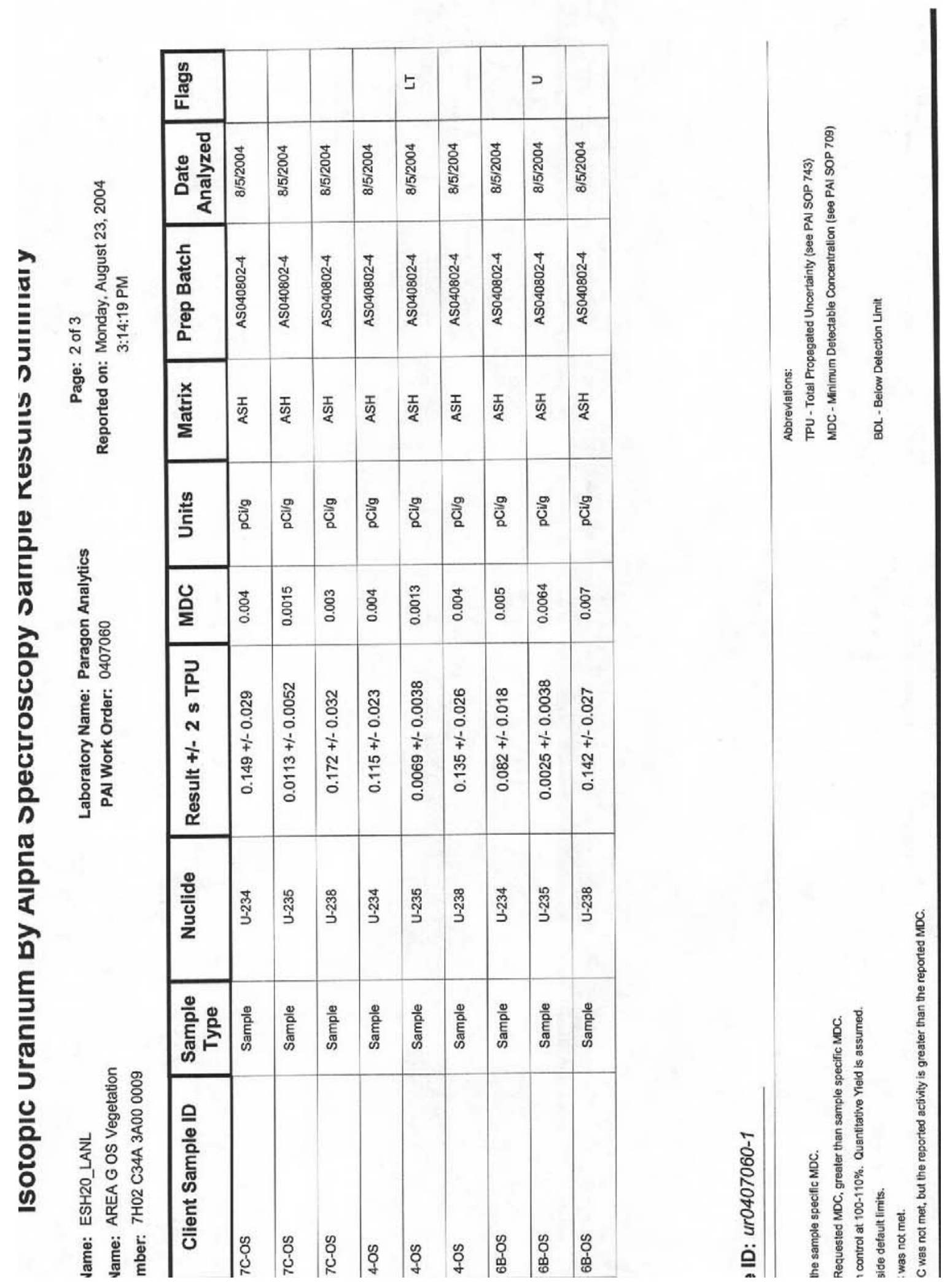

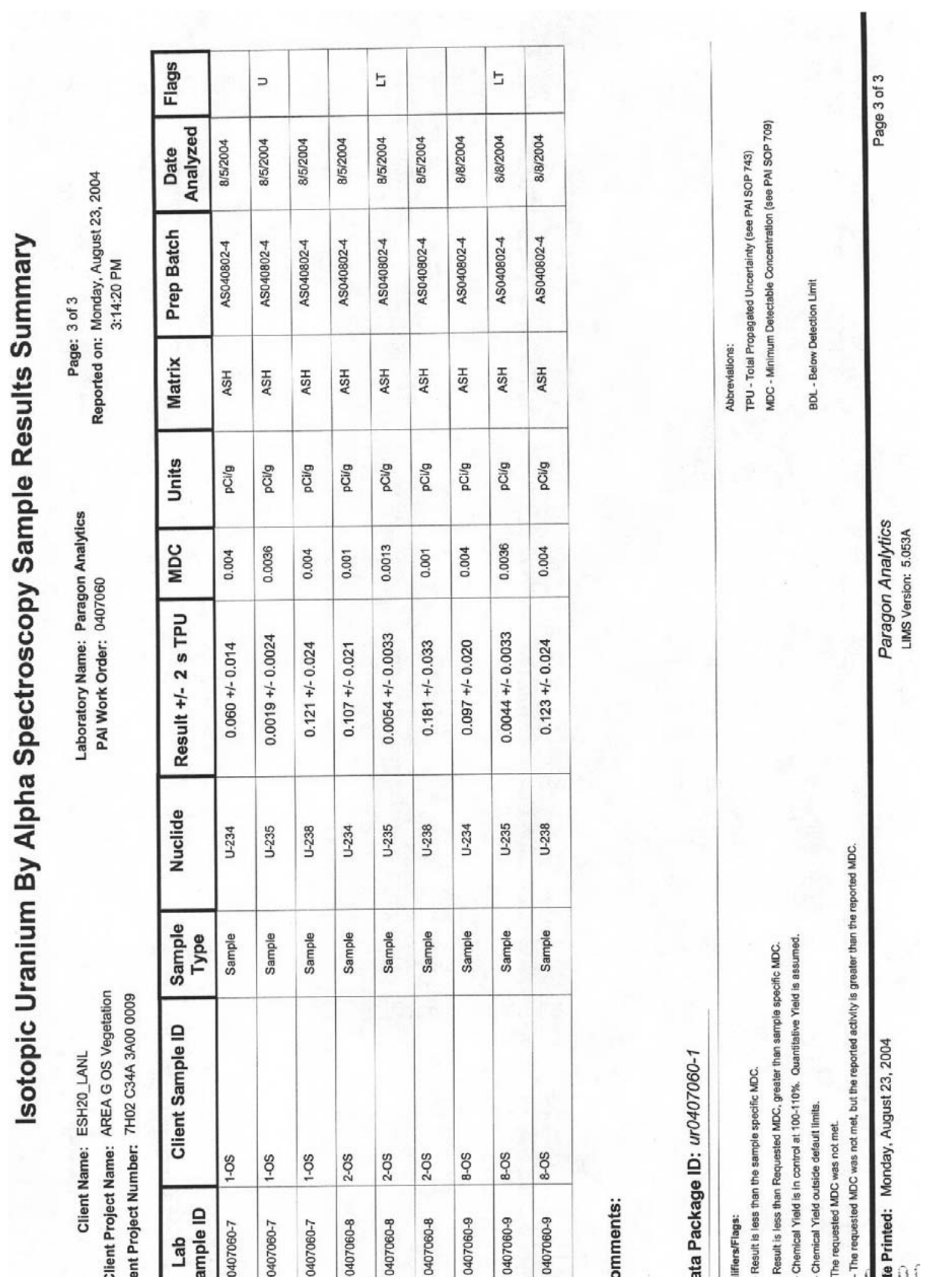


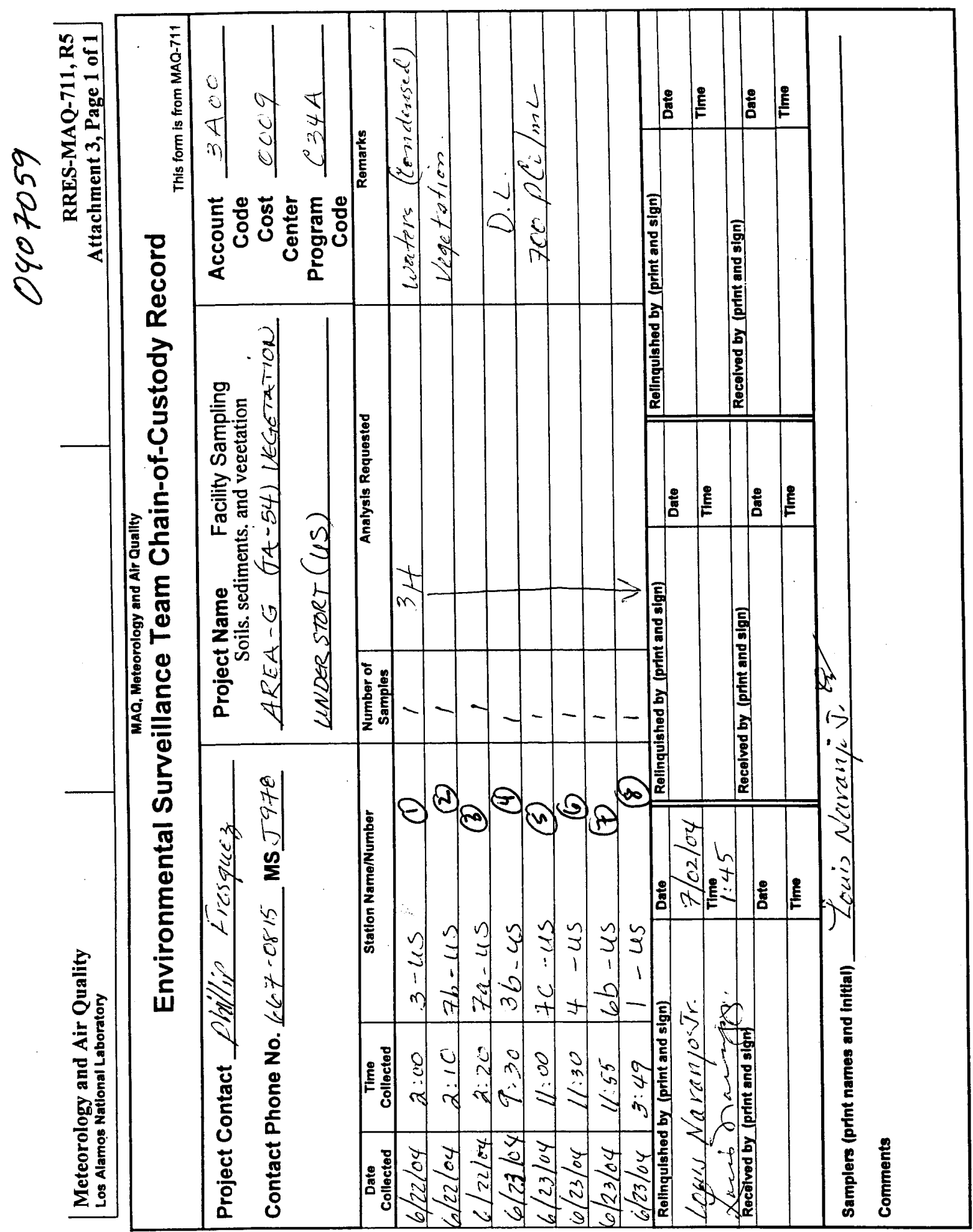




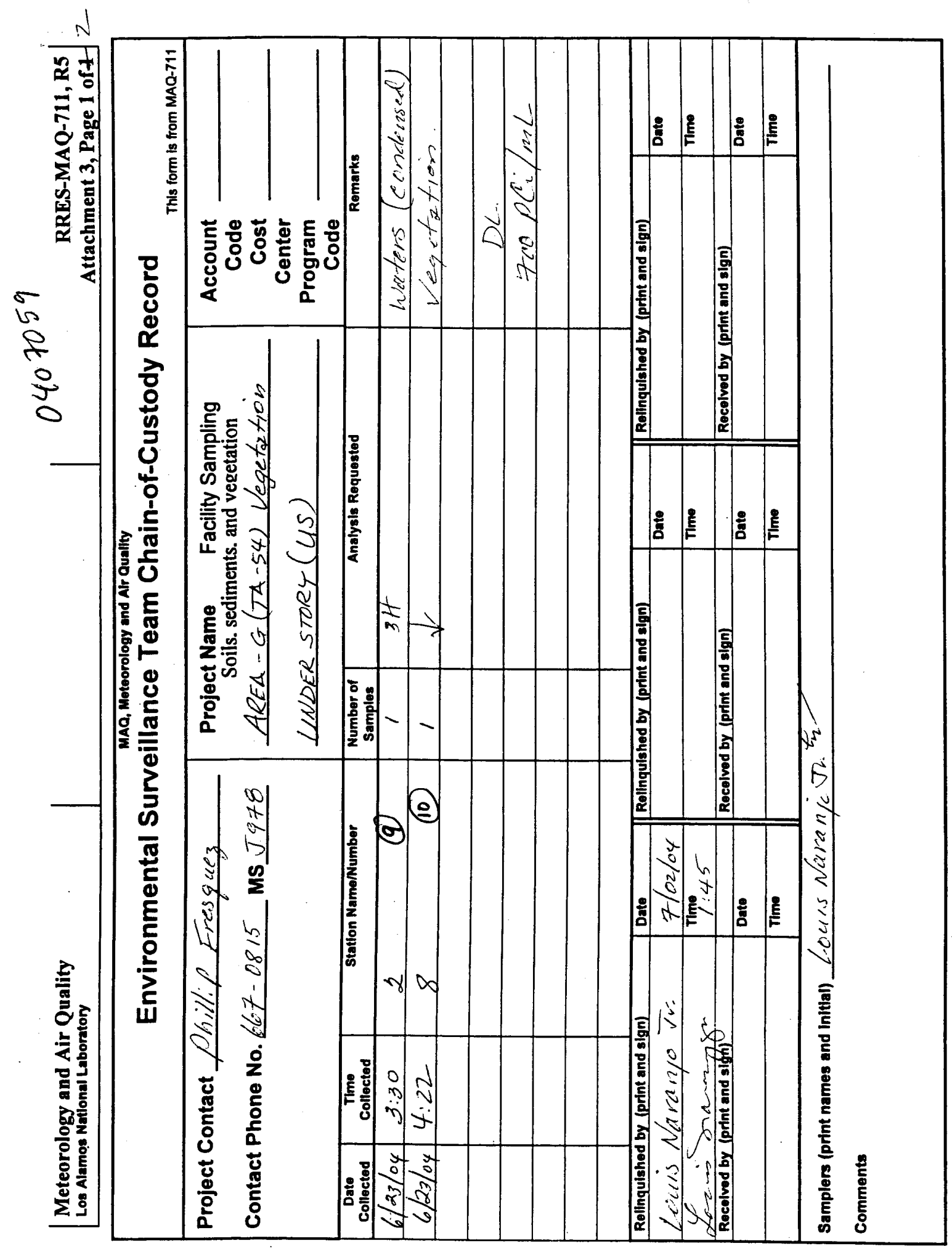



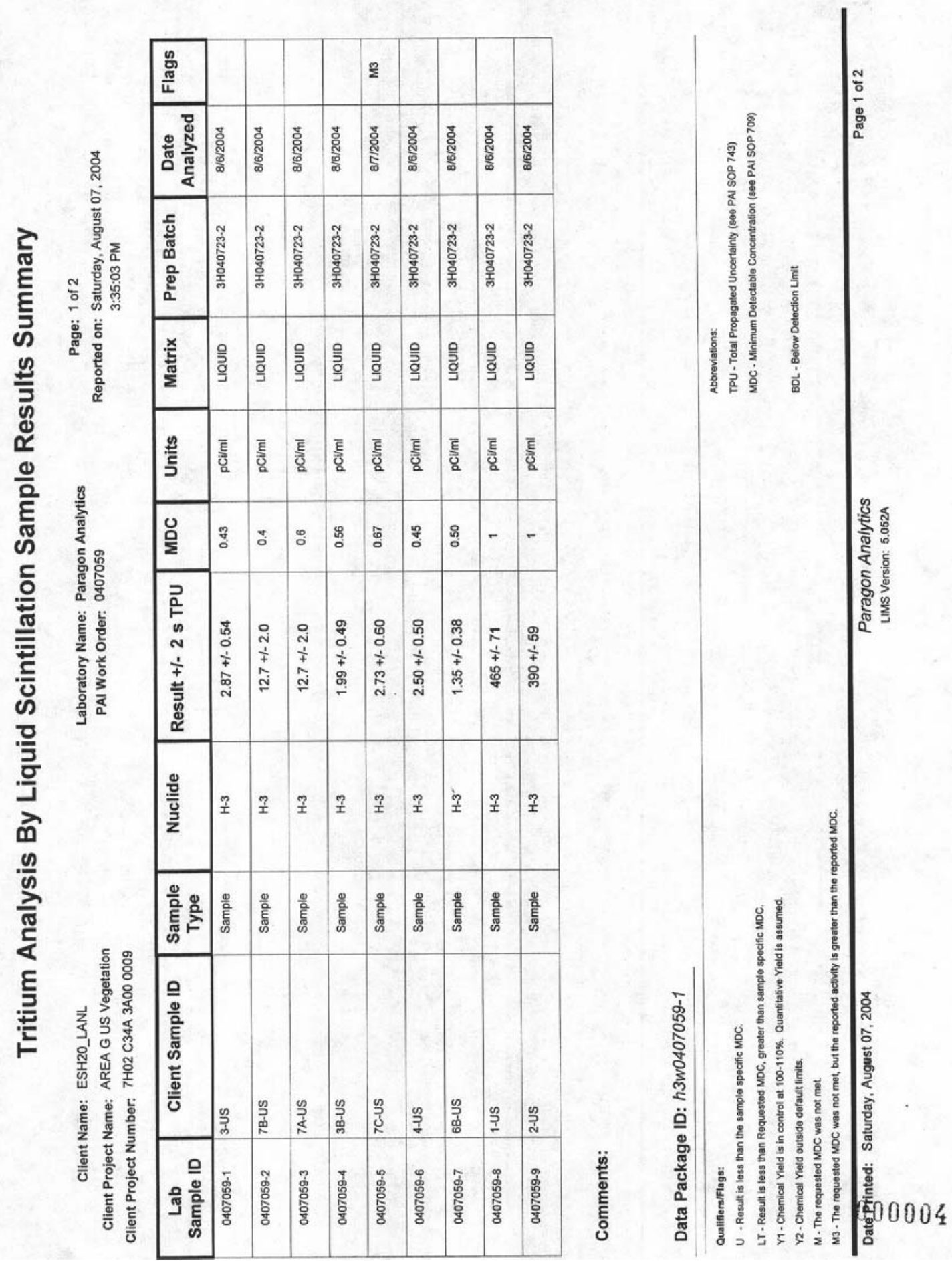

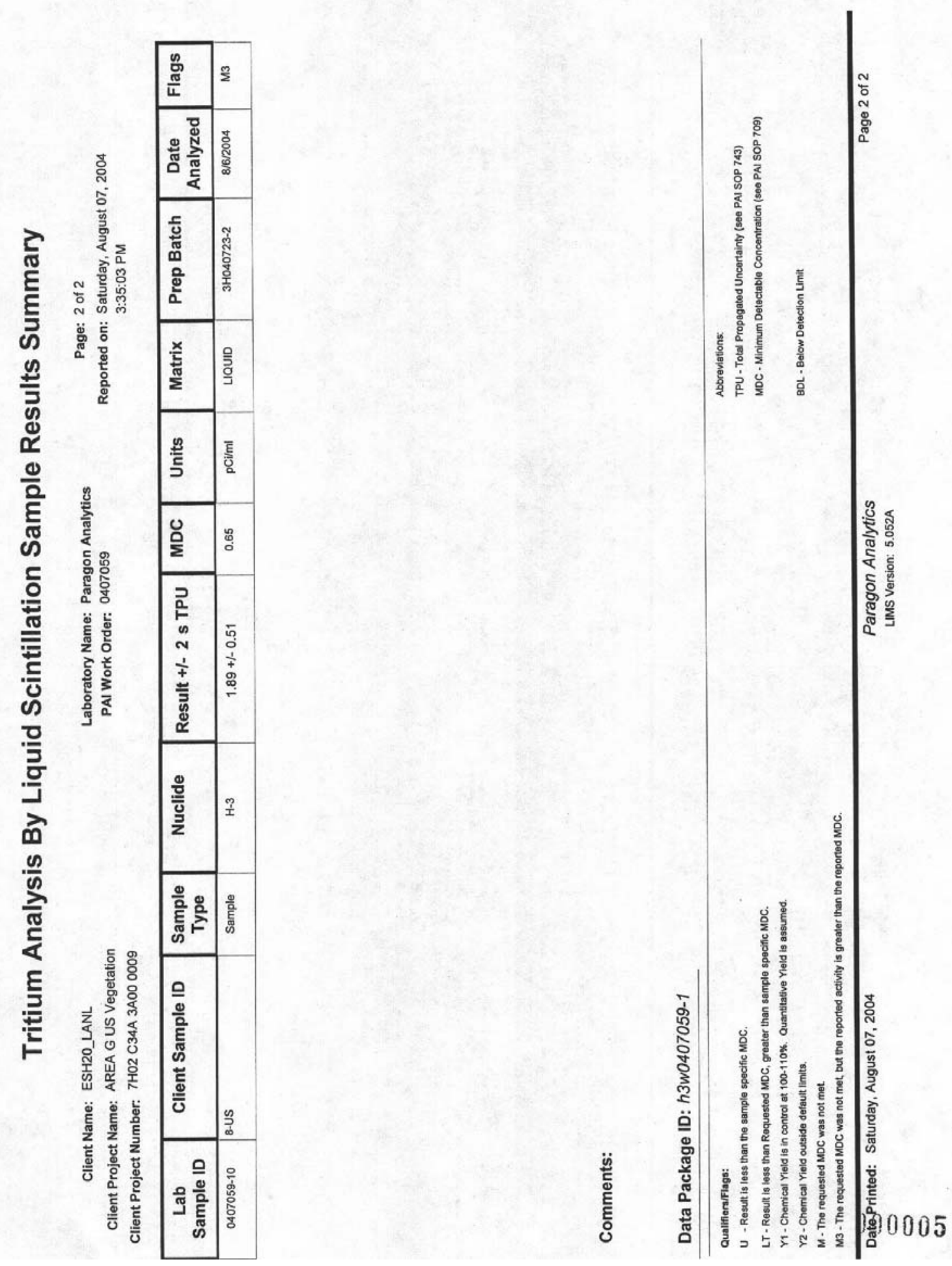


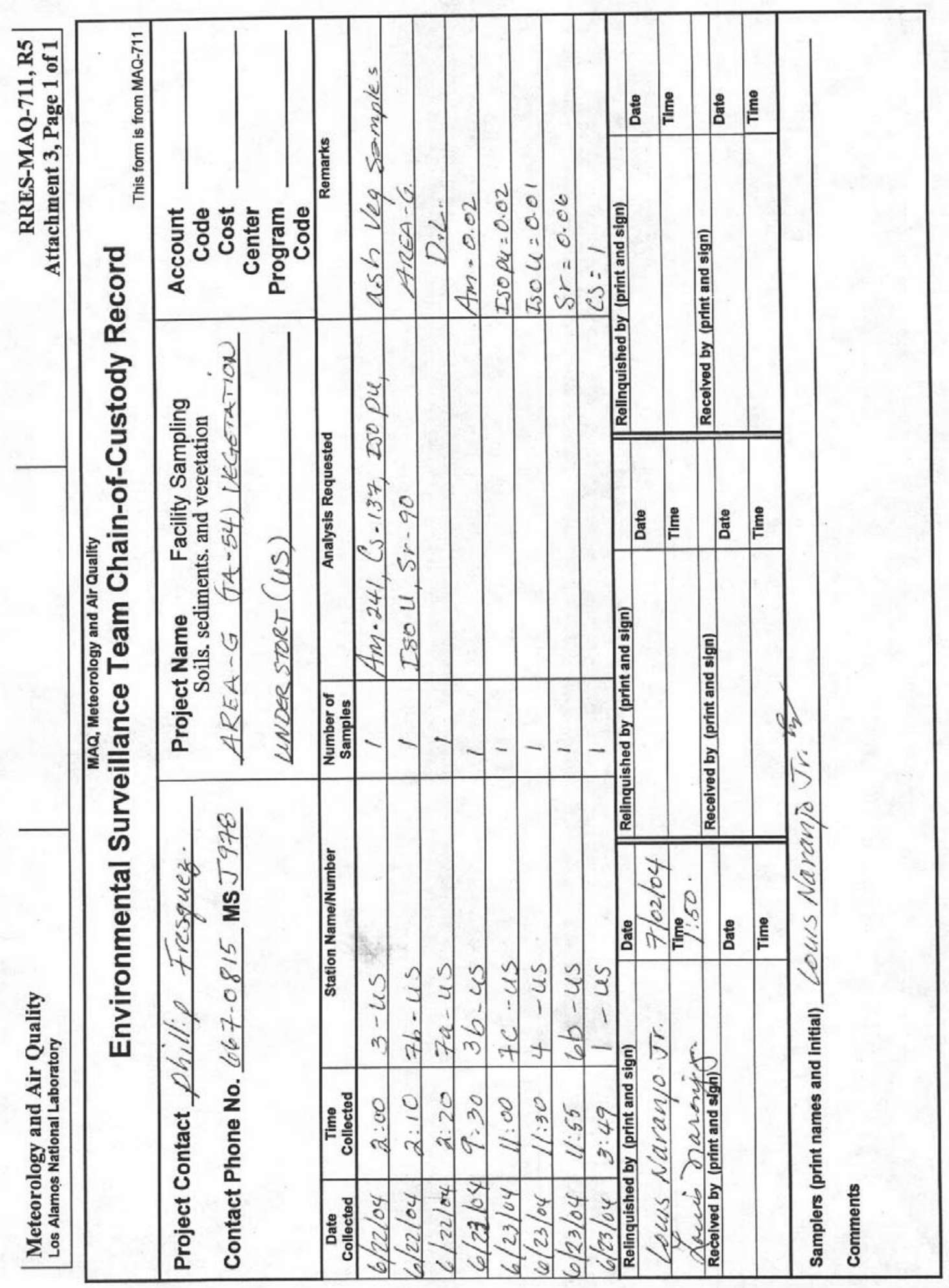




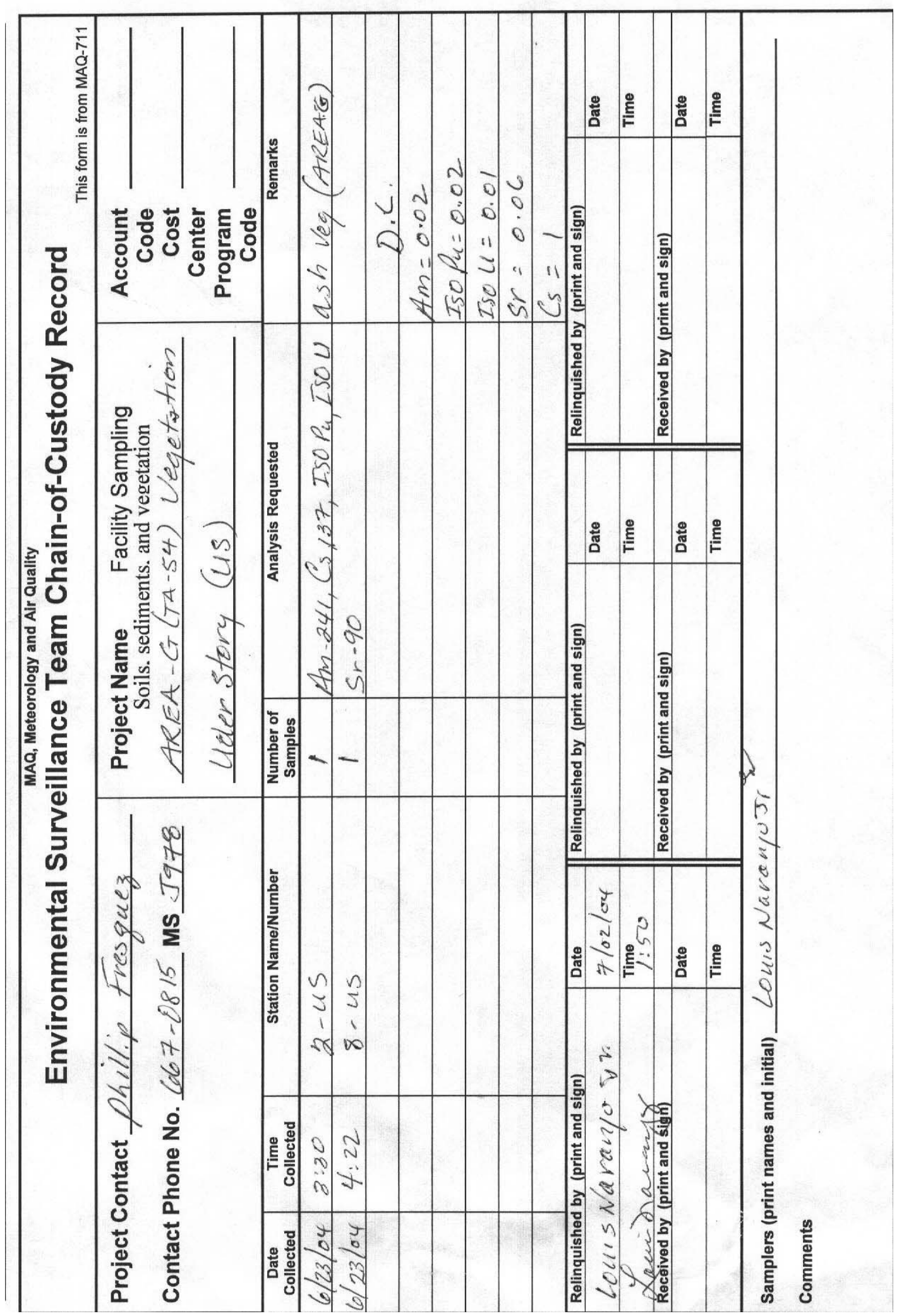




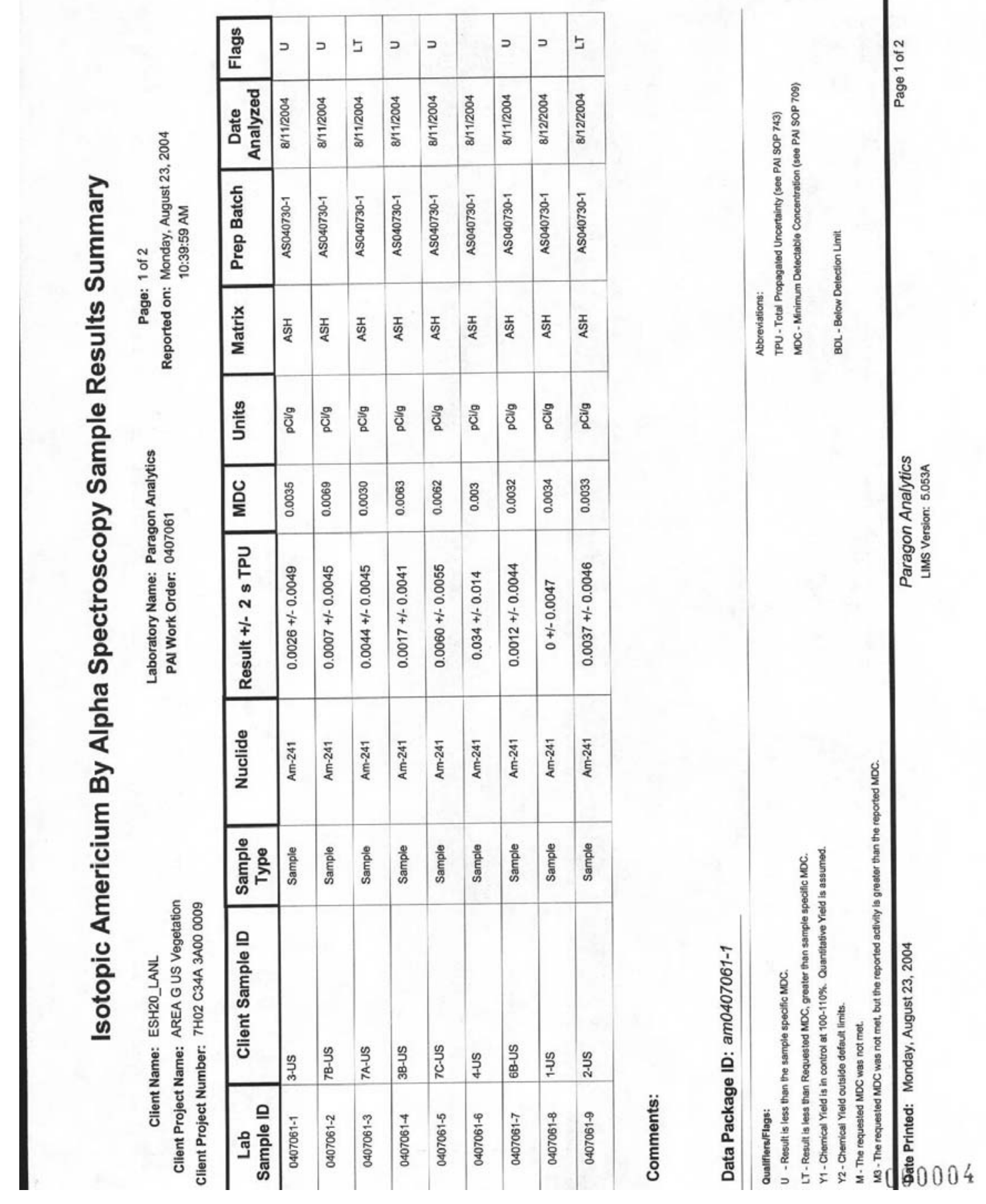



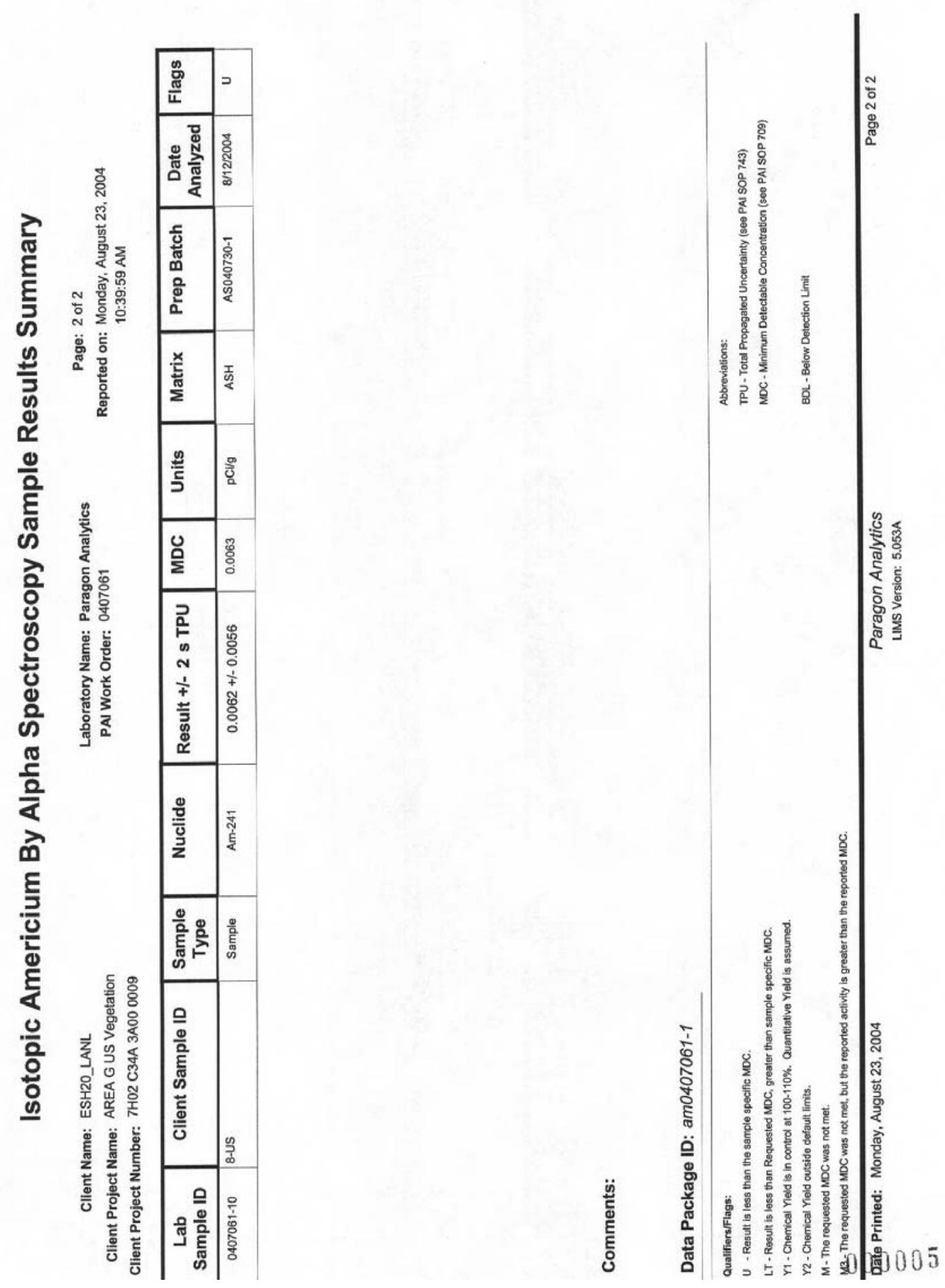


\title{
Gamma Spectroscopy Results
}

\author{
PAI 713 Rev 8 \\ Sample Results
}

Lab Name: Paragon Analytics

Work Order Number: 0407061

Client Name: ESH20_LANL

ClientProject ID: AREA G US Vegetation 7H02 C34A 3 A00 0009

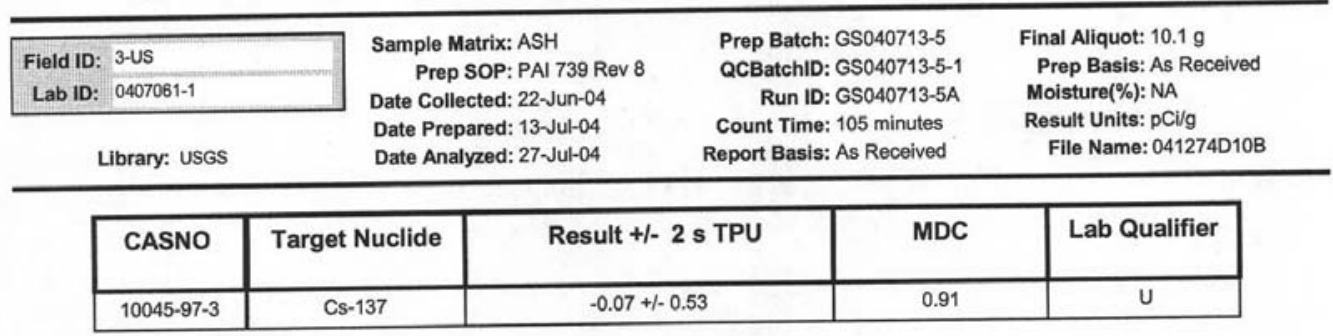

\section{Comments:}

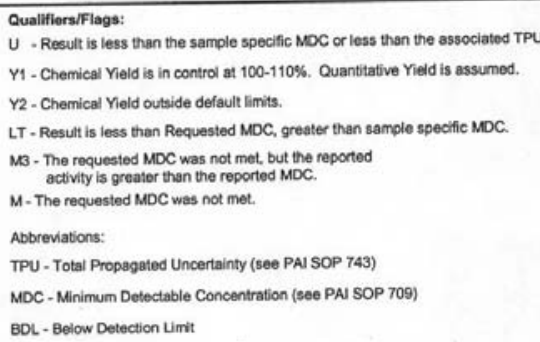

Data Package ID: GSA0407061-1 


\section{Gamma Spectroscopy Results \\ PAI 713 Rev 8}

\section{Sample Results}

Lab Name: Paragon Analytics

Work Order Number: 0407061

Client Name: ESH20_LANL

ClientProject ID: AREA G US Vegetation 7H02 C34A 3A00 0009

\begin{tabular}{|c|c|c|c|}
\hline Field ID: 7B-US & Sample Matrix: ASH & Prep Batch: GS040713-5 & Final Aliquot: $10.5 \mathrm{~g}$ \\
\hline Lab ID: $0407061-2$ & $\begin{array}{l}\text { Prep SOP: PAI } 739 \text { Rev } 8 \\
\text { Date Collected: } 22-J u n-04\end{array}$ & $\begin{array}{l}\text { QCBatchID: GS040713-5-1 } \\
\text { Run ID: GS040713-5A }\end{array}$ & $\begin{array}{l}\text { Prep Basis: As Received } \\
\text { Moisture(\%): NA }\end{array}$ \\
\hline & Date Prepared: $13-J u l-04$ & Count Time: 180 minutes & Result Units: pCi/g \\
\hline Library: USGS & Date Analyzed: 27-Jul-04 & Report Basis: As Received & File Name: 041291D08B \\
\hline
\end{tabular}

\begin{tabular}{|c|c|c|c|c|}
\hline CASNO & Target Nuclide & Result +/- 2 s TPU & MDC & Lab Qualifier \\
\hline $10045-97-3$ & Cs-137 & $0.01+/-0.54$ & 0.95 & $U$ \\
\hline
\end{tabular}

Comments:

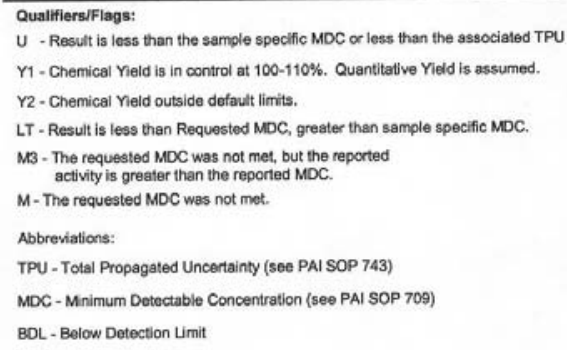




\section{Gamma Spectroscopy Results}

\section{PAI 713 Rev 8}

Sample Results

Lab Name: Paragon Analytics

Work Order Number: 0407061

Client Name: ESH2O_LANL

ClientProject ID: AREA G US Vegetation 7H02 C34A 3 A00 0009

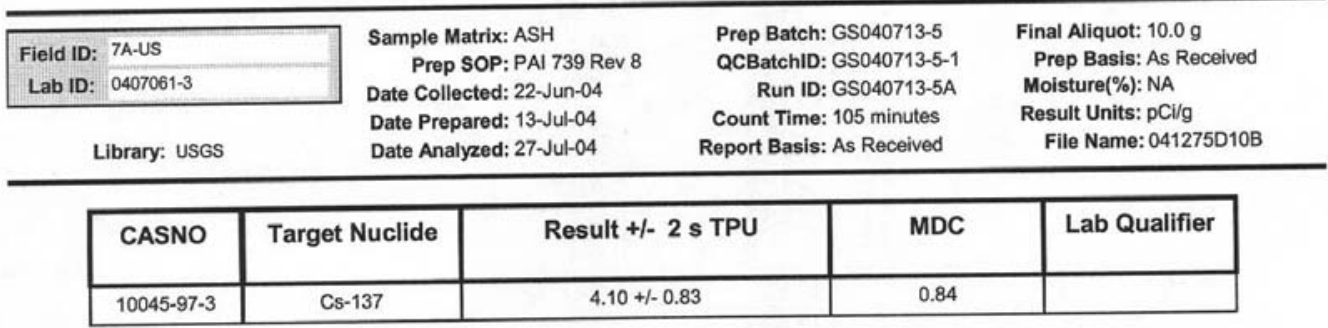

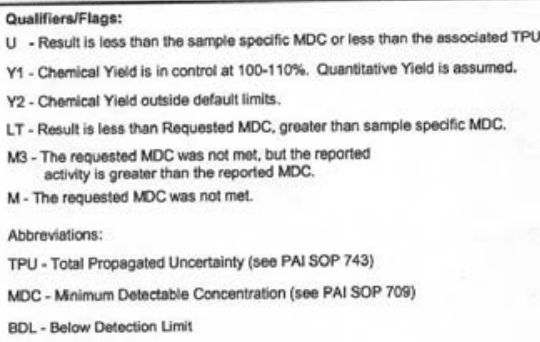

Data Package ID: GSA0407061-1 


\section{Gamma Spectroscopy Results \\ PAI 713 Rev 8}

Sample Results

Lab Name: Paragon Analytics

Work Order Number: 0407061

Client Name: ESH2O_LANL

ClientProject ID: AREA G US Vegetation 7H02 C34A 3A00 0009

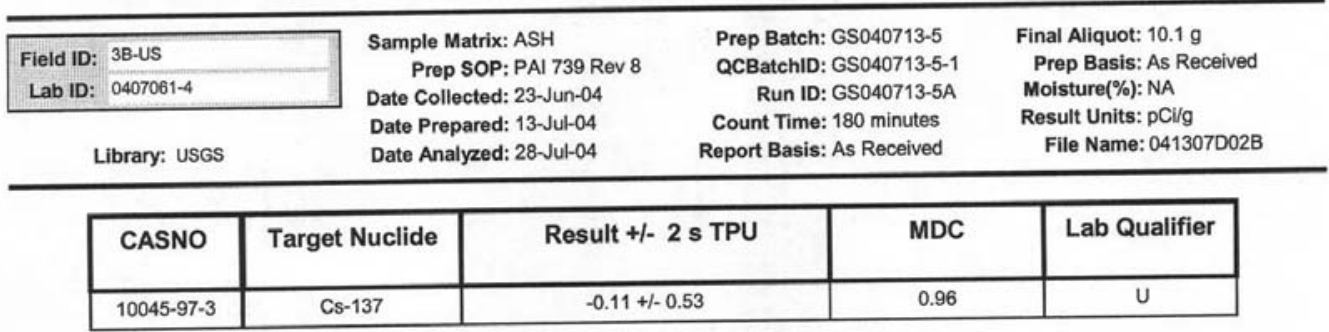

Comments:

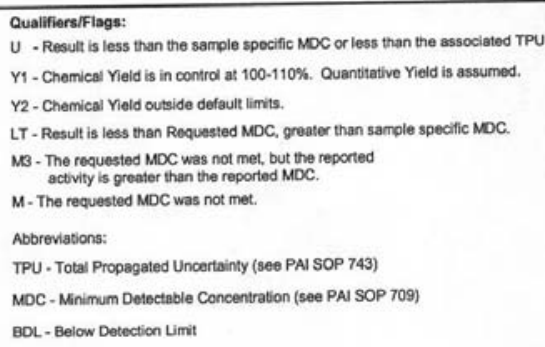

$U$ - Result is less than the sample spocific MOC or less than the associated TPU

Y1 - Chemical Yield is in control at 100-110\%. Quantitative Yield is assumed.

Y2 - Chemical Vield outside defautt limits.

LT - Result is less than Requested MDC, greater than sample specific MOC.

MB - The requested MDC was not met, but the reported

activity is greater than the reported MDC.

$M$ - The requested MDC was not met.

Abbreviasons:

TPU - Total Propagated Uncertainty (see PAI SOP 743)

MDC - Mnimum Detectable Concentration (see PAI SOP 709)

BDL - Below Detection Lim

Data Package ID: GSA0407061-1 


\section{Gamma Spectroscopy Results}

PAI 713 Rev 8

Sample Results

Lab Name: Paragon Analytics

Work Order Number: 0407061

Client Name: ESH20_LANL

ClientProject ID: AREA G US Vegetation 7H02 C34A 3 A00 0009

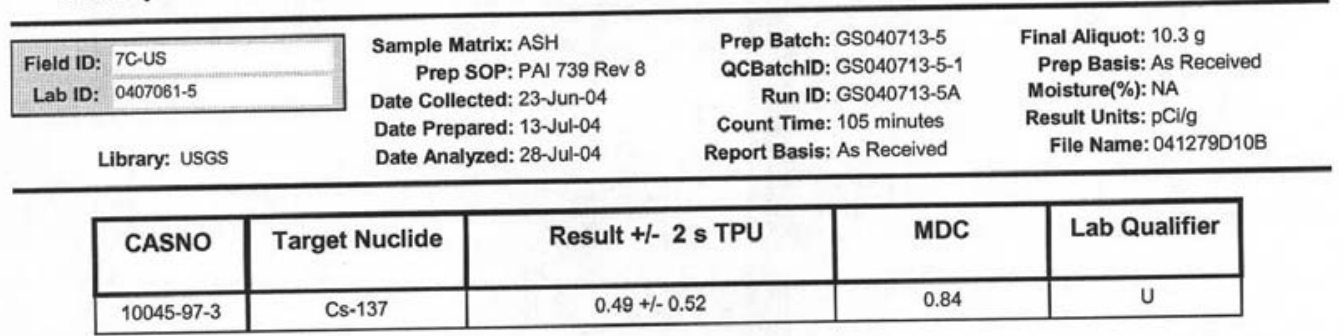

Qualifiers/Flags:

$U$-Result is less than the sample specific MOC or less than the associated TPU

Y1 - Chemical Yield is in control at $100-110 \%$. Quantiative Yield is assumed.

Y2-Chemical Yield outside default limits.

LT - Result is less than Requested MOC, greater than sample specific MDC.

MB - The requested MOC was not met, but the reported
activity is grester than the reported MOC.

M- The requested MOC was not met.

Abbreviation:

TPU - Total Propagated Uncentainty (see PAI SOP 743)

MDC - Mnimum Detectable Concentration (see PAI SOP 709)

BOL - Below Detection Limit

Data Package ID: GSA0407061-1
Paragon Analytics

LIMS Version: $5.054 \mathrm{~A}$
SQ - Spectral quality prevents accurate quantitation.
S1 - Nuclide identification andlior quantitation is tentabve.
$\pi$ - Nuclide identification is tentative.
$R$ - Nucilde has exceeded 8 halfives.
G - Sample density differs by more than $15 \%$ of LCS density.

Date Printed: Tuesday, August 24, 2004

Page 5 of 10

000013 


\section{Gamma Spectroscopy Results}

PAI 713 Rev 8

Sample Results

Lab Name: Paragon Analytics

Work Order Number: 0407061

Client Name: ESH2O_LANL

ClientProject ID: AREA G US Vegetation 7H02 C34A 3A00 0009

\begin{tabular}{|c|c|c|c|c|c|}
\hline \multirow{2}{*}{$\begin{aligned} & \text { Field ID: } \text { 4-US } \\
& \text { Lab ID: } 0407061-6 \\
&\end{aligned}$} & \multirow{3}{*}{\multicolumn{2}{|c|}{$\begin{array}{l}\text { Sample Matrix: ASH } \\
\text { Prep SOP: PAI } 739 \text { Rev } 8 \\
\text { Date Collected: } 23-J u n-04 \\
\text { Date Prepared: } 13-J u l-04 \\
\text { Date Analyzed: } 28-J u l-04\end{array}$}} & \multirow{3}{*}{\multicolumn{2}{|c|}{$\begin{array}{l}\text { Prep Batch: GS040713-5 } \\
\text { QCBatchID: GS040713-5-1 } \\
\text { Run ID: GS040713-5A } \\
\text { Count Time: } 180 \text { minutes } \\
\text { Report Basis: As Received }\end{array}$}} & \multirow{3}{*}{$\begin{array}{l}\text { Final Aliquot: } 10.1 \mathrm{~g} \\
\text { Prep Basis: As Received } \\
\text { Moisture(\%): NA } \\
\text { Result Units: pCi/g } \\
\text { File Name: } 041310 \mathrm{D02A}\end{array}$} \\
\hline & & & & & \\
\hline Library: USGS & & & & & \\
\hline CASNO & Target Nuclide & \multicolumn{2}{|c|}{ Result +/- 2 s TPU } & MDC & Lab Qualifier \\
\hline $10045-97-3$ & Cs-137 & $0.25+1$ & & 1.00 & $u$ \\
\hline
\end{tabular}

Comments:

\section{Qualifiers/Flags:}

U - Result is less then the sample specific MDC or less than the associatod TPU

$\mathrm{Y} 1$. Chemical Yield is in control at $100-110 \%$, Quantitative Yield is assumed.

Y2 - Chemical Yield outside detault limits.

LT - Result is less than Requested MDC, greater than sample specific MDC.

M3 - The requested MDC was not met, but the reported

$M$ - The requested MDC was not met.

Abbreviabons:

TPU - Total Propagated Uncertainty (see PAI SOP 743)

MDC - Minimum Detoctable Concontration (see PAI SOP 709)

BOL-Below Detection Limi

Data Package ID: GSA0407061-1

Date Printed: Tuesday, August 24, 2004

Paragon Analytics

LIMS Version: $5.054 \mathrm{~A}$
SQ - Soectral quality prevents accurate quantitation.

S1 - Nuclide identification and/or quantitation is tentafive.

Ti- Nuclide idenbfication is tentative.

R- Nuclide has exceeded 8 hasflives.

G- Sample density differs by more than $15 \%$ of LCS density.
Page 6 of 10

000014 


\section{Gamma Spectroscopy Results}

PAI 713 Rev 8

Sample Results

Lab Name: Paragon Analytics

Work Order Number: 0407061

Client Name: ESH20_LANL

ClientProject ID: AREA G US Vegetation 7H02 C34A 3 A00 0009

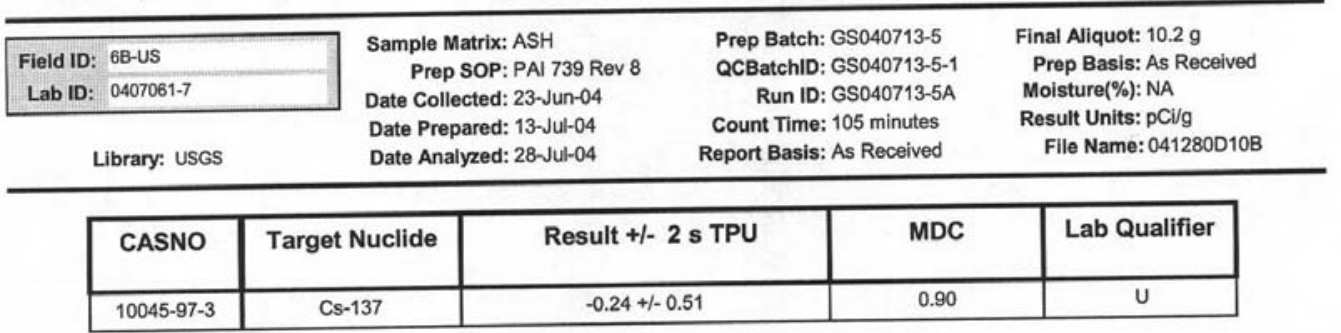

Qualifiers/Flags:

U - Rosult is less than the sample specific MDC or less than the associated TPU

Y1 - Chemical Yield is in control at 100-110\%. Quantitafve Yield is assumed.

Y2 - Chemical Yield outside detault linits.

LT - Result is less than Requested MDC, greater than sample specific MDC.

Ma - The requested MDC was not met, but the reported
activity is greater than the reported $M D C$.

- The requested MDC was not met.

Abbreviations:

TPU - Total Propagated Uncertainty (see PAI SOP 743)

MOC - Mnimum Detectable Concentration (see PAI SOP 709)

BDL - Below Detection Limt

Data Package ID: GSA0407061-1
SQ - Spectral quality prevents accurate quantitatilion.

S1 - Nuclide identfication andior quantitation is tentasve.

TI- Nuclide identificaton is tentative.

R- Nuclide has exceeded 8 halfives.

G-Sample density difters by more than $15 \%$ of LCS density.
Date Printed: Tuesday, August 24, 2004

Paragon Analytics

LIMS Version: 5.054A
Page 7 of 10

000015 


\title{
Gamma Spectroscopy Results
}

\author{
PAl 713 Rev 8
}

Sample Results

Lab Name: Paragon Analytics

Work Order Number: 0407061

Client Name: ESH20_LANL.

ClientProject ID: AREA G US Vegetation 7H02 C34A 3 A00 0009

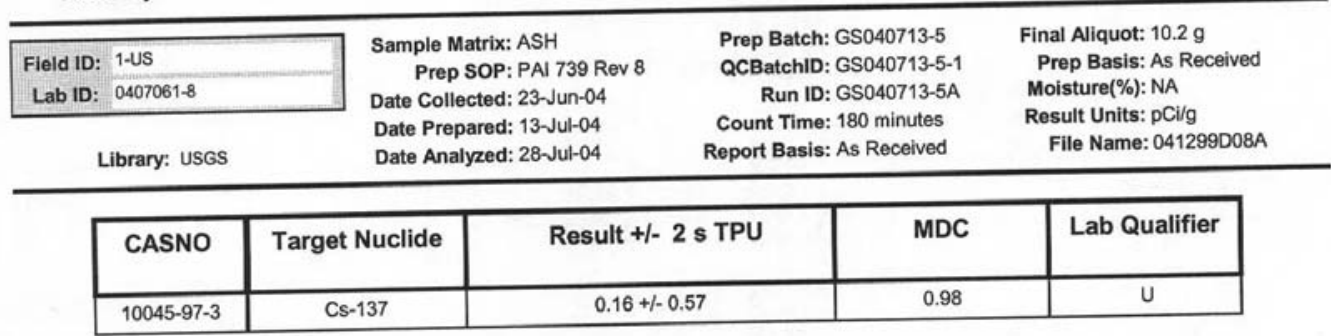

Qualifiers/Flags:

$U$ - Result is less than the sample specific MDC or less than the associated TPU

$Y 1$. Chemical Yield is in control at 100-110\%. Quantitative Yield is assumed.

Y2-Chemical Yield outside default limits.

LT - Result is less than Requested MDC, greater than sample specific MDC.

MB - The requested MDC was not met. but the reported
activity is greeter than the reported MDC.

$M$ - The requested MDC was not met

Abbreviations:

TPU - Total Propagated Uncertainty (see PAI SOP 743)

MOC-Mnimum Detectable Concentration (see PAI SOP 709)

BOL - Below Detection Uimit

Data Package ID: GSA0407061-1 


\section{Gamma Spectroscopy Results \\ PAI 713 Rev 8}

Sample Results

Lab Name: Paragon Analytics

Work Order Number: 0407061

Client Name: ESH2O_LANL

ClientProject ID: AREA G US Vegetation 7H02 C34A 3A00 0009

\begin{tabular}{|c|c|c|c|c|c|}
\hline Field ID: 2-US & \multirow{2}{*}{\multicolumn{2}{|c|}{$\begin{array}{l}\text { Sample Matrix: ASH } \\
\text { Prep SOP: PAI } 739 \text { Rev } 8 \\
\text { Date Collected: } 23-J u n-04 \\
\text { Date Prepared: } 13-J u l-04 \\
\text { Date Analyzed: } 28-J u l-04\end{array}$}} & \multirow{2}{*}{\multicolumn{2}{|c|}{$\begin{array}{l}\text { Prep Batch: GS040713-5 } \\
\text { QCBatchID: GS040713-5-1 } \\
\text { Run ID: GS040713-5A } \\
\text { Count Time: } 180 \text { minutes } \\
\text { Report Basis: As Received }\end{array}$}} & \multirow{2}{*}{$\begin{array}{l}\text { Final Aliquot: } 10.1 \mathrm{~g} \\
\text { Prep Basis: As Received } \\
\text { Moisture(\%): NA } \\
\text { Result Units: pCi/g } \\
\text { File Name: } 041298008 \mathrm{E}\end{array}$} \\
\hline Library: USGS & & & & & \\
\hline CASNO & Target Nuclide & \multicolumn{2}{|c|}{ Result + +-2 s TPU } & MDC & Lab Qualifier \\
\hline $10045-97-3$ & Cs-137 & $-0.32+$ & & 1.00 & U \\
\hline
\end{tabular}

Comments:

\section{Qualifiers/Flags:}

$U$-Result is less than the sample specific MDC or less than the associated TPU

sQ - Spectral quality prevents accurate quantitation

Y1 - Chemical Yield is in control at 100-110\%. Quantiatve Yeld is assumed.

S1 - Nuclide identification andior quantitation is tentative.

Y2. Chemical Yeld outside defaut limits.

LT - Result is less than Requested MOC, greater than sample specific MDC.

MB - The requested MDC was not met, but the roported
activity is gronter then the reportod MDC.

$\mathrm{T}$ - Nuclide identification is tentative.

activity is groater then the reportod MOC.

R. Nuclide has exceeded 8 haltives.

$M$ - The requested MOC was not met.

Aboreviations:

TPU - Total Propagated Uncertainty (see PAI SOP 743)

MDC - Mnimum Detectable Concentration (see PAI SOP 709)

BOL - Below Detection Umit

Data Package ID: GSA0407061-1

Date Printed: Tuesday, August 24, 2004

Paragon Analytics

Page 9 of 10

LIMS Version: $5.054 \mathrm{~A}$

. 000019 


\section{Gamma Spectroscopy Results \\ PAI 713 Rev 8 \\ Sample Results}

Lab Name: Paragon Analytics

Work Order Number: 0407061

Client Name: ESH20_LANL

ClientProject ID: AREA G US Vegetation 7H02 C34A 3 A00 0009

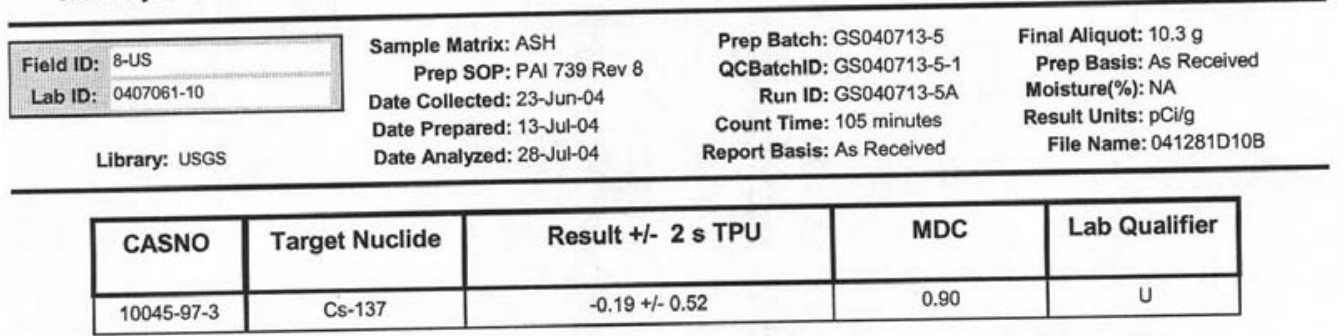

Qualifiers/Flags:

$U$ - Result is less than the sample specific MDC or less than the associated TPU

$Y 1$ - Chemical Yield is in control at 100-110\%. Quantitative Yield is assumed.

Y2-Chemical Yield outside default limits.

LT - Result is less than Roquested MDC, greater than sample specific MDC.

M3 - The requested MOC was not met. but the reported
activity is greater than the reported MDC.

$M$ - The requested MDC was not met.

Abbreviations:

TPU - Total Propagated Uncertainty (see PAI SOP 743)

MDC-Mnimum Detoctable Concentration (see PAI SOP 709)

BDL - Below Detection Limit

Data Package ID: GSA0407061-1
Paragon Analytics

LIMS Version: 5.054A
SQ - Spectral quallity prevents accurate quantitation.
S1 - Nuclide identification andior quantitaton is tentative.
TI- Nuclide identfication is tentative.
R- Nuclide has exceeded 8 halfives.
G. Sample density differs by more than $15 \%$ of LCS density.

Date Printed: Tuesday, August 24, 2004

Page 10 of 10 


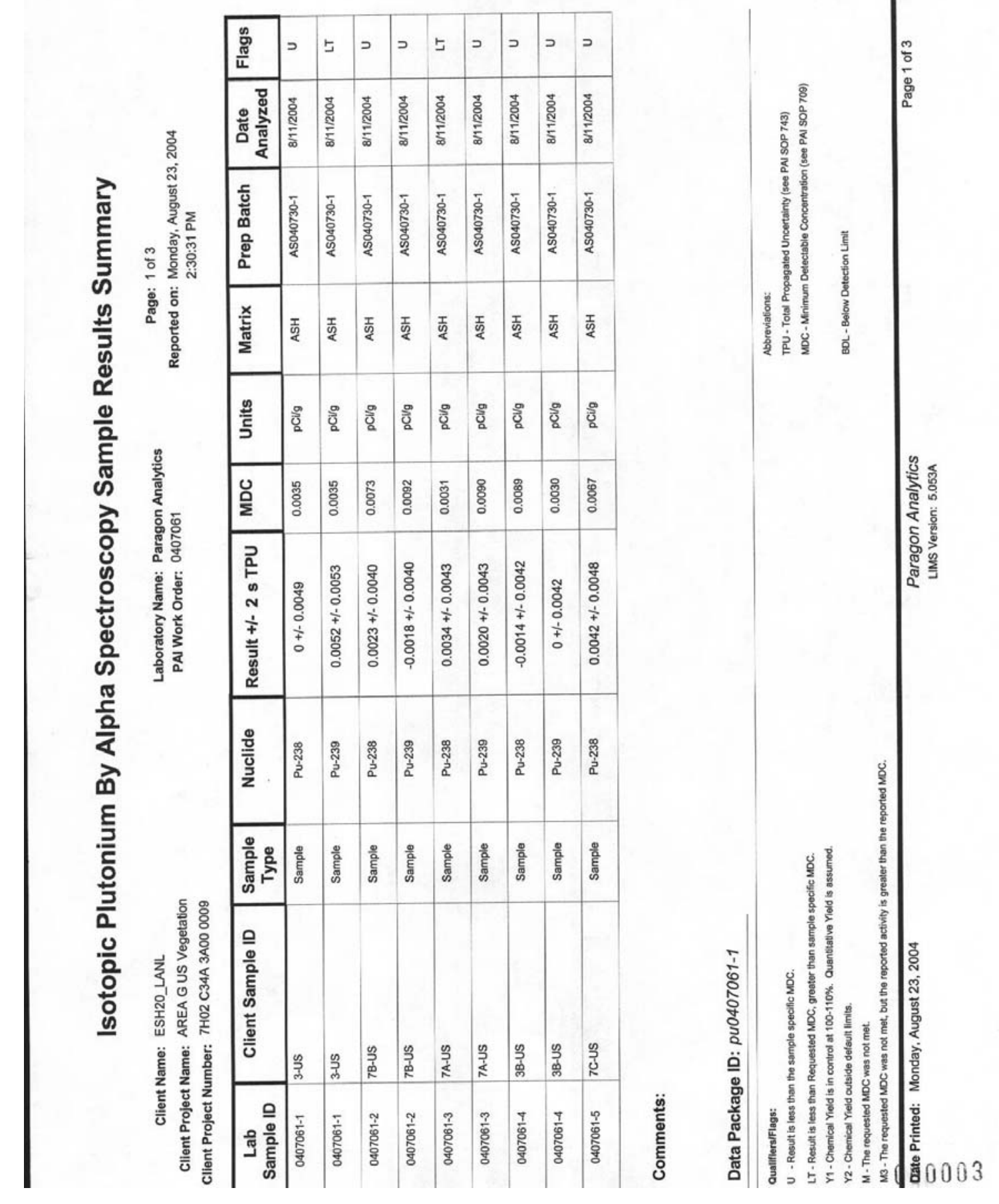




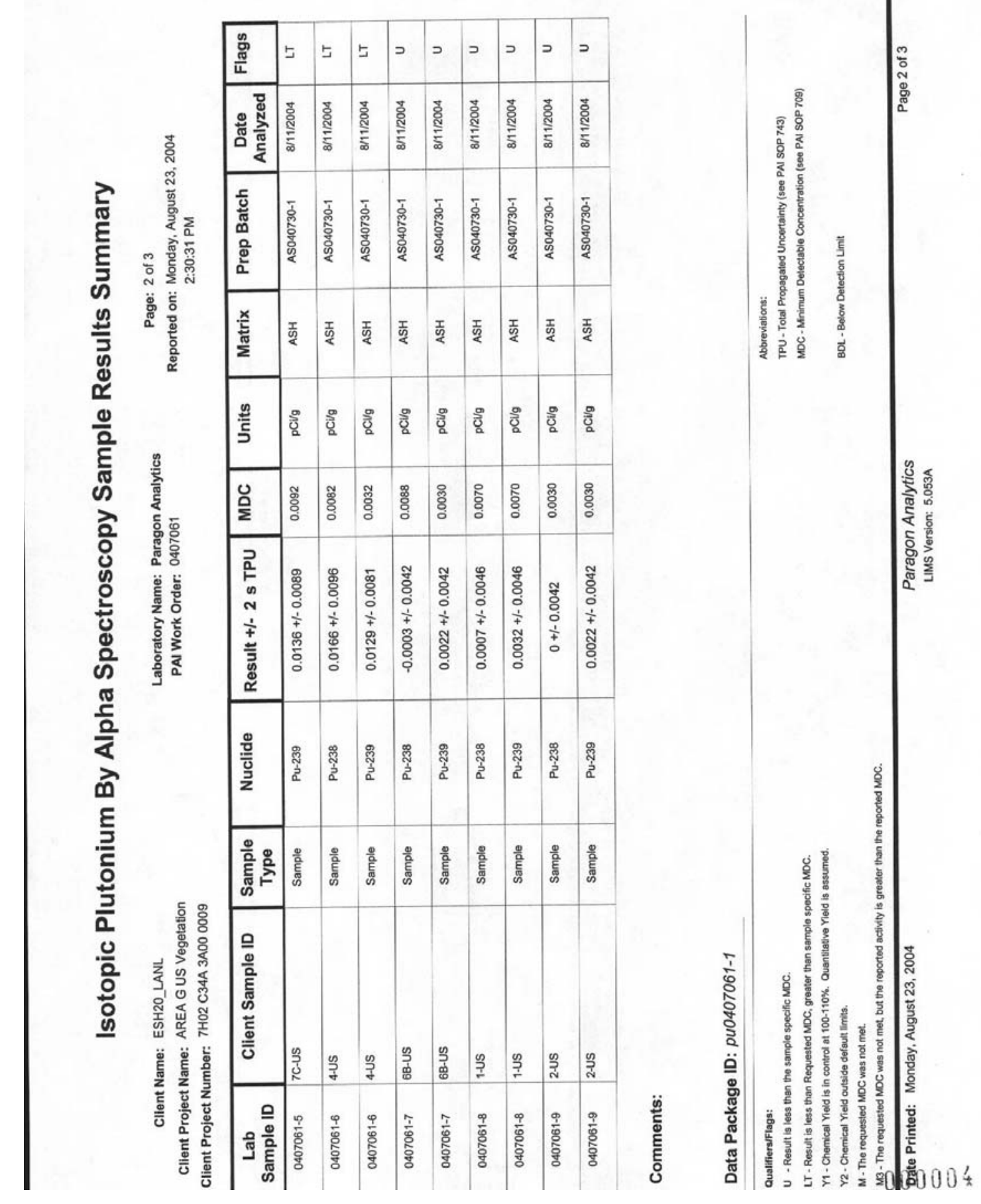



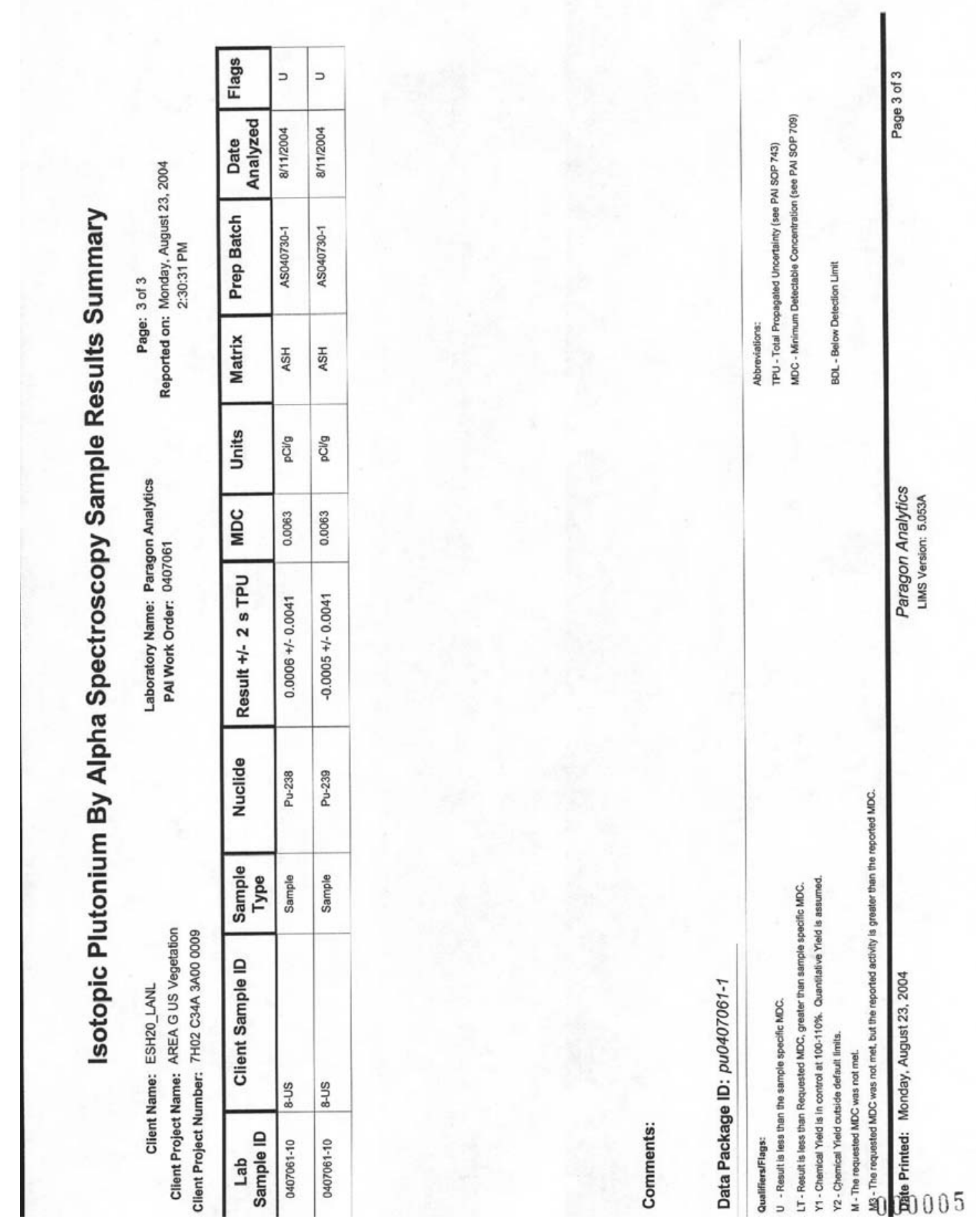


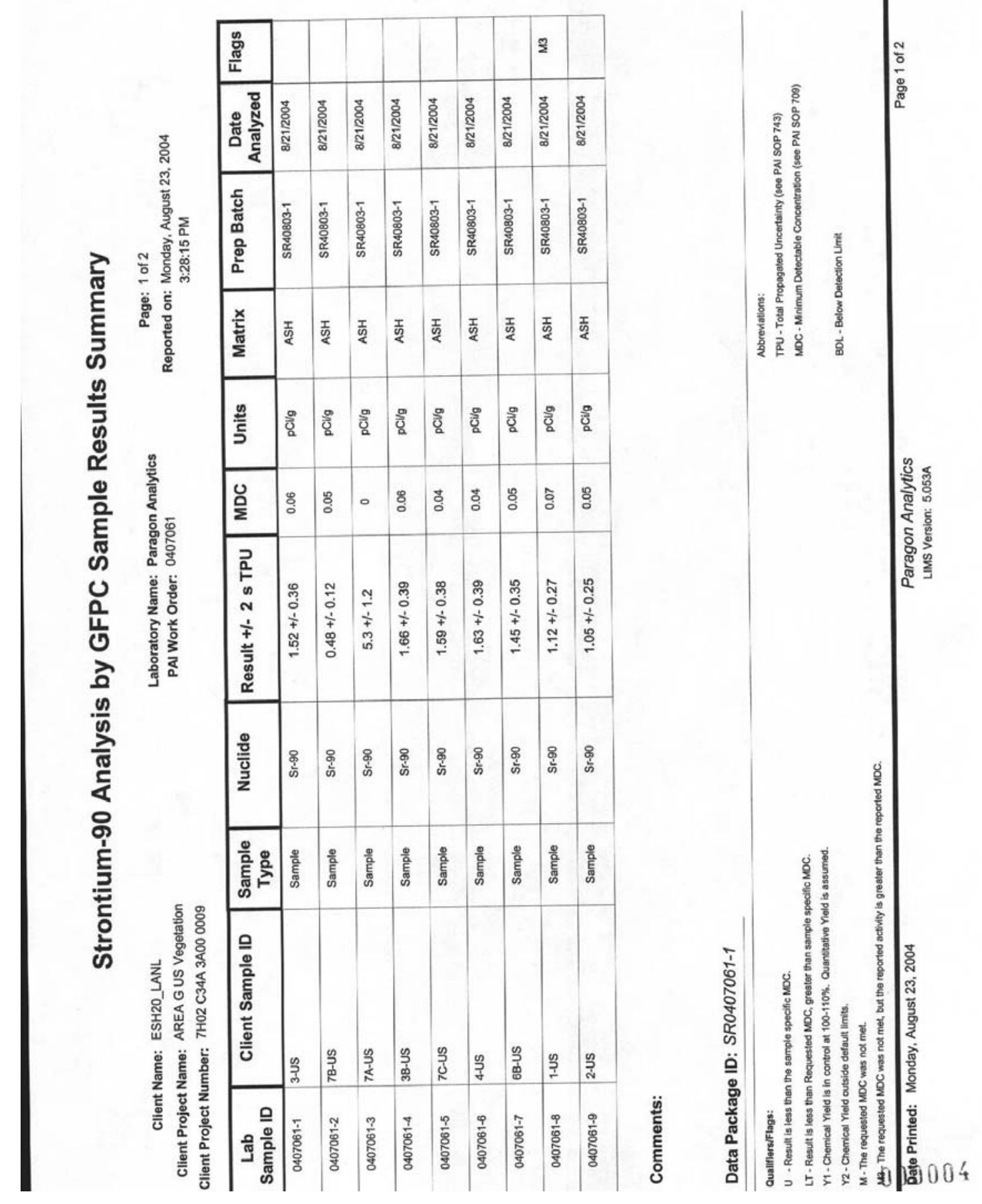



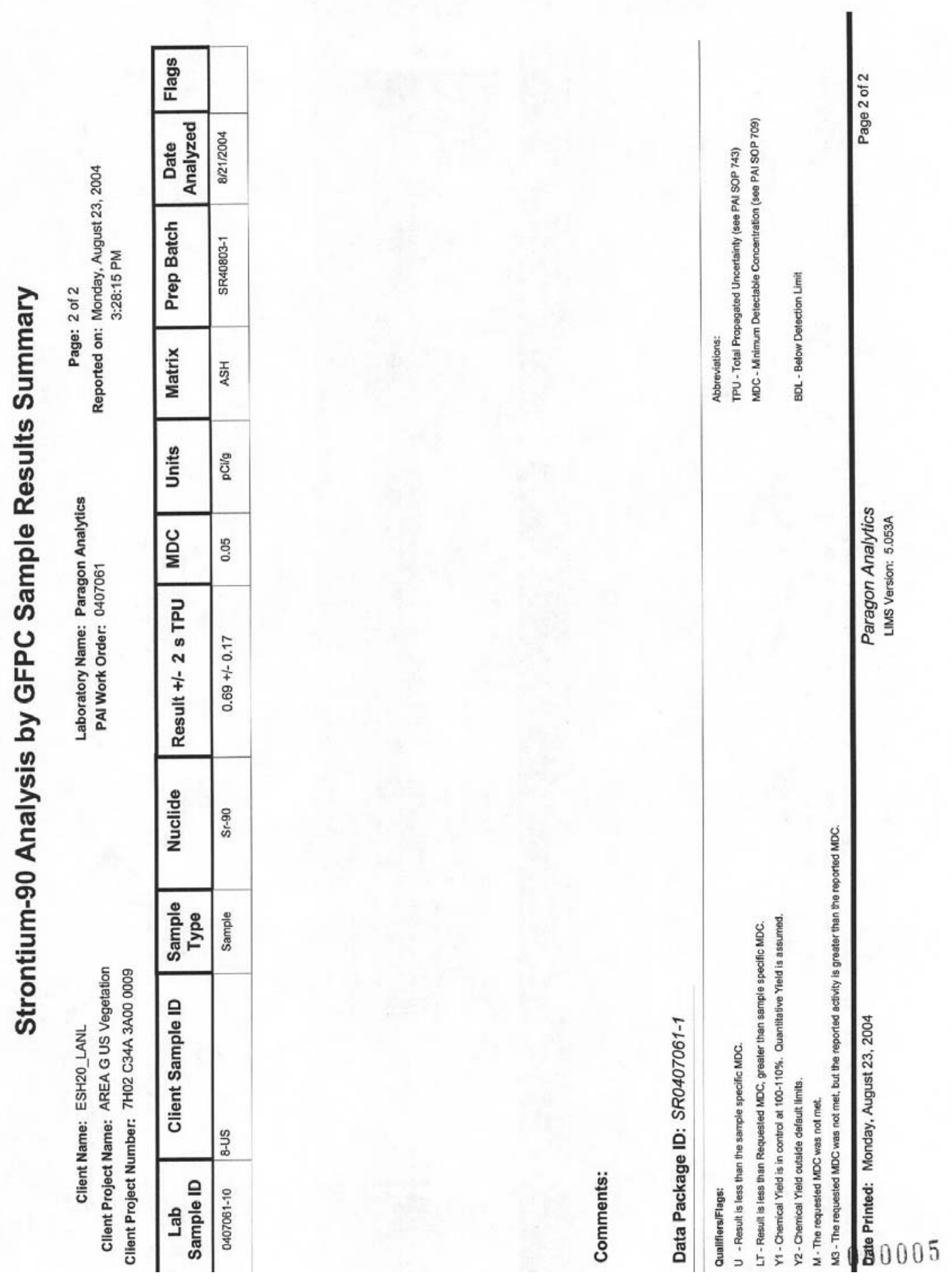

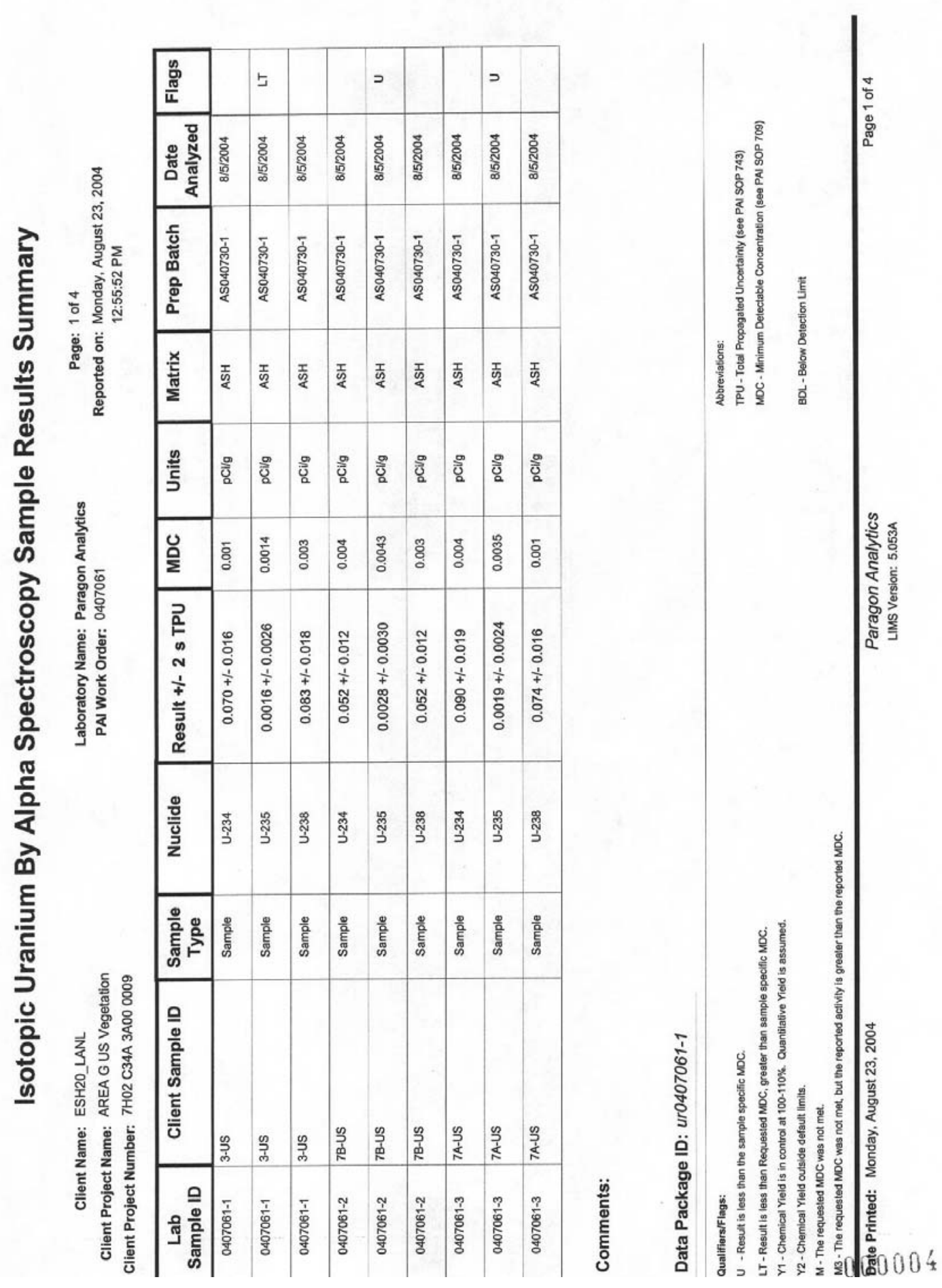


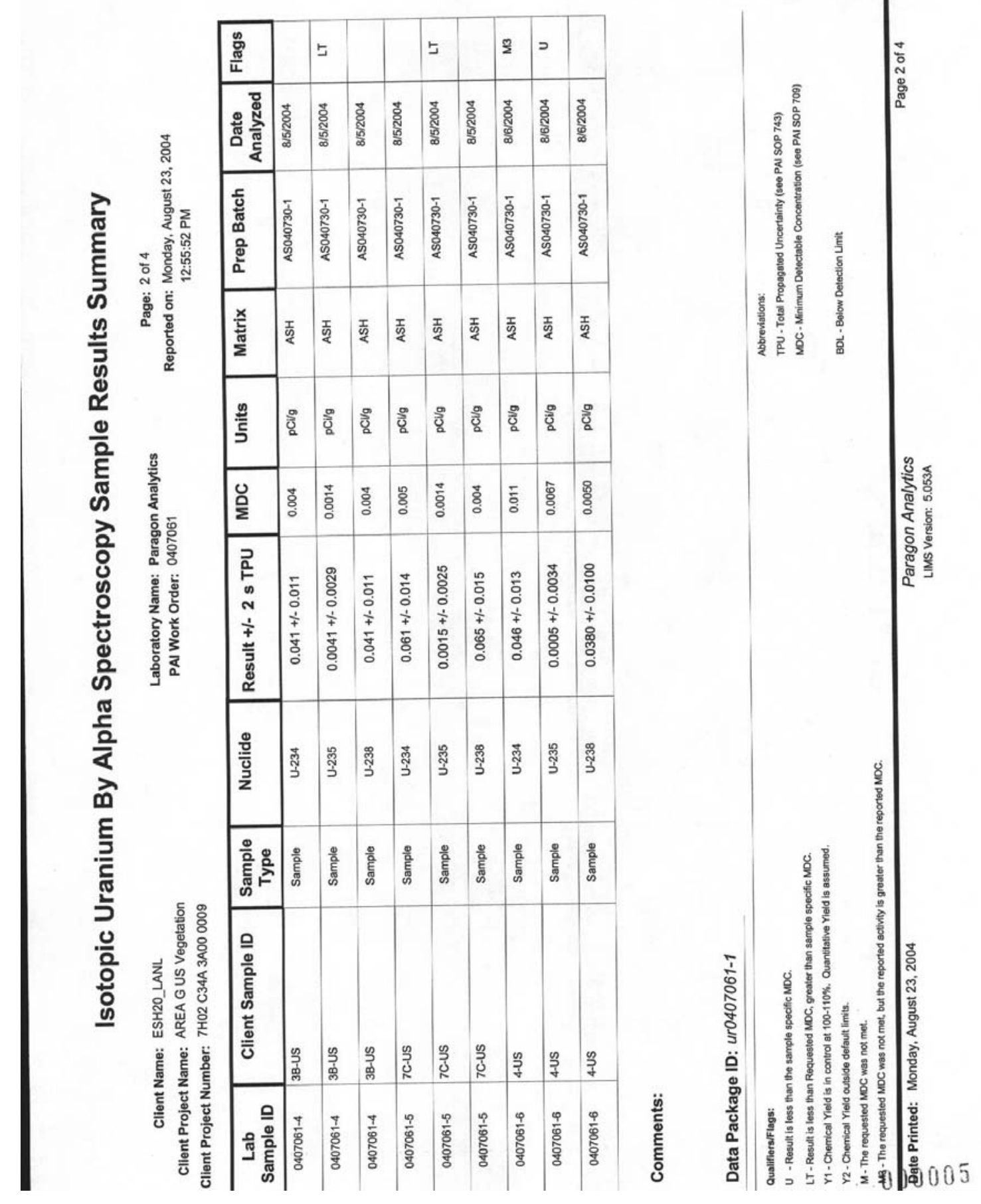



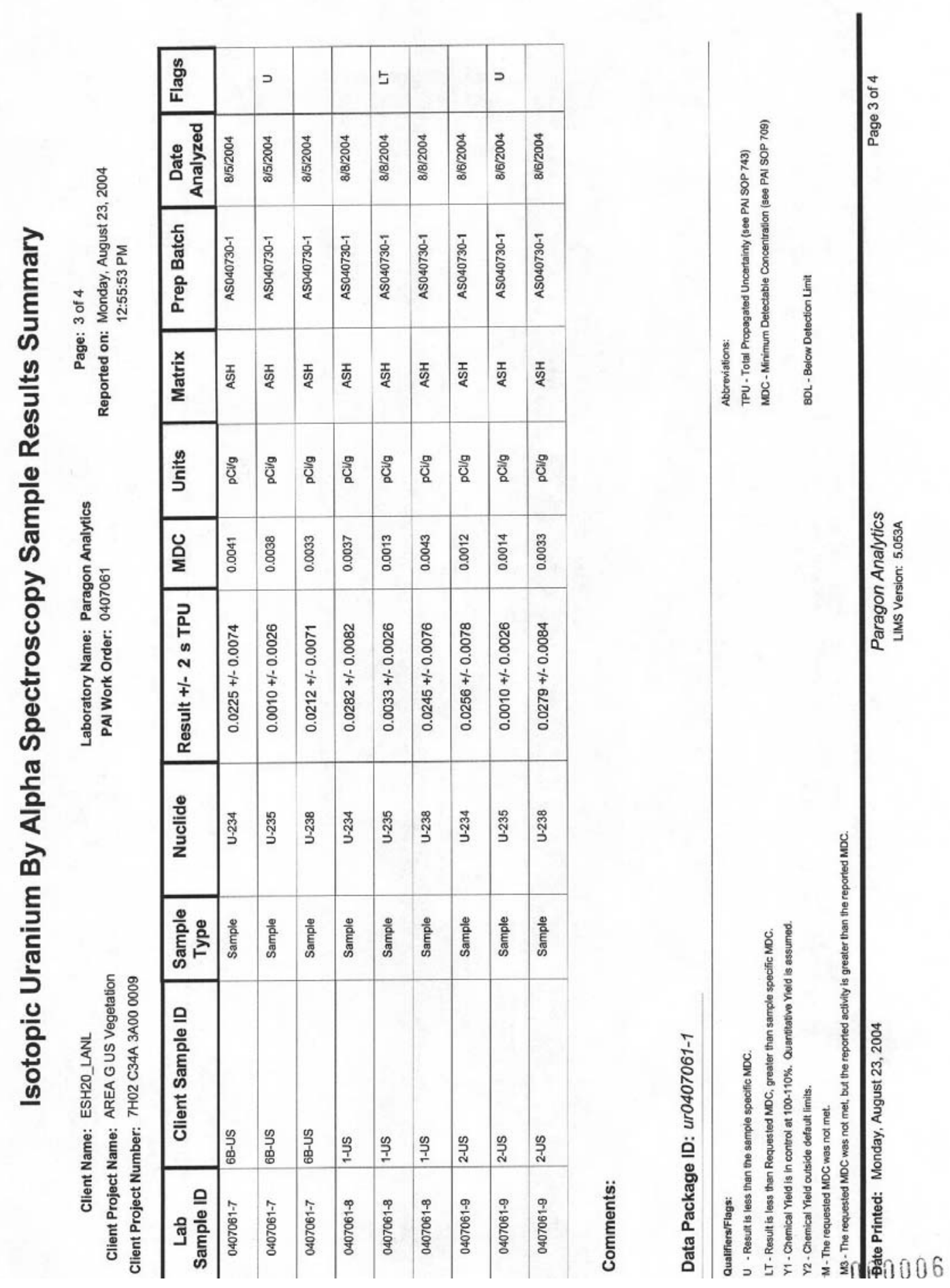

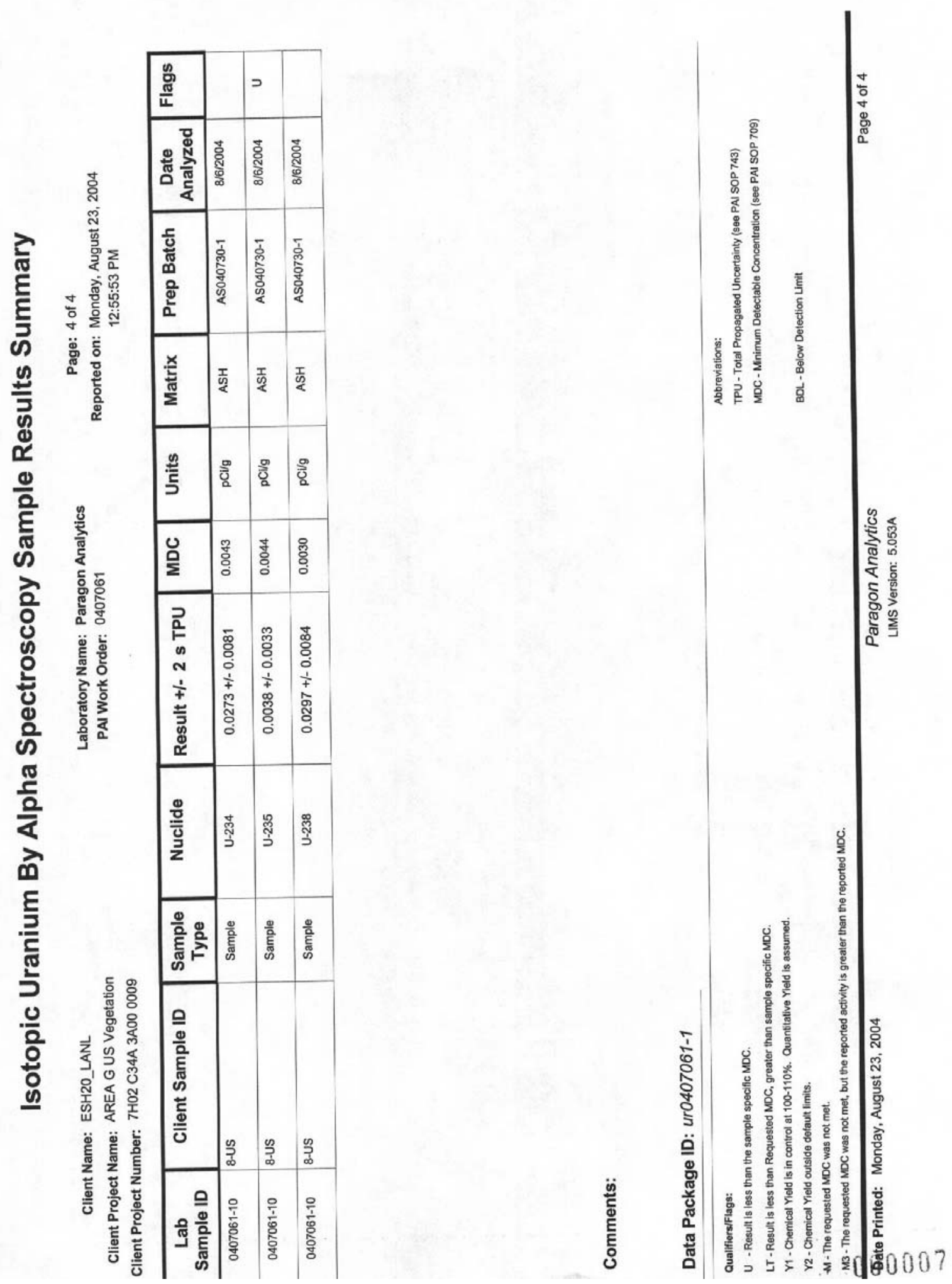
This report has been reproduced directly from the best available copy. It is available electronically on the Web (http://www.doe.gov/bridge).

Copies are available for sale to U.S. Department of Energy employees and contractors from:

Office of Scientific and Technical Information P.O. Box 62

Oak Ridge, TN 37831

(865) 576-8401

Copies are available for sale to the public from: National Technical Information Service

U.S. Department of Commerce

5285 Port Royal Road

Springfield, VA 22161

(800) 553-6847 


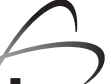

- Los Alamos

NATIONAL LABORATORY 